\title{
ASSESSMENT OF THE BEST AVAILABLE WASTEWATER MANAGEMENT TECHNIQUES FOR A TEXTILE MILL: \\ COST AND BENEFIT ANALYSIS
}

A THESIS SUBMITTED TO

THE GRADUATE SCHOOL OF NATURAL AND APPLIED SCIENCES OF MIDDLE EAST TECHNICAL UNIVERSITY

BY

BUĞÇE DOĞAN

IN PARTIAL FULFILMENT OF THE REQUIREMENTS FOR

THE DEGREE OF MASTER OF SCIENCE

IN

ENVIRONMENTAL ENGINEERING

SEPTEMBER 2008 
Approval of the thesis:

\section{ASSESSMENT OF THE BEST AVAILABLE WASTEWATER MANAGEMENT TECHNIQUES FOR A TEXTILE MILL: COST AND BENEFIT ANALYSIS}

submitted by BUĞÇE DOĞAN in partial fulfillment of the requirements for the degree of Master of Science in Environmental Engineering Department, Middle East Technical University by,

Prof. Dr. Canan Özgen

Dean, Gradute School of Natural and Applied Sciences

Prof. Dr. Göksel N. Demirer

Head of Department, Environmental Engineering

Prof. Dr. Ülkü Yetiş

Supervisor, Environmental Engineering Dept., METU

Dr. Merih Kerestecioğlu

Co-supervisor, COWI-SNS, Ankara

\section{Examining Committee Members:}

Prof. Dr. Aysel Atımtay

Environmental Engineering Dept., METU

Prof. Dr. Ülkü Yetiş

Environmental Engineering Dept., METU

Dr. Merih Kerestecioğlu

COWI-SNS, Ankara

Assoc. Prof. Dr. Ayşegül Aksoy

Environmental Engineering Dept., METU

Assoc. Prof. Dr. Mehmet Kitiş

Environmental Engineering Dept., SDU

Ahmet Beşler

Orta Anadolu Holding, Kayseri

Date: 
I hereby declare that all information in this document has been obtained and presented in accordance with academic rules and ethical conduct. I also declare that, as required by these rules and conduct, I have fully cited and referenced all material and results that are not original to this work.

Name, Last Name : Buğçe Doğan

Signature 


\author{
ABSTRACT \\ ASSESSMENT OF THE BEST AVAILABLE WASTEWATER MANAGEMENT \\ TECHNIQUES FOR A TEXTILE MILL: \\ COST AND BENEFIT ANALYSIS \\ Doğan, Buğçe \\ MSc., Department of Environmental Engineering \\ Supervisor : Prof. Dr. Ülkü Yetiş \\ Co-Supervisor: Dr. Merih Kerestecioğlu
}

September 2008, 180 pages

The Integrated Pollution Prevention and Control (IPPC) Directive from the European Union strives to achieve a high level of environmental protection by preventing or reducing the pollution emanating from industrial installations directly at the source. The Directive implies that the emission limit values should be set in accordance with each industry's Best Available Techniques (BAT). In the present study, water recovery and wastewater treatability alternatives developed beforehand were evaluated towards the evaluation of BATs for the management of wastewaters from a denim textile mill. For this purpose, an assessment that translates the key environmental aspects into a quantitative measure of environmental performance and also financial analysis were performed for each of the alternatives. The alternatives considered for water recovery from dyeing wastewaters were nanofiltration (NF) with coagulation and/or microfiltration $(\mathrm{MF})$ pretreatment, ozonation or peroxone and Fenton oxidation. On the other hand, for the end-of-pipe treatment of the mill's mixed wastewater; ozonation, Fenton oxidation, membrane bioreactor (MBR) and 
activated sludge process followed by membrane filtration technologies were evaluated. The results have indicated that membrane filtration process providing 70 $\%$ water recovery with the least environmental impacts is the BAT for water recovery. On the other side, MBR technology has appeared as the BAT for the endof-pipe treatment of the mill's mixed wastewater. A technical and financial comparison of these two BAT alternatives revealed that water recovery via membrane filtration from dyeing wastewaters is selected as the BAT for the water and wastewater management in the mill.

Keywords: BAT, Cross-media Effects, Cost-Benefit Analysis, IPPC Directive, Textile Industry. 


\title{
$\ddot{\mathbf{o z}}$
}

\section{TEKSTIIL ENDÜSTRİSİ İÇIN MEVCUT EN İYİ ATIKSU YÖNETIMM TEKNIKLERININ DEĞERLENDIRILMESİ: FAYDA VE MALIYYET ANALİİ}

\author{
Doğan, Buğçe \\ Yüksek Lisans, Çevre Mühendisliği Bölümü \\ Tez Yöneticisi : Prof. Dr. Ülkü Yetiş \\ Ortak Tez Yöneticisi : Dr. Merih Kerestecioğlu
}

Eylül 2008, 180 sayfa

Avrupa Birliği IPPC (Entegre Kirlilik Önleme ve Kontrolü) Direktifi, endüstri tesislerinden kaynaklanan kirliliği, kaynağında azaltarak ya da önleyerek, çevrenin yüksek seviyede korunmasını amaç edinmiştir. Direktif, tesisler için mevcut en iyi teknikler sayesinde emisyon limit değerlerini belirlemeyi gerektirmektedir. Mevcut çalışmada denim üreten bir tekstil fabrikasında oluşan atıksular için mevcut en iyi teknikleri belirlemek adına su geri kazanımı ve atıksu arıtılabilirlik alternatifleri geliştirilmiştir. $\mathrm{Bu}$ amaçla, her bir alternative için nicel bir çevresel performans değerlendirmesi ve alternatiflerin finansal analizleri yapılmıştır. Su geri kazanımı için düşünülmüş olan alternatifler boyama atıksuları için koagülasyon ya da mikrofiltrasyon (MF) ön arıtımıyla nanofiltrasyon (NF), ozonlama ve Fenton oksidasyonu iken; tesisin karışık atıksuyunun nihai bertarafi için uygulanmış olan alternatifler ozonlama, Fenton oksidasyonu, membran biyoreaktörü (MBR) ve aktif çamur sonrasında membran filtrasyon prosesleridir. Sonuçlar, su geri kazanımı çalışmaları için \% 70 su geri kazanımı sağlamış olan en az çevresel etkisi olan 
membran filtrasyon prosesini mevcut en iyi teknik olarak göstermektedir. Diğer taraftan membran biyoreaktör prosesi tesisteki karışık atıksuyun arıtılması için mevcut en iyi teknik olarak görülmektedir. Belirlenmiş olan alternatiflerin teknik ve ekonomik değerlendirilmesi sonucunda, membran filtrasyon prosesi ile boyama atıksularından su geri kazanımı, tesisin su ve atıksu yönetimi açısından mevcut en iyi alternatif olarak seçilmiştir.

Anahtar Kelimeler: BAT, Çapraz-ortam Etkileri, Fayda-Maliyet Analizi, IPPC Direktifi, Tekstil Endüstrisi. 
to my beloved family 


\section{ACKNOWLEDGEMENTS}

I would like to express my warmest gratitude to my supervisor Prof. Dr. Ülkü Yetiş for her endless supervision, trust, guidance and encouragement during and beyond this work. Without her vision and support, I could never complete this work. It is a great honour for me to be a student of Dr. Yetiş.

I also wish to express my deepest gratitude to my co-supervisor Dr. Merih Kerestecioğlu for his guidance, excitement, advice and support throughout this thesis study.

I also would like to acknowledge the valuable comments and contributions of my Supervising Committee Members.

My special thanks are extended to my colleagues Hümeyra Bahçeci, A. Hakan Balman, Ahmet Doğan, B. Fuat Çankaya, and Ersin Yıldırım for their friendship, support, positive energy and joy.

I am also thankful for support, motivation and sisterhood of my cousin Didem Arıkan...

Finally, my deepest thanks are dedicated to Mom and Dad. They were always near me with their encouragement and their support. And lastly, but not least, I would like to express my warmest thanks and love to my dear A. Güray Çimentepe for his endless trust, endless support and encouragement. I could never complete this thesis without him... 


\section{TABLE OF CONTENTS}

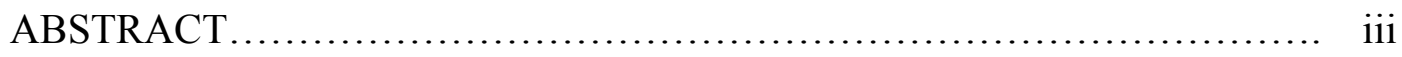

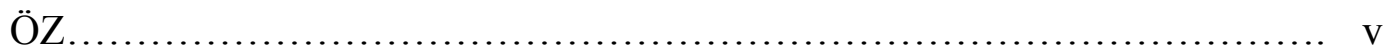

ACKNOWLEDGEMENTS ........................................... viii

TABLE OF CONTENTS ............................................... ix

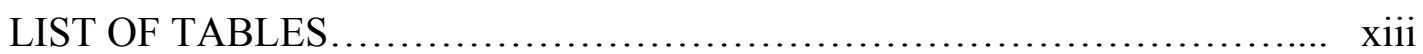

LIST OF FIGURES............................................. xviii

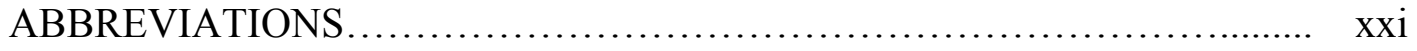

CHAPTERS

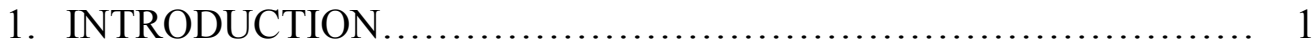

1.1. General................................................... 1

1.2. Objective and Scope of the Study........................... 3

1.3. Thesis Overview........................................ 4

2. LITERATURE REVIEW ................................... 5

2.1. Investment and Operating Cost Data for Alternative Technologies 5

2.1.1. Activated Sludge Process Costs.................... 5

2.1.2. Advanced Oxidation Processes........................ 11

2.1.2.1. Ozonation Costs............................. 12

2.1.2.2. Fenton Oxidation Costs....................... 15

2.1.2.3. Peroxone Process Costs....................... 18

2.1.3. Membrane Processes................................. 19

2.1.3.1. $\quad$ MBR Costs ............................... 20

2.1.3.2. Membrane Filtration Costs................... 23

3. LEGISLATION BACKGROUND ............................. 27

3.1. Integrated Pollution Prevention and Control Directive............ 27 
3.1.1. Reference Document on Economics \& Cross-Media Effects........................................... 31

3.1.1.1. General Information......................... 31

3.1.1.2. Cross-Media Guidelines..................... 33

3.1.1.3. Costing Methodology....................... 36

3.1.1.4. Evaluation of the Alternatives................. 41

3.1.1.5. Economic Viability of the Sector.............. 44

4. SELECTED MILL................................................ 47

4.1. Water Recovery Studies.................................... 50

4.1.1. Coagulation as a Pre-treatment for Dyeing Wastewaters 50

4.1.2. Membrane Filtration for Dyeing Wastewaters.......... 52

4.1.3. Ozonation for Dyeing Wastewaters.................. 53

4.1.4. Fenton Oxidation for Dyeing Wastewaters............. 55

4.2. Prioritization of Applicable Water Recovery Alternatives........ 56

4.3. Wastewater Treatability Studies................................ 59

4.3.1. Biological Treatment Followed by MF and NF for Mixed Wastewaters.............................................. 59

4.3.2. Membrane Bioreactor for Mixed Wastewaters........... 61

4.3.3. Ozonation for Mixed Wastewaters.................... 63

4.3.4. Fenton Oxidation for Mixed Wastewaters.............. 65

4.4. Prioritization of Applicable Wastewater Treatability Alternatives.. 65

5. COST AND BENEFIT ANALYSIS .............................. 68

5.1. Assumptions............................................... 68

5.2. Analysis of Water Recovery Studies........................ 70

5.2.1. Environmental Impact Analysis.................... 71

5.2.1.1. Identification of Alternatives.................. 71

5.2.1.2. Inventory of Consumptions and Emissions...... 72

5.2.1.3. Cross-media Effects of the Alternatives.......... 76

5.2.2. Financial Analysis............................... 84 
5.2.2.1. Investment Costs............................ 84

5.2.2.2. Operating Costs.............................. 88

5.2.2.3. Revenues and Avoided Costs.................. 92

5.2.2.4. Net Present Value............................ 95

5.2.2.5. Internal Rate of Return...................... 96

5.2.2.6. Annual Cost Calculation......................... 97

5.2.3. Evaluation of the Water Recovery Alternatives.......... 98

5.2.3.1. Cost Effectiveness and Benefit Analysis......... 98

5.3. Analysis of Wastewater Treatability Studies................... 100

5.3.1. Environmental Impact Analysis.................... 100

5.3.1.1. Identification of Alternatives................ 100

5.3.1.2. Inventory of Consumptions and Emissions...... 101

5.3.1.3. Cross-media Effects of the Alternatives.......... 105

5.3.2. Financial Analysis................................. 108

5.3.2.1. Investment Costs........................... 108

5.3.2.2. Operating Costs............................. 113

5.3.2.3. Revenues and Avoided Costs.................. 121

5.3.2.4. Net Present Value............................ 127

5.3.2.5. Internal Rate of Return...................... 127

5.3.2.6. Annual Cost Calculation......................... 128

5.3.3. Evaluation of the Wastewater Treatability Alternatives... 129

5.3.3.1. Cost Effectiveness and Benefit Analysis.......... 129

5.4. Sensitivity Analysis...................................... 131

5.5. Risk Evaluation........................................ 134

5.6. Economic Viability of the Textile Sector.................... 136

6. SUMMARY .................................................. 138

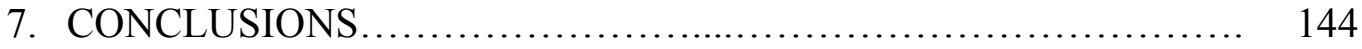

8. RECOMMENDATIONS ........................................ 146

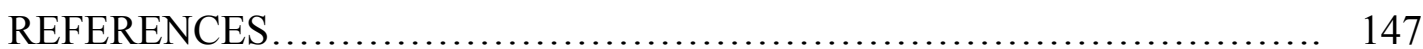




\section{APPENDICES}

APPENDIX A. Wastewater Reuse Standards........................ 155

APPENDIX B. Design Criteria of the Existing Wastewater Treatment Plant............................................. 156

APPENDIX C. Sample Working Sheets............................. 157

APPENDIX D. Sensitivity Diagrams.............................. 162

APPENDIX E. Sensitivity Analysis Results......................... 174

APPENDIX F. Calculations for Summary Tables...................... 179 


\section{LIST OF TABLES}

\section{TABLES}

Table 2.1. Flowrate and COD concentrations of wastewater A, B, and C from a textile mill in Turkey............................................. 9

Table 2.2. Unit investment and operating costs for different flowrates........ 11

Table 2.3. Unit investment and operating costs for different COD concentrations.................................................... 11

Table 2.4. Ferric sulfate and hydrogen peroxide unit costs................. 17

Table 2.5. Fenton oxidation process - Typical operating costs............... 18

Table 2.6. MBR System Costs........................................ 22

Table 2.7. Investment and running costs for MF, UF, and NF.............. 25

Table 2.8. Investment cost formulas for membrane filtration processes........ 26

Table 3.1. The Scale Exponent Method................................. 40

Table 4.1. General characteristics for wastewaters of the most-widely used recipes

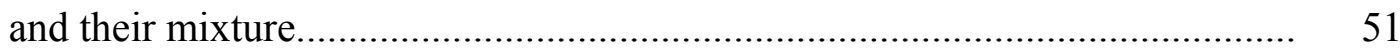

Table 4.2. Coagulation experiments results............................................... 51

Table 4.3. General characteristics for wastewaters from the first post-rinsing stage and composite wastewaters from all post-rinsing stage................................ 52

Table 4.4. COD and color removal from the first post-rinsing stage and composite wastewaters from all post-rinsing stage, and most-widely used recipes.......... 53

Table 4.5. General characteristics for wastewaters subjected to ozonation process

Table 4.6. COD and color removal from wastewaters subjected to ozonation process.

Table 4.7. General characteristics for wastewaters subjected to Fenton oxidation process 
Table 4.8. Summary for water recovery alternatives.................................... 56

Table 4.9. Prioritization of water recovery alternatives-Estimated Scores....... 58

Table 4.10. Discharge standards of KASKI.................................................. 60

Table 4.11. General characteristics for wastewaters subjected to biological treatment followed by MF and NF........................................................................... 61

Table 4.12. General characteristics of the influent wastewater to the pilot-scale MBR

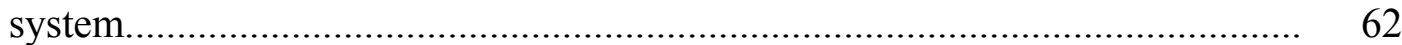

Table 4.13. The performance of the MBR system......................................... 62

Table 4.14. General characteristics for wastewaters subjected to ozonation and

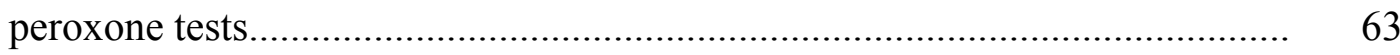

Table 4.15. COD and color removal from wastewaters subjected to ozonation and

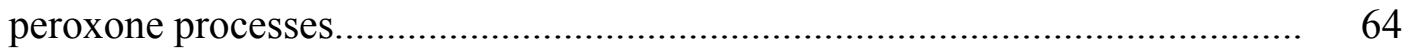

Table 4.16. General characteristics for wastewaters subjected to post-ozonation...

Table 4.17. COD and color removal from wastewaters subjected to post

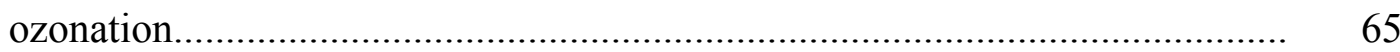

Table 4.18. Summary for wastewater treatability alternatives........................ 66

Table 5.1. General characteristics of the wastewaters used during the cost-benefit

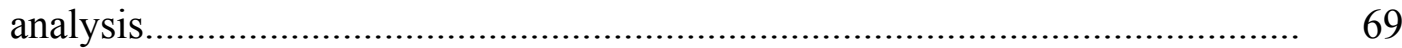

Table 5.2. Wastewater distribution among the process streams...................... $\quad 70$

Table 5.3. Identification of the water recovery alternatives............................ 71

Table 5.4. Energy consumptions of the water recovery alternatives................. 72

Table 5.5. Average fuel use and emissions released to create $1 \mathrm{GJ}$ of

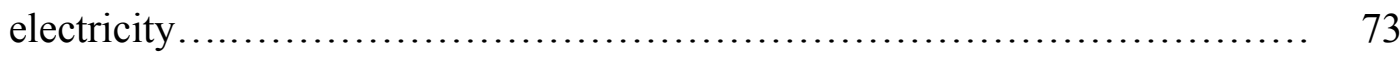

Table 5.6. Calculated emission values released from the alternative options... 74

Table 5.7. Mass of pollutants released to air..................................................... 74

Table 5.8. Hazardous waste generation for the water recovery alternatives...... 76

Table 5.9. Human toxicity potentials of the water recovery alternatives........... 77

Table 5.10. Global warming potentials of the water recovery alternatives........ 79 
Table 5.11. Acidification potentials of the water recovery alternatives

Table 5.12. Photochemical ozone creation potentials of the water recovery alternatives

Table 5.13. Cross-media effects of the water recovery alternatives................... 83

Table 5.14. Investment costs for NF process................................................ 85

Table 5.15. Investment costs of the water recovery alternatives...................... 87

Table 5.16. Operating costs for NF application............................................... 89

Table 5.17. Operating costs for MF application................................................ 90

Table 5.18. Operating costs for ozonation application..................................... 91

Table 5.19. Operating costs of the water recovery alternatives....................... 92

Table 5.20. Cash flow assessment for membrane filtration alternative............ 93

Table 5.21. Cash flow assessment for ozonation alternative........................... 94

Table 5.22. NPV values of the water recovery alternatives............................ 96

Table 5.23. IRR values of the water recovery alternatives.............................. 97

Table 5.24. Annual costs of the water recovery alternatives............................ 98

Table 5.25. Cost effectiveness of the water recovery alternatives.................. 99

Table 5.26. Identification of the wastewater treatability alternatives................ 101

Table 5.27. Specific energy consumptions of treatment alternatives................. 102

Table 5.28. Electricity usage of treatment alternatives.................................... 102

Table 5.29. Calculated emission values released from the treatment alternative options

Table 5.30. Mass of pollutants released to air due to treatment alternatives.....

Table 5.31. Mass of pollutants released to aquatic environment of treatability

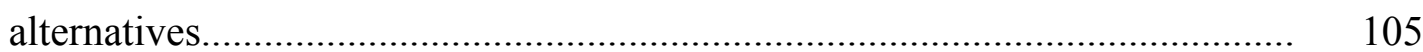

Table 5.32. Hazardous waste amounts of the treatability alternatives............... 105

Table 5.33. Cross-media effects of the wastewater treatability alternatives...... 107

Table 5.34. Investment costs for MF and NF process for treatability alternatives

Table 5.35. Investment costs for MBR process 
Table 5.36. Investment costs of treatability alternatives.

Table 5.37. Operating costs for existing activated sludge system of the textile mill

Table 5.38. Unit operating costs for existing activated sludge system of the textile mill

Table 5.39. Operating costs for MF + NF application.

Table 5.40. Operating costs for MBR application

Table 5.41. Operating costs for ozonation application before activated sludge system.

Table 5.42. Operating costs for peroxone treatment before activated sludge system.

Table 5.43. Operating costs for ozonation application after activated sludge system.

Table 5.44. Operating costs of the wastewater treatability alternatives.

Table 5.45. Cash flow assessment for activated sludge and membrane filtration alternative.

Table 5.46. Cash flow assessment for membrane bioreactor alternative.

Table 5.47. Cash flow assessment for activated sludge with pre-ozonation alternative

Table 5.48. Cash flow assessment for activated sludge with peroxone alternative.

Table 5.49. Cash flow assessment for ozonation after activated sludge alternative.

Table 5.50. NPV values of the wastewater treatability alternatives.

Table 5.51. IRR values of the wastewater treatability alternatives

Table 5.52. Annual costs of the wastewater treatability alternatives

Table 5.53. Cost effectiveness of the wastewater treatability alternatives.

Table 5.54. COD and color concentrations for sensitivity analysis.... 
Table 6.1. Summary of cross-media effects for the selected BATs.

Table 6.2. Summary of financial analysis for the selected BATs................... 141

Table A.1. Wastewater reuse criteria............................................................... 155

Table B.1. Design criteria of the existing wastewater treatment plant in the textile mill.

Table E.1. Changes in costs when critical variables change for water recovery alternatives.

Table E.2. Changes in costs when critical variables change for wastewater treatability alternatives. 


\section{LIST OF FIGURES}

\section{FIGURES}

Figure 2.1. Unit investment cost versus wastewater flowrate graph for activated sludge systems existing in some of the textile mills located in Turkey.......... 7 Figure 2.2. Relationship between unit investment cost and COD removed from activated sludge processes existing in some textile mills of Turkey........... 8 Figure 2.3. Relationship between unit operating cost and wastewater flowrate for activated sludge processes existing in some textile mills of Turkey........... 8

Figure 2.4. The price of the main equipment for ozonation treatment.......... 15

Figure 2.5. MBR operating cost change............................. 23

Figure 3.1. Chart for cross-media guidelines.......................... 34

Figure 3.2. Chart for costing methodology .......................... 37

Figure 3.3. Chart for evaluating the alternatives......................... 42

Figure 3.4. Decision making process for evaluating cost effectiveness........ 43

Figure 3.5. Evaluation of economic viability in the sector................. 45

Figure 4.1. Water flow in the selected mill............................ 49

Figure 6.1. Investment cost sensitivity diagram for $\mathrm{MF}+\mathrm{NF}$ alternative applied in water recovery studies........................................... 143

Figure 6.2. Investment cost sensitivity diagram for the MBR alternative applied in wastewater treatability studies...................................... 143

Figure C.1. Input page for sensitivity analysis................................................ 158

Figure C.2. Working sheet of cross-media assessment for water recovery

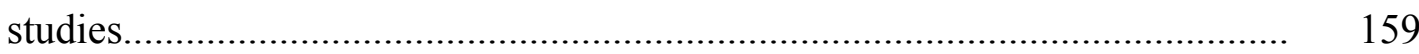

Figure C.3. Working sheet of financial analysis for water recovery studies...... 160

Figure C.4. Working sheet for ozonation cost calculations............................. 161 
Figure D.1. Investment cost sensitivity diagram for MF + NF alternative applied in water recovery studies.

Figure D.2. Operating cost sensitivity diagram for $\mathrm{MF}+\mathrm{NF}$ alternative applied in water recovery studies.

Figure D.3. NPV sensitivity diagram for MF + NF alternative applied in water recovery studies

Figure D.4. Investment cost sensitivity diagram for ozonation alternative applied in water recovery studies.

Figure D.5. Operating cost sensitivity diagram for ozonation alternative applied in water recovery studies.

Figure D.6. NPV sensitivity diagram for ozonation alternative applied in water recovery studies

Figure D.7. Investment cost sensitivity diagram for the AS $+\mathrm{MF}+\mathrm{NF}$ alternative applied in wastewater treatability studies

Figure D.8. Operating cost sensitivity diagram for the AS + MF + NF alternative applied in wastewater treatability studies

Figure D.9. NPV sensitivity diagram for the AS + MF + NF alternative applied in wastewater treatability studies

Figure D.10. Investment cost sensitivity diagram for the MBR alternative applied in wastewater treatability studies

Figure D.11. Operating cost sensitivity diagram for the MBR alternative applied in wastewater treatability studies.

Figure D.12. NPV sensitivity diagram for the MBR alternative applied in wastewater treatability studies. 168

Figure D.13. Investment cost sensitivity diagram for the ozonation + AS alternative applied in wastewater treatability studies 169

Figure D.14. Operating cost sensitivity diagram for the ozonation + AS alternative applied in wastewater treatability studies 
Figure D.15. NPV sensitivity diagram for the ozonation + AS alternative applied in wastewater treatability studies.....

Figure D.16. Investment cost sensitivity diagram for the peroxone + AS alternative applied in wastewater treatability studies

Figure D.17. Operating cost sensitivity diagram for the peroxone + AS alternative applied in wastewater treatability studies

Figure D.18. NPV sensitivity diagram for the peroxone + AS alternative applied in wastewater treatability studies.

Figure D.19. Investment cost sensitivity diagram for the post ozonation alternative applied in wastewater treatability studies

Figure D.20. Operating cost sensitivity diagram for the post ozonation alternative applied in wastewater treatability studies.

Figure D.21. NPV sensitivity diagram for the post ozonation alternative applied in wastewater treatability studies

Figure F.1. Cross-media effects of the existing activated sludge system in the mill. 


\section{LIST OF ABBREVIATIONS}

$\begin{array}{ll}\text { BAT } & \text { Best Available Techniques } \\ \text { BREF } & \text { BAT Reference Document } \\ \text { COD } & \text { Chemical Oxygen Demand } \\ \text { EU } & \text { European Union } \\ \text { EUR } & \text { European Euro } \\ \text { EWA } & \text { European Water Association } \\ \text { IPPC } & \text { Integrated Pollution Prevention and Control } \\ \text { IRR } & \text { Internal Rate of Return } \\ \text { KASKI } & \text { KayseriWater and Sewerage Directorate } \\ \text { LCA } & \text { Life Cycle Assessment } \\ \text { MBR } & \text { Membrane Bioreactor } \\ \text { METU } & \text { Middle East Technical University } \\ \text { MF } & \text { Microfiltration } \\ \text { MoEF } & \text { Ministry of Environment and Forestry } \\ \text { NF } & \text { Nanofiltration } \\ \text { NPV } & \text { Net Present Value } \\ \text { RO } & \text { Reverse osmos } \\ \text { UF } & \text { Ultrafiltration } \\ \text { USD } & \text { United States Dollars } \\ \text { YTL } & \text { New Turkish Liras }\end{array}$




\section{CHAPTER 1}

\section{INTRODUCTION}

\subsection{General}

The European Union (EU) has a set of common rules specified in the Integrated Pollution Prevention and Control (IPPC) Directive (96/61/EC), published in 1996, for permitting industrial installations being found in the EU Member States. The aim of this Directive is to develop an integrated approach in order to improve the management and control of industrial facilities so as to achieve a high level of environmental protection taking into account the emissions in air, water and soil as a whole.

According to Article 3 of the Directive, "Member States shall take the necessary measures to provide that the competent authorities ensure that installations are operated in such a way that all the appropriate preventive measures are taken against pollution, in particular through application of the Best Available Techniques (BAT)" [1]. In this context, within the definition of "available", the Directive states that "techniques shall mean those developed on a scale which allows implementation in the relevant industrial sector, under economically and technically viable conditions, taking into consideration the costs and advantages" [1]. Moreover, there is a requirement that in the determination of BAT, the technical characteristics of the installation concerned, its geographical location and the local environmental conditions should be taken into account. 
Under the framework of the IPPC Directive, a Reference Document called as "Economics and Cross-Media Effects" has been developed in order to reinforce the determination of BAT by setting methodologies. In this Reference Document, while determining the BAT for the installation concerned, first step that should be taken into consideration is the environmental effects of the options, namely "Cross-Media Effects". The purpose of the cross-media methodology is to provide guidance for how to choose the best alternative [2]. Secondly, costing methodology is mentioned in order to determine the cost for each option considered. After the establishments of cross-media effects and costs of the options, their comparison is needed in order to determine which of the alternative can be selected to be BAT. According to the abovementioned definition of "available" stated in the Directive, alternatives that are designated to be BAT should be ones that are technically and economically viable for the implementation in the relevant industrial installations. Therefore, at the end of the cost-benefit analysis, economic viability in the sector needs to be considered taking into account industrial structure, market structure, and resilience of the sector.

Textile industry is one of activities listed in the Annex 1 of the IPPC Directive. The Directive covers only "plants for pretreatment (operations such as washing, bleaching, and mercerization) or dyeing of fibres or textiles where the treatment capacity exceeds 10 tones per day", not the entire textile processes. According to the Directive-Specific Plan for the IPPC Directive, published by the Ministry of Environment and Forestry of Turkey in 2005, there exist approximately $240-300$ textile companies that should be considered within the IPPC Directive. In this report, costs for implementation of environmental management systems in the textile industry were forecasted on average 15,000 EUR - 20,000 EUR per installations. In addition, total costs for the implementation of such systems in the textile industries operating whole through Turkey were estimated as 3.6 - 6.0 million EUR [3]. 


\subsection{Objective and Scope of the Study}

The major aim of this thesis is to select the best water and wastewater management scheme under economically and technically viable conditions taking into consideration the costs and advantages for a selected textile mill in Turkey. The study is a part of the TUBITAK financed project entitled as "Adaptation of IPPC Directive to a Textile Mill in Turkey" which is conducted by the Department of Environmental Engineering at the Middle East Technical University (METU) in cooperation with the Ministry of Environment and Forestry of Turkey.

A denim producing mill had been chosen for the adaption of IPPC Directive. Many water and wastewater management alternatives such as water recovery techniques and wastewater treatability technologies were studied and technically discussed for the purpose of the project. In the present study, initially, environmental impacts of each management alternative were determined within the framework of cross-media guidelines specified in the Reference Document on "Economics and Cross-Media Effects". Then, financial analysis including investment and operational costs of the alternative water and wastewater management techniques identified in the previous phases of the project was performed according to the costing methodology indicated in the abovementioned Reference Document. In addition, sensitivity analysis was performed for the critical variations that affect the financial analysis.

As a result of the assessments mentioned above, whether the alternatives studied for water management and the ones for wastewater management are BAT or not was determined in this thesis study by means of cost-benefit analysis. Consequently, the best economically and technically viable alternative for water and wastewater management was selected as the BAT for the whole system. 


\subsection{Thesis Overview}

This thesis includes seven chapters. Chapter 1 (Introduction) presents mainly the objective and the scope of the study. In Chapter 2 (Literature Review), investment and operating cost data for the alternative technologies were introduced. Chapter 3 (Legislation Background) reviews the fundamentals of the IPPC Directive and the "Reference Document on Economics and Cross-Media Effects". In Chapter 4 (Selected Mill), the studies having done throughout this project are detailed. Also presented in this chapter is the screening of the alternatives for the cost-benefit analysis. Chapter 5 (Cost-Benefit Analysis) describes the cost-benefit analysis for the selected water and wastewater management alternatives including environmental impact analysis and financial analysis. In addition, it also includes sensitivity and risk analysis. Chapter 6 (Discussion and Conclusions) evaluates the assessment of BAT Finally, Chapter 7 (Recommendations) gives the recommendations for this study. 


\section{CHAPTER 2}

\section{LITERATURE REVIEW}

In this chapter, a brief literature review of the cost data for the different options used in the treatment of textile wastewater, are provided along with recent published studies. Alternative options taken into considerations are the ones that are used in this project.

\subsection{Investment and Operating Costs for Alternative Technologies}

The alternatives considered are activated sludge process, ozonation, membrane filtration process, membrane bioreactor process, and Fenton oxidation. These processes are evaluated in terms of their investment and operating costs with respect to the previous studies published in the literature.

\subsubsection{Activated Sludge Process Costs}

In textile sector, activated sludge process is one of the most preferential conventional methods for the treatment of wastewater generated [4]. The main reason for this preference is due to its low investment and operating costs compared to the other treatment methods such as physical and chemical treatments. Therefore, it can be concluded that biological treatment is the most economical wastewater treatment option in the textile industry [5]. 
In Turkey, there are many activated sludge implementations in textile mills in order to treat textile effluents. For instance, there exists a textile mill producing cotton fabrics in Uşak which has an activated sludge treatment plant with a flow rate of 200 $\mathrm{m}^{3}$ per day. In this plant, the daily treated amount of COD is approximately 300 kilograms. Investment cost and annual operating cost for this plant are reported to be 38,000 YTL and 20,000 YTL, respectively. Corresponding, unit investment cost for one meter cube of wastewater is 190 YTL, whereas operating cost is about 0.28 YTL [6]. In these cost figures, sludge disposal cost is neglected.

Another textile mill located in Kahramanmaraş has an activated sludge treatment plant with a flowrate of $1,100 \mathrm{~m}^{3} /$ day. Annual production capacity is 2,250 tones of cotton textile. Additionally, influent COD concentration of wastewater before entering the extended aeration is approximately 1,200 $\mathrm{mg} / \mathrm{L}$. For this system, investment cost comes about 177,500 YTL, and annual operating cost is nearly 195,700 YTL. Compared to the cost data for the wastewater treatment plant of the previously mentioned textile mill located in Uşak; unit investment cost for this plant is lower, namely 160 YTL. However, for this wastewater treatment plant operating cost per meter cubes of treated textile wastewater is $0.50 \mathrm{YTL}$, which is more than the previous one. Moreover, cost for the removal of one kilogram of COD becomes 150 YTL for this situation [6].

To the knowledge of the author of this thesis, there also exist two more textile mills established in Kahramanmaraş, having their own wastewater treatment plants consisting of an activated sludge systems which both have capacities of $2,000 \mathrm{~m}^{3}$ per day. Besides, they annually produce approximately 4,000 - 5,000 tones of cotton fabric. Similarly, investment and annual operating cost for these wastewater treatment plants are 360,000 YTL and 280,000 YTL, respectively. Consequently, for these wastewater treatment plants, the operating cost is $0.40 \mathrm{YTL}$ per $\mathrm{m}^{3}$ of wastewater treated [6]. 
Investment costs of the treatment plants for the textile industries mentioned above are composed of construction cost, equipment cost, and installation expenditure. As can be seen from the mentioned textile wastewater treatment examples, activated sludge systems in Turkey are installed with an investment cost in the range of 160 YTL to 200 YTL per meter cube of wastewater generated. This wide range is due to the difference in wastewater flowrate. This relative change in the investment cost with respect to the wastewater flowrate is illustrated in the graph given in Figure 2.1 [6].

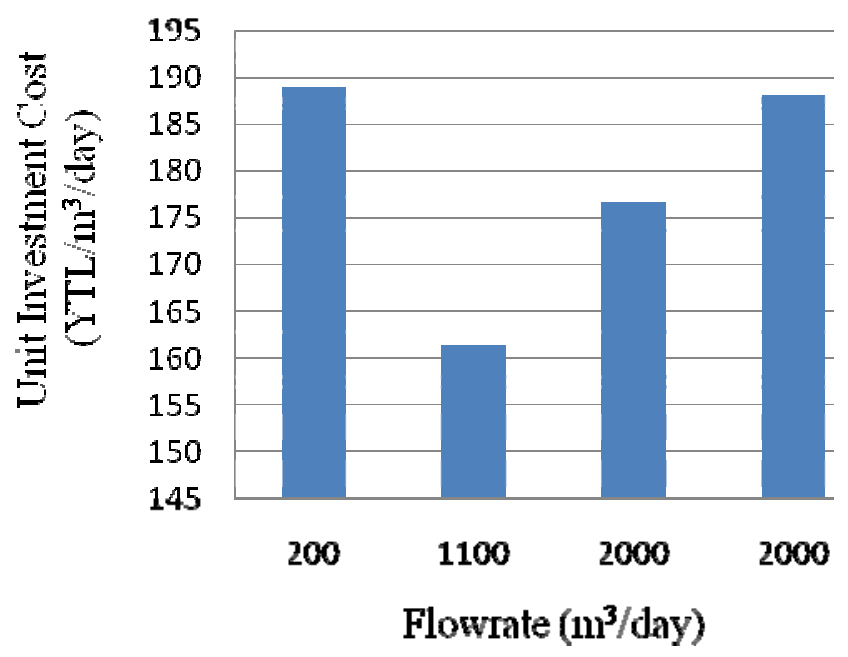

Figure 2.1. Unit investment cost versus wastewater flowrate for activated sludge systems existing in some of the textile mills located in Turkey

Unit investment cost per removed COD from the system is another important parameter. For the pre-mentioned examples of textile wastewater treatment plants in Turkey, this parameter is in the range of 125 YTL to 140 YTL. In Figure 2.2, change in unit investment cost according to COD removal is graphically presented [6]. 


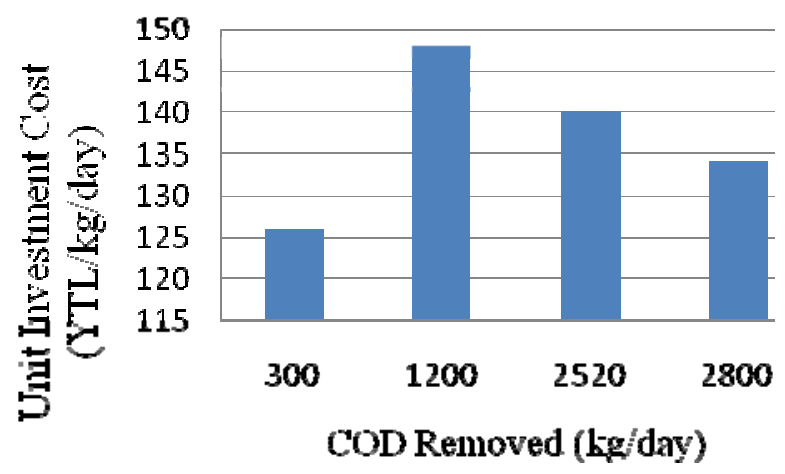

Figure 2.2. Relationship between unit investment cost and COD removed from activated sludge processes existing in some textile mills of Turkey

Energy, chemical, labour, fixed operating and maintenance costs are the major operating cost items taken into account. Operating cost per unit meter cube of treated wastewater for some textile mills located in Turkey is estimated at between 0.25 YTL and 0.50 YTL [6].

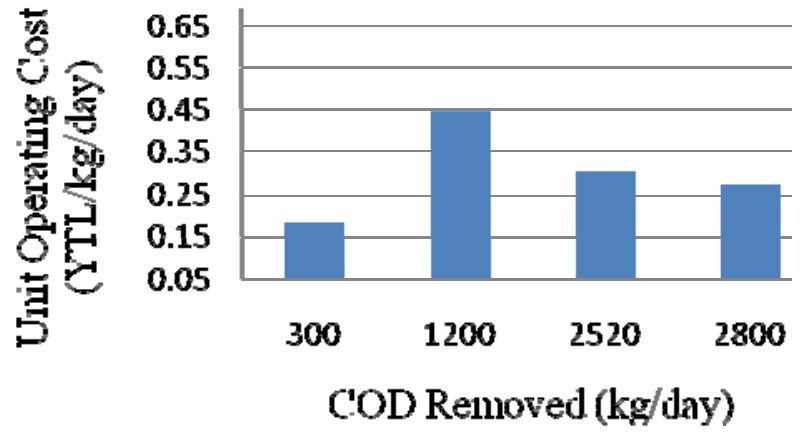

Figure 2.3. Relationship between unit operating cost and wastewater flowrate for activated sludge processes existing in some textile mills of Turkey 
Istanbul Technical University, Turkish Economy Bank and TML Construction Inc. performed a technical and an economical feasibility study of in-plant control for wool finishing textile industry in order to reduce water consumption and enhance water recovery on the basis of a survey conducted on a textile mill located in Istanbul [7]. In this survey, three different wastewater samples having different characteristics were analyzed by Erdoğan et al. [7]. First wastewater (Wastewater A) is the raw wastewater before in-plant control applications. Secondly, after applications of water minimization in-plant, generated wastewater was called as Wastewater B. Third and final one is Wastewater $\mathrm{C}$, the remaining wastewater obtained after water conservation and also application of recycling. Flowrate and characterization of these different types of wastewaters likely to be generated from the mill are summarized in Table $2.1[7]$.

Table 2.1. Flowrate and COD concentrations of wastewater A, B, and C from a textile mill in Turkey [7]

\begin{tabular}{cccc}
\hline \multirow{2}{*}{ Parameter } & \multicolumn{3}{c}{ Wastewaters } \\
\cline { 2 - 4 } & A & B & C \\
\hline \hline Flowrate $\left(\mathbf{m}^{\mathbf{3}} /\right.$ day $)$ & 444 & 294 & 194 \\
\hline COD $(\mathbf{m g} / \mathbf{L})$ & 687 & 1,038 & 1,460 \\
\hline \hline
\end{tabular}

In the same survey mentioned above, it was found out that each wastewater was biologically treated by conventional activated sludge process and discharged to a receiving environment. Erdoğan et al. [7] performed a feasibility analysis regarding the investment and operating costs of the treatment processes for three different wastewater types. Investment cost consisting of construction, electro-mechanic, and other costs for Wastewater A was approximately calculated as 127,602 USD. On the 
other hand, they reported investment costs for Wastewater B and Wastewater C as 115,242 USD and 111,331 USD, respectively. As can be seen, investment cost of treatment decreased by the decrease in flowrate.

Erdoğan et al. [7] also calculated the operating costs for each water management options in this survey according to manpower, chemical usage and energy usage. By means of both in-plant water minimization methods and water recovery and reuse techniques, effluent wastewater flowrates were decreased with an increase in effluent COD concentration. Therefore, unit investment costs showed an increase due to this increase in COD concentrations. When the flowrate of the system was $444 \mathrm{~m}^{3} /$ day, the monthly operating cost of the system was determined as 2,668 USD. However, this value was calculated as 2,680 USD for both Wastewater B and Wastewater C.

According to the examples given above, in textile wastewater treatment by the process of activated sludge process, investment cost and operating costs are strongly related with the wastewater flowrate of the plant and also with the COD removed during the treatment. Table 2.2 summarizes the investment cost and operating cost for an activated sludge system for different flowrate ranges for the textile industry in Turkey. Likewise, cost ranges for different COD concentrations are given in Table 2.3 . 
Table 2.2. Unit investment and operating costs for different flowrates [6]

\begin{tabular}{cccc}
\hline \hline & $\begin{array}{c}\text { Capacity } \\
\left(\mathbf{m}^{\mathbf{3}} / \mathbf{d a y}\right)\end{array}$ & $\begin{array}{c}\text { Unit Investment } \\
\text { Cost } \\
\left(\mathbf{Y T L} / \mathbf{m}^{\mathbf{3}} / \mathrm{day}\right)\end{array}$ & $\begin{array}{c}\text { Unit Operating } \\
\text { Cost } \\
\left(\mathbf{Y T L} / \mathbf{m}^{\mathbf{3}} / \mathbf{d a y}\right)\end{array}$ \\
\hline $\mathbf{1}$ & $<200$ & $190-690$ & $0.28-0.55$ \\
\hline $\mathbf{2}$ & $200-500$ & $190-470$ & $0.24-0.36$ \\
\hline $\mathbf{3}$ & $500-1100$ & $160-345$ & $0.24-0.50$ \\
\hline $\mathbf{4}$ & $1100-2000$ & $160-190$ & $0.40-0.50$ \\
\hline
\end{tabular}

Table 2.3. Unit investment and operating costs for different COD concentrations [6]

\begin{tabular}{cccc}
\hline \hline & $\begin{array}{c}\text { COD } \\
\text { Removed } \\
\text { (kg/day) }\end{array}$ & $\begin{array}{c}\text { Unit Investment } \\
\text { Cost } \\
\text { (YTL/kg/day) }\end{array}$ & $\begin{array}{c}\text { Unit Operating } \\
\text { Cost } \\
\text { (YTL/kg/day) }\end{array}$ \\
\hline $\mathbf{1}$ & $<300$ & $125-890$ & $0.18-0.61$ \\
\hline $\mathbf{2}$ & $300-1200$ & $125-150$ & $0.18-0.45$ \\
\hline $\mathbf{3}$ & $1200-2500$ & $140-150$ & $0.30-0.45$ \\
\hline $\mathbf{4}$ & $2500-3000$ & $135-140$ & $\sim 0.30$ \\
\hline
\end{tabular}

\subsubsection{Advanced Oxidation Processes}

In recent years, as a result of the changes and improvements in textile industry, textile wastewaters have become very difficult to be treated by physico-chemical and biological treatment methods due to not only its complex structure but also the 
diversity of dyes and chemicals used in the textile industry $[8,9,10]$. In most of the cases, these wastewaters are discharged without complete treatment and therefore they not only cause some negative effects on the environment but also cause esthetical problems.

Because of the abovementioned reasons, there exist advanced oxidation processes that can treat textile wastewaters from their toxic and refractory pollutants. These processes are mainly Fenton oxidation $\left(\mathrm{H}_{2} \mathrm{O}_{2} / \mathrm{Fe}^{+2}\right)$, Fenton-like oxidation $\left(\mathrm{H}_{2} \mathrm{O}_{2} / \mathrm{Fe}^{+3}\right)$, photo-Fenton processes $\left(\mathrm{UV} / \mathrm{H}_{2} \mathrm{O}_{2} / \mathrm{Fe}^{+2}\right)$, ozonation, combination of ozone with hydrogen peroxide, combination of ozone with UV, and hydrogen peroxide with UV combinations [11]. All these processes have both advantages and disadvantages. By means of advanced oxidation processes, in addition to COD and BOD removals, high level of color removal from textile wastewaters can be achieved, and this appears as an advantage of these processes over the conventional ones [9]. On the other hand, one of the disadvantages is that they have high investment costs [11].

In this part of the thesis, ozonation, Fenton oxidation and ozone with hydrogen peroxide combination are discussed in terms of investment costs and operation and maintenance costs according to the information reported in the literature.

\subsubsection{Ozonation Costs}

Ozone is a very powerful oxidant for both water and wastewater treatment [12]. After dissolving in water, ozone undergoes chemical reactions in two ways which are direct oxidation as molecular ozone, and indirect oxidation with the formation of secondary oxidants (e.g. hydroxyl radical). Ozone is not only used as a strong oxidant in the color and odor removal from wastewaters, but also as a strong disinfectant in water treatment [13]. 
Ozone is produced by ozone generators. In 1998, Brian et al. [14] performed a pilot scale study in Raleigh on technologies for removal of a highly colored industrial waste stream. Combination of ultraviolet light and hydrogen peroxide, carbon adsorption, ion exchange, and ozone were assessed for their efficiency in treating the colored wastewater with an approximate flowrate of 5,000 $\mathrm{m}^{3} /$ day. Equipment cost, namely ozone generator cost, was designated as 3,000 USD per meter cubes of ozone produced in a day. In addition, operating cost was calculated as 24 USD per each meter cubes of treated wastewater [14].

In another survey conducted in Uludag University in 2006, Solmaz et al. [15] examined three different treatment techniques which are coagulation, Fenton oxidation and ozonation for a pre-treated textile industry wastewater in order to compare their performances. Composite wastewater samples used in this survey were collected from the discharge point of an existing wastewater treatment plant, having $11,000 \mathrm{~m}^{3} /$ day of flowrate, of a textile factory in Bursa [15]. The wastewater treatment plant has physical (coarse screening, equalization, pumping station, rotary screening and neutralization) and biological treatment (activated sludge process) units, and the treatment performance is appropriate for existing discharge regulations. Initially, influent and effluent wastewater characterizations for the wastewater considered were evaluated. While the influent COD concentration to the wastewater treatment plant was measured as $668 \mathrm{mg} / \mathrm{L}$, the effluent COD concentration was $160 \mathrm{mg} / \mathrm{L}$ corresponding to a $76 \%$ removal.

In the abovementioned study, the experiments were conducted on the samples which were taken from the effluent of the existing wastewater treatment plant of the plant. Optimum ozone dosage was determined as $360 \mathrm{mg} / \mathrm{L}$ with $43 \%$ of COD removal and $97 \%$ of color removal [15]. 
Consequently, Solmaz et al. [15] assessed the operating costs of the alternatives taken under consideration. For instance, chemical cost was estimated to be 2.42 USD per each kilogram of ozone. Moreover, excluding labour and sludge disposal costs, the total operating cost was found as 4.94 USD per $\mathrm{m}^{3}$ of wastewater treated.

In a study performed by Boncz [16], wastewaters from several different types of economical activity amongst which the tanker cleaning industry were investigated by oxidation with ozone. The aim was to provide a strategy and the necessary data needed for the design of an oxidation process using combinations of ozone, $\mathrm{H}_{2} \mathrm{O}_{2}$, and UV irradiation. The research had been focused on the processes in which ozone is the primary oxidants. Boncz [16] stated that high cost of the oxidant is the major disadvantage of process. Each kilogram of ozone costed 3.5 EUR. In addition to this, it was expected that ozonation process implemented in the textile industry had an approximate operating cost with a range of $0.11-0.27$ EUR per each tonne. Each oxygen supply and energy accounted for around $37 \%$ of this cost; whereas depreciation and maintenance accounted for the remaining $25 \%$. Moreover, Boncz [16] also stated that ozonation process could cost up to 0.55 EUR per tonne for more heavily polluted industry effluents or landfill leachate.

Furthermore, in another study, Canizares et al. [12] described the technical and economic feasibilities of three different advanced oxidation processes which were conductive-diamond electrochemical oxidation, ozonation and Fenton oxidation. They compared these by assessing the three technologies with synthetic wastewaters polluted with different types of organic compounds and also with actual wastes generated from olive oil mills and from a fine-chemical manufacturing plant.

Canizares et al. [12] carried out ozonation experiments by continuously feeding an ozone/oxygen gas stream into a mixed semi-batch bubble reactor (continuous for gas and batch for liquid). The experimental setup consisted of an ozone generator of 
Model GMF-10, and a jacketed cylindrical reactor $\left(2.5 \mathrm{dm}^{3}\right)$ equipped with a porous gas distribution plate and baffles to increase the capacity for the absorption of ozone.

After the experimental study by Canizares et al [12], financial analyses of the processes were performed. The main items of equipment required in the case of ozonation are the reactor and the ozone generator. The prices of these items as a function of the ozone production required (sizing parameter) are shown in Figure 2.4. Canizares et al. [12] also stated that the figure also shows the best fit of the Williams equation indicated over Figure 2.4.

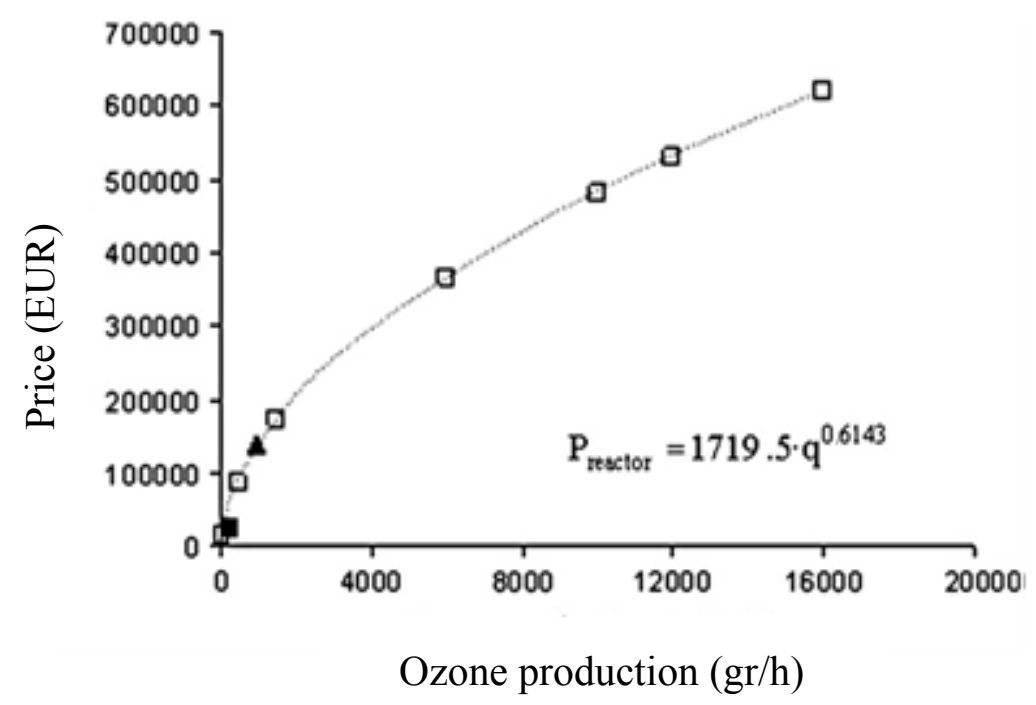

Figure 2.4. The price of the main equipment for ozonation treatment [12]

\subsubsection{Fenton Oxidation Costs}

In the textile industry wastewater treatment, one of the advanced oxidation technologies applicable is the Fenton oxidation process. Fenton's reagent which is a mixture of peroxide and ferrous sulfate is effective in decolorizing and reducing the 
COD content of the wastewater that contain reactive, direct, basic, and acid or disperse dye [17]. Some of the operational parameters that affect this process are $\mathrm{pH}$, ferric sulfate and hydrogen peroxide dosages [10].

For textile wastewaters, there are many applications of this process one of which was investigated by Solmaz et al. [15], where it is mentioned in the ozonation costs part of this chapter. Experiments were conducted with different $\mathrm{FeSO}_{4}$ and $\mathrm{H}_{2} \mathrm{O}_{2}$ dosages for the wastewaters generated in a textile mill located in Bursa in order to determine the best COD and color removal ratios. As a result of these experiments, removal ratios for COD and Color were evaluated as $78 \%$ and $95 \%$, respectively.

According to the abovementioned study, chemical costs for $\mathrm{FeSO}_{4} .7 \mathrm{H}_{2} \mathrm{O}$ and $\mathrm{H}_{2} \mathrm{O}_{2}$ were estimated at 0.35 USD per kilogram and 0.51 USD per kilogram, respectively. Moreover, operating cost for this Fenton oxidation process was determined approximately as 0.59 USD. However, this cost figure did not include labour and sludge disposal costs [15].

Another study available in the literature as regards, Fenton oxidation process was discussed in North Carolina in 1998 in the "Color Reduction and Removal" Seminar [18]. The aim of this seminar was to increase the importance of color issue among textile companies and increase the sharing of information concerning color reduction technologies. It was stated in this seminar that suitable color removal could be accomplished by more powerful oxidizing methods than the biological treatment systems. Fenton oxidation was discussed as one of these oxidizing methods. In the seminar operating cost range for Fenton oxidation process was stated as between $0.76 \mathrm{USD} / \mathrm{m}^{3}$ and $1.63 \mathrm{USD} / \mathrm{m}^{3}[18]$. 
Another environmental study using life cycle assessment (LCA) was carried out by Montano et al. [19]. To reach color removal by applying different type of photoFenton processes was the purpose of the study. In addition to this LCA, financial analysis was performed for each of the Fenton process alternatives. In Table 2.4, ferric sulfate and hydrogen peroxide costs can be seen according to the financial analysis done in this study.

Table 2.4. Ferric sulfate and hydrogen peroxide unit costs [19]

\begin{tabular}{lc}
\hline \hline \multicolumn{1}{c}{ Chemical } & $\begin{array}{c}\text { Cost } \\
\text { (EUR) }\end{array}$ \\
\hline \hline $\mathrm{FeSO}_{4}(\mathrm{~kg})$ & 0.25 \\
\hline $\mathrm{H}_{2} \mathrm{O}_{2} \% 50(\mathrm{~kg})$ & 0.22 \\
\hline \hline
\end{tabular}

In another study, Ustun et al. [20] worked on the treatment of the wastewater generated from the Bursa Organized Industrial Zone and tested three different processes which are Fenton oxidation, chemical coagulation, and ion exchange. Industrial zone considered consisted of 200 factories most of which are textile mills. Consequently, the wastewater characterization from the Zone had the same characteristics with a typical textile wastewater. The main aim of the study was COD and color removals from a wastewater flowrate of $48,000 \mathrm{~m}^{3} /$ day having a COD in the range of $113 \mathrm{mg} / \mathrm{L}$ to $149 \mathrm{mg} / \mathrm{L}$. In the study, chemical coagulation and ion exchange processes were applied after pre-treatment by Fenton oxidation process to the wastewater. It was assessed that the optimum concentrations for $\mathrm{FeSO}_{4}$ and $\mathrm{H}_{2} \mathrm{O}_{2}$ were determined as $20 \mathrm{mg} / \mathrm{L}$ and $70 \mathrm{mg} / \mathrm{L}$, respectively. As a result, unit operating cost for Fenton oxidation process was estimated to be 0.124 EUR per each $\mathrm{m}^{3}$ of wastewater treated. In addition to this, total operating cost that included all the 
treatment processes such as coagulation, ion exchange, and Fenton oxidation was determined as 2.54 EUR per $\mathrm{m}^{3}$ of wastewater where cost of sludge disposal was evaluated approximately 1.20 EUR per $\mathrm{m}^{3}$ [20].

Furthermore, Philippe et al. [10] stated in another study that in South Africa, there were many plants where Fenton processes were applied. They reported that in these textile plants color removal is achieved by Fenton process whereas COD removal is by activated sludge process. The average operating costs for these systems were stated as 0.4 USD per $\mathrm{m}^{3}$ which did not include the sludge disposal cost.

According to the abovementioned literature review for the Fenton oxidation process, chemical costs and operating costs for the application of this process can be summarized as in Table 2.5.

Table 2.5. Fenton oxidation process - Typical operating costs

\begin{tabular}{lcc}
\hline \hline & $\begin{array}{c}\text { Chemical Costs } \\
\text { (USD) }\end{array}$ & $\begin{array}{c}\text { Operating Costs } \\
\left(\mathbf{U S D} / \mathbf{m}^{\mathbf{3}}\right)\end{array}$ \\
\hline $\mathrm{FeSO}_{4}(\mathrm{~kg})$ & $0.35-0.38$ & $0.40-1.63$ \\
\cline { 1 - 2 } $\mathrm{H}_{2} \mathrm{O}_{2} \% 50(\mathrm{~kg})$ & $0.33-0.51$ & \\
\hline
\end{tabular}

\subsubsection{Peroxone Process Costs}

To obtain better treatment efficiency in the ozonation processes in order to increase the formation of $\mathrm{OH}$ radicals, $\mathrm{H}_{2} \mathrm{O}_{2}$ is added into the systems. In other words, the addition of both hydrogen peroxide and ozone to wastewater accelerates the decomposition of ozone and enhances production of the hydroxyl radical [21]. As it 
was stated previously, Solmaz et al. [15] studied ozonation process on the textile wastewater. They also investigated the performance of the peroxone process with respect to COD and color removal efficiencies. Different dosages of $\mathrm{H}_{2} \mathrm{O}_{2}(5,10$, and $25 \mathrm{mg} / \mathrm{L}$ ) were applied to the wastewater in 15 minutes of contact time. The optimum dosage was experimented on $5 \mathrm{mg} / \mathrm{L}$ with $54 \%$ of COD removal and $99 \%$ of color removal. For this system, they also evaluated the operating cost as 5.02 USD per each $\mathrm{m}^{3}$ of treated textile wastewater [15].

In a study conducted for a solid waste disposal site located in Tunis in Tunisia by Tizaoui et al. [22], the treatment of leachate was investigated. In the study, the influent COD was measured as $5,230 \mathrm{mg} / \mathrm{L}$. With the application of peroxone process, COD and color removal ratios were found as $48 \%$ and $94 \%$, respectively. An $\mathrm{H}_{2} \mathrm{O}_{2}$ dosage of $2,000 \mathrm{mg} / \mathrm{L}$ was experimented as the optimum dosage. In addition, the operating cost per each kilogram of treated COD was evaluated as 2.3 USD [22].

\subsubsection{Membrane Processes}

The interest in the advanced treatments aimed at textile wastewater reuse has grown sharply, especially to deal with problems of water shortages. Particularly, in some industrial applications where water consumption is high, this wastewater reuse aspect should be taken into account by the industrial sector. For that reason, various treatment processes were studied and applied to investigate the possibility of textile wastewater reuse. Within this research field, several experimental were performed and, according to these experiences, membrane processes are the most promising methods [23].

The main membrane filtration processes are microfiltration (MF), ultrafiltration (UF), nanofiltration (NF), and reverse osmosis (RO). These pressure-driven 
membrane processes use the pressure difference as a driving force to transport the solvent (usually water) through the membranes. Particles and dissolved components are partially retained on the membrane related to their properties such as size, shape, and charge [24].

Another application of membrane separation processes is for the separation of biomass after biological treatment. This is the membrane bioreactor process (MBR) which is the combination of a biological treatment (activated sludge process) and membrane filtration processes. This technology gets a favorable ranking throughout the industrial wastewater treatment technologies due to its performance in treated water quality or on wastewater reuse. In addition to the high effluent quality, these systems are much more compact systems than the conventional biological treatment systems applying sedimentation for solids separation after biological oxidation.

In the IPPC project, MF and NF processes were applied for dyeing wastewaters and also for the whole wastewater mixture generated from the various processes carried out in the selected textile mill. In addition, MBR system was investigated to treat the mixed wastewater of the mill. In this part of the thesis, a short literature review is presented regarding the investment and operating costs for membrane processes considered in the selected mill.

\subsubsection{Membrane Bioreactor (MBR) Costs}

The first reported application of MBR technology was in 1969, when an UF membrane was used to separate activated sludge from the final effluent of a biological wastewater treatment system and the sludge was recycled back into the aeration tank [25]. Today, MBR technology is widely applied not only for municipal wastewaters, but also for some industrial wastewaters. This technology emerged as an effective way of treating various forms of wastewater, as it is able to transform 
even very difficult to treat wastewaters into high-quality effluent that is suitable for reuse or for discharge into the environment.

There are many applications of MBR in textile industry one of which was performed by Zheng et al. [26] in 2006 in China. Lab-scale MBR system was conducted to treat the dyeing and printing wastewaters of a selected textile mill. Moreover, treatment efficiencies and costs were determined.

The system had a flowrate of $240 \mathrm{~m}^{3} /$ day. COD concentration was in the range of $128 \mathrm{mg} / \mathrm{L}-321 \mathrm{mg} / \mathrm{L}$. COD and color removal rates were experimented by Zheng et al. [26] as $80 \%$ and $60 \%$, respectively. In addition, two different membrane fluxes, $8 \mathrm{~L} / \mathrm{m}^{2} . \mathrm{hr}$ and $10 \mathrm{~L} / \mathrm{m}^{2} . \mathrm{hr}$ were applied to the system and financial analysis was performed according to these fluxes.

In the financial analysis, membrane costs and non-membrane cost including mechanical, electrical, civil investment costs were taken into account. On the other hand, membrane replacement cost, labour cost, chemical, and energy costs were assumed as the operating costs. In this analysis, non-membrane costs were approximately assumed as the $70 \%$ of the total investment costs. Table 2.6 shows the investment and operating costs for the MBR system reported by Zheng et al. [26]. 
Table 2.6. MBR System Costs [26]

\begin{tabular}{lcc}
\hline & \multicolumn{2}{c}{ Membrane Flux $\left(\mathbf{L} / \mathbf{m}^{2} \cdot \mathbf{h r}\right)$} \\
\cline { 2 - 3 } & $\mathbf{8}$ & $\mathbf{1 0}$ \\
\hline \hline Membrane Costs (USD) & 18,150 & 14,500 \\
\hline Non-membrane Costs (USD) & 33,850 & 33,850 \\
\hline Total Investment Costs (USD) & 52,000 & 48,350 \\
\hline Operating Costs (USD/m $\left.{ }^{\mathbf{3}}\right)$ & 0.20 & 0.18 \\
\hline \hline
\end{tabular}

In another survey, Churchouse and Wildgoose [27] stated that membrane costs were decreased to 60 USD per each $\mathrm{m}^{2}$ of membrane from 400 USD per each $\mathrm{m}^{2}$ between the years 1992 and 2004 due to three reasons. The first reason was stated as the increase in the flux value in the design. Secondly, membrane life expectancy increased from 2 years to nearly 8 years. The final reason was increasing competition among membrane producing companies.

Moreover, according to this study performed by Churchouse and Wildgoose [27], Figure 2.5 shows the operating cost change between the years 1992 and 2004 of a MBR plant with a capacity of $2,000 \mathrm{~m}^{3} /$ day. 


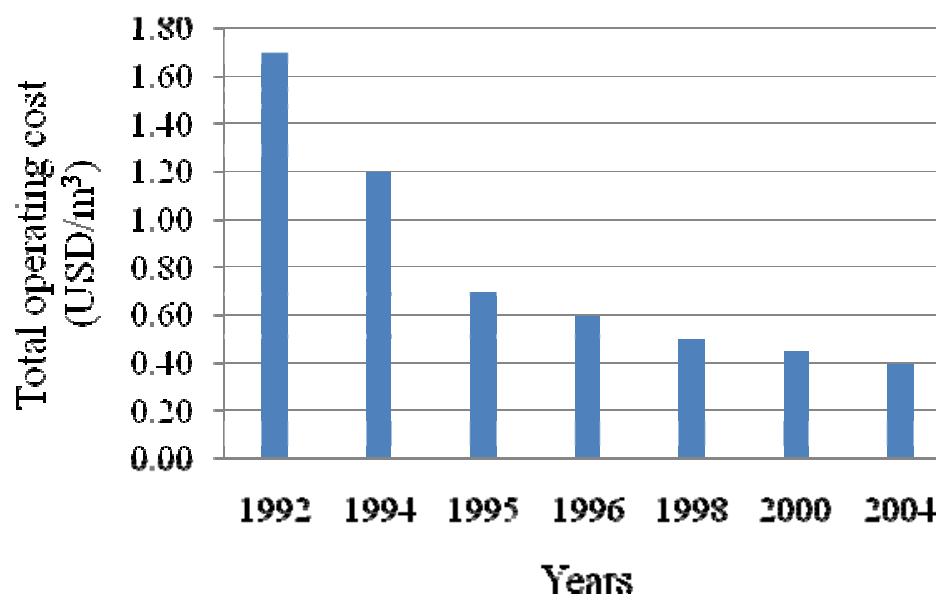

Figure 2.5. MBR operating cost change [27]

\subsubsection{Membrane Filtration Costs}

Membrane filtration processes are mainly used in the industrial wastewaters in order to achieve wastewater treatment and reuse. The main industries that use membrane filtration processes are pulp and paper industry, food industry, metal industry, and textile industry.

For instance, in Egypt, Hafez et al. [28] performed a techno-economic study on food industry by applying membrane separation technologies. They applied NF and RO for a plant with $1,200 \mathrm{~m}^{3} /$ day capacity. For this system, total investment cost was evaluated as 254,000 USD whereas operating cost was 0.23 USD per $\mathrm{m}^{3}$ of wastewater treated.

In 2005, European Union Association (EWA) [29] performed wastewater treatability and wastewater reuse studies on textile wastewaters. NF and UF membranes were used and evaluated in these studies. In terms of NF application for such systems, 
treatment cost was determined in the range of 0.57 EUR per $\mathrm{m}^{3}$ and 0.63 EUR per $\mathrm{m}^{3}$. However, this range was increased to the range between 0.67 EUR per $\mathrm{m}^{3}$ and 1.04 EUR per $\mathrm{m}^{3}$ in the case of UF application before NF [29].

Another NF process applied for textile wastewaters was conducted by Florio et al. [30]. In this pilot-scale study, lifetime of mechanical equipment was assumed as 10 years whereas membrane lifetime was assumed as 3 years. For this system, operating cost was evaluated as 0.60 EUR per $\mathrm{m}^{3}$ of wastewater.

MF was applied before NF in the study performed by Marcucci et al. [31]. The study was applied on the biologically treated textile wastewater in order to reuse wastewater in the production process. In the study, sand filtration, MF, and NF were applied respectively to the wastewater with a flowrate of $1,500 \mathrm{~m}^{3} /$ day. Depreciation period was assumed as 3 years. As a result, unit operating cost for the application of these three processes was estimated at 0.34 EUR per $\mathrm{m} 3$ of wastewater treated.

In a recent study by Guiziou et al. [32], the industrial use of soda cleaning-in-place solution coupled with membrane regeneration was investigated and it has been indicated that running and investment costs for MF, UF, and NF, systems are as indicated in Table 2.7. As their target was to clean caustic solution to the critical suspended solids concentration of less than $3 \mathrm{~g} / \mathrm{L}$, they reported that NF seems to be the more appropriate operation. 
Table 2.7. Investment and running costs for MF, UF, and NF [32]

\begin{tabular}{ccc}
\hline \hline & $\begin{array}{c}\text { Investment Costs } \\
(\text { EUR })\end{array}$ & $\begin{array}{c}\text { Running Costs } \\
(\text { EUR/year })\end{array}$ \\
\hline \hline MF & 71,530 & 9,856 \\
\hline UF & 76,790 & 11,878 \\
\hline NF & 108,380 & 15,754 \\
\hline \hline
\end{tabular}

In another survey, Gorenflo et al. [33] carried out NF application for conventionally pretreated groundwater with elevated hardness and content of natural organic matter in a German water treatment plant of the public works of Mainz. NF200B type of NF membrane was used in the experiments. Cost calculations were also performed in the scope of the study. For a wastewater capacity of $20,000 \mathrm{~m}^{3} /$ day, the operating cost of the NF plant was estimated at about 0.23 EUR per $\mathrm{m} 3$ of wastewater treated.

Bruggen et al. [34] performed a study on the application of NF for the removal of pesticides, nitrate, and hardness form groundwater. In the first part of this study, the removal of four pesticides, the removal of hardness and the removal of nitrates with the membranes NF70, NF45, UTC-20 and UTC-60 were experimentally studied. Then, in the second part, economic evaluations of the selected membranes were indicated. Bruggen et al. [34] used the equations mentioned in Table 2.8 in order to estimate the investment costs. 
Table 2.8. Investment cost formulas for membrane filtration processes [34]

\begin{tabular}{lll}
\hline \hline \multicolumn{1}{c}{ Cost component } & \multicolumn{2}{c}{ Formula } \\
\hline \hline Civil investments & $C_{\text {otwt }}=862 \times Q+1,239 \times n$ & $(1)$ \\
\hline Mechanical investments & $C_{\text {meoh }}=3,608 \times Q+908 \times n$ & $(2)$ \\
\hline Membrane investments & $C_{\text {membrane }}=780 \times n$ & $(3)$ \\
\hline Additional investments & $2 \%$ ef the total trvestment cost \\
\hline \hline Q: flowrate $\left(\mathrm{m}^{3} / \mathrm{h}\right) \mathrm{n}:$ number of modules
\end{tabular}

In addition to the abovementioned investment cost equations, Bruggen et al. [34] assumed some of the operating cost components which were maintenance costs, quality control costs, and operation of the installation as $2 \%$ of the total investment costs. In addition to this, chemical costs were stated in the range between 0.020 EUR to 0.025 EUR per $\mathrm{m}^{3}$ of filtrate. 


\section{CHAPTER 3}

\section{LEGISLATION BACKGROUND}

\subsection{Integrated Pollution Prevention and Control Directive}

In the last decades, environmental problems increased substantially with the intensification of urbanization and industrialization throughout the world. Therefore, in order to protect the environment extensively and effectively, there arose a need for a strategy targeting to an integrated prevention and control of pollution such as air emissions, wastewater discharges, and solid wastes caused by industrial activities. Within this respect, pollution prevention and control became one of the cornerstones of the sustainable development [35]. For that reason, in the EU Member States, the pollution generated from the industrial facilities is under management with an integrated pollution management approach.

In the European Community's Fifth Environmental Action Programme, adopted in 1993, it was stated that priority should be given to the integrated pollution control, which would not only advance the resources and regenerative capacity of the nature but also improve a more sustainable balance between human activity and socioeconomic development. As a result of this purpose, the IPPC Directive (96/61/EC) was published in 1996, and has been implemented in all of the Member States since October 2007 [1]. The reason why the Directive is implemented 10 years later than the publication is to ensure that all other existing installations in the Member States fully comply with the Directive in this transition period. 
The IPPC Directive is based on four main principles, which are namely:

- An integrated approach,

- Best available techniques,

- Flexibility,

- Public participation.

The integrated approach means that the whole environmental performance of the plant must be taken into account, covering such as emissions to air, water and land, generation of waste, use of raw materials, energy efficiency, noise, prevention of accidents, and restoration of the site upon closure [36].

At this point, the main objective of the IPPC Directive is "to prevent emissions into air, water or soil wherever this is practicable, taking into account waste management, and, where it is not, to minimize them in order to achieve a high level of protection for the environment as a whole concerning an integrated approach" [1]. In order to achieve this purpose, according to the Directive, Member States should take some necessary precautions for the installations. These precautions are mainly;

- Application of best available techniques for prevention of pollution;

- Causing no significant pollution;

- No waste production in accordance with Council Directive 75/442/EEC of 15 July 1975 on waste; where waste is produced, it is recovered or, where that is technically and economically impossible, it is disposed of while avoiding or reducing any impact on the environment;

- Efficient usage of energy;

- Prevention of accidents and limiting their consequences; and

- Definitive cessation of activities. 
If the installations comply with the abovementioned precautions, a permit is given to the Member States by the competent authorities. Moreover, the IPPC permit is classified into two by the Directive as permits for new installations and permits for the existing ones. Both types of permits should include details of the integrated environmental protection arrangements as stated in the Directive [1].

One of the most important requirements that the Directive indicates is the use of "best available techniques" (BAT) for the integrated prevention and control of environmental pollution. In the Directive, the BAT is defined as "the most effective and advanced stage in the development of activities and their methods of operation which indicate the practical suitability of particular techniques for providing in principle the basis for emission limit values designed to prevent and, where that is not practicable, generally to reduce emissions and the impact on the environment as a whole". The Directive also presents the explanation of "available techniques" as the technically and economically implementable techniques for the relevant industrial sector taking into account the costs and advantages [1].

The IPPC Directive also contains elements of flexibility by allowing the licensing authorities, in determining permit conditions, to take into account:

- the technical characteristics of the installation,

- its geographical location and,

- the local environmental conditions [36].

Furthermore, public participation is another important part of the Directive. Before the competent authorities make their final decision for submission of permits, the public should be informed on the new installation or the existing one, and the measures taken in these installations. Therefore the public can comment on those issues [1]. 
There are six main categories of industrial activities which are power plants, production and processing of metals, mineral industry, chemical industry, waste management and other activities mentioned in Section 6.2 of Annex 1 of the IPPC Directive. For each of these activities, the IPPC Directive has Reference Documents called as Best available Reference Documents (BREF) developed by technical working groups providing supplementary information about the best available techniques to be used in the relevant industrial activities.

According to the Directive and the Reference Documents, BAT corresponds to the technologies, techniques, or organizational measures when implemented to an industrial installation, procures with minimum environmental impact and acceptable costs $[1,37]$. In other words, before the decision of BAT, not only environmental utilities, but also its economic benefits have to be taken into account. Therefore, there exists a need for technical feasibility, environmental benefit, and economic feasibility analyses in order to assess the BAT for each industrial sector.

The aforementioned BREFs act as valuable tools for providing relevant information concerning best available techniques collected from a number of different sources. These documents are intended to be used for the determination of BAT from the technically implementable point of view. Moreover, since the best available techniques change over time due to change in technology, these Reference Documents are also reviewed and updated as appropriate [38].

As mentioned in the Article 9 (1) of the Directive, "the emission limit values and the equivalent parameters and technical measures referred to in paragraph 3 shall be based on the best available techniques, without prescribing the use of any technique or specific technology, but taking into account the technical characteristics of the installation concerned, its geographical location and the local environmental conditions". Briefly, the aim of BAT under the IPPC Directive is to take into account 
the likely costs and benefits of measures as well as protecting the environment as a whole to avoid creating a new or more serious problems when solving another. For this purpose, in addition to the technical BREFs, there is another Reference Document called as "Reference Document on Economics and Cross-Media Effects" published in $2006[1,2]$.

Textile industry is one of the industries included in the activities mentioned in Section 6.2 of Annex 1 of the IPPC Directive under "other activities" category. It is indicated in the Directive that "plants for pre-treatment (operations such as washing, bleaching, and mercerization) or dyeing of fibres or textiles where the treatment capacity exceeds 10 tones per day" have to take permit according to the IPPC Directive, and they have to implement best available techniques mentioned in the Reference Documents in order to achieve a sound integrated pollution prevention and control.

\subsubsection{Reference Document on Economics and Cross-Media Effects}

\subsubsection{General Information}

The scope of this Reference Document is to provide assistance to both technical working groups preparing BREFs and industries need permits when considering environmental and economic contradictions that can occur during the determination of the techniques to be implemented under the frame of IPPC Directive. For the decision of BAT, it needs to balance environmental impacts against the costs by setting out a clear and transparent framework described in the methodologies given in this document. On the other hand, "where there is an obvious conclusion or where there is broad agreement as to which alternative is the preferred option for implementation, then there will be no need to apply the methodologies set out in this Reference Document" [2]. 
In this document, four core principles are discussed in different chapters;

- Cross-media effects - Methodology for the determination of techniques to be implemented under IPPC Directive offering the highest level of protection for environment as a whole.

- Costing methodology - Methodology needs to be done for the determination of costs of techniques to be considered as BAT, since the Directive requires technically and economically implementable techniques.

- Evaluating the alternatives - Methodology to balance the economic costs against the environmental benefits.

- Evaluating the economic viability - Assessment of the economic viability of the industrial sector implementing the selected techniques [2].

Consequently, this Reference Document discusses all the requirements stated in the scope of the IPPC Directive. Within the framework of the implementation of the IPPC Directive, the characterization of the techniques and the possible abatement options are able to be done with regard to environmental benefits, technical practicability and especially economic feasibility under the guidance of this Reference Document.

\subsubsection{Cross-Media Guidelines}

The alternative techniques determined under the IPPC Directive should be taken into consideration in terms of their environmental effects that need to be prevented, or where this is impossible should be minimized in order to protect the environment as a whole. Therefore, before the decision of the BAT, the determination of the least 
environmentally damaging options should be analyzed according to some guidelines. For this purpose, cross-media guidelines are represented in the Reference Document on "Economics and Cross-Media Effects". In other words, this document gives a methodology for the choosing the best option for the environment. Furthermore, the methodology described in this document is a truncated version of Life Cycle Analysis, which has been adapted so that the assessment is restricted to the frame of IPPC [2].

Mainly, four guidelines are discussed in order for the determination of the crossmedia effects of the alternative options selected for the relevant industrial installation. These four steps of the methodology are:

- Scoping and identification of the alternative options;

- Inventory of emissions;

- Calculation of the cross-media effects;

- Interpretation of the cross-media conflicts.

The methodology for the cross-media effects is summarized in Figure 3.1. It is also stated that at any of the cross-media determination step, if there is sufficient justification to come to a conclusion, the justification of the decision should be stopped and set out [2]. 


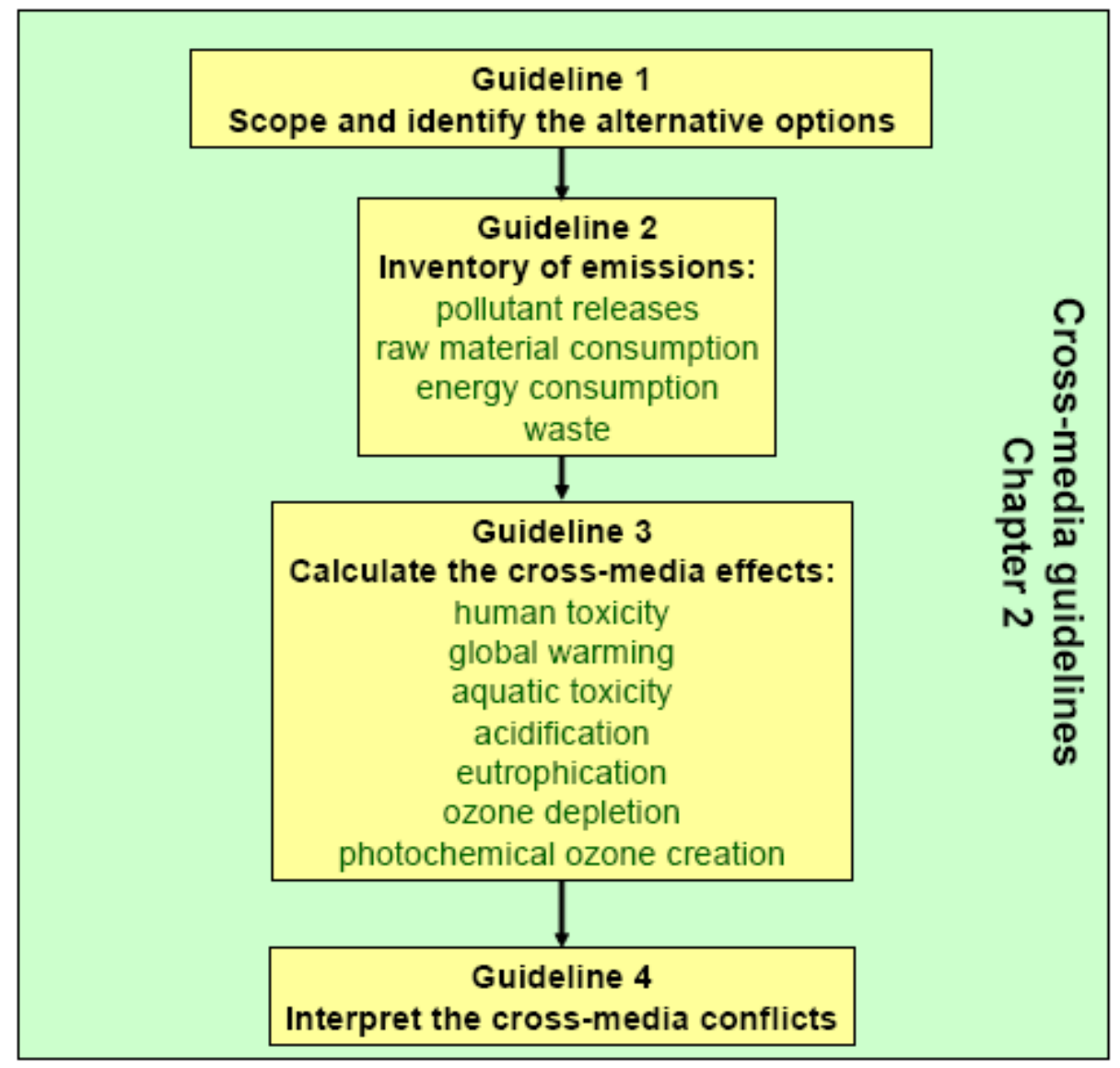

Figure 3.1. Chart for cross-media guidelines [2]

The first stage of the cross-media methodology is the identification of the alternatives to be considered as best available techniques according to the requirements stated in the IPPC Directive. The most important point in this stage is that the alternative options should sufficiently be described in order to prevent any ambiguity that can occur. Moreover, the size and capacity of the alternative proposal should be fixed in order to compare these options under the same basis [2]. 
According to the methodology stated in the Reference Document on "Economics and Cross-Media Effects", the next stage is the presentation of the inventory of consumptions and emissions. In other words, significant environmental releases and the resources of each alternative option selected to be the best available technique should be listed and quantified. This list should include the pollutants released from the selected alternative options, raw materials that are consumed during the processes including water consumption. In addition, energy used and wastes generated from the mentioned alternatives should be stated in this stage.

The third stage of the methodology is the calculation of the cross-media effects. It is stated that in order to assess the environmental effects for each alternative technique under consideration, different pollutants generated from the selected alternatives should be compared with respect to seven environmental themes. The themes are:

- Human toxicity,

- Global warming,

- Aquatic toxicity,

- Acidification,

- Eutrophication,

- Ozone depletion,

- Photochemical ozone creation potential.

Based on each abovementioned theme, the effects of alternative options need to be taken into account. Moreover, there may be effects in one medium such as only air or water, or more than one medium such as water and air together. During the assessment, in order to compare the effects, an equivalent reference substance representing the pollution level should be chosen [2]. 
The final stage is the interpretation of the cross-media conflicts. According to the results of the evaluations outlined in the cross-media methodology, comparisons of the alternative options should be done as transparent as possible. Consequently, this Reference Document gives a comprehensive methodology. However, it is not so much exclusive for some of the individual cases concerned under IPPC Directive. Since the Directive requires the consideration of some environmental issues, such as noise, odour, vibration, and etc., there may be some additional factors that should be taken into account in the assessment [2].

\subsubsection{Costing Methodology}

The IPPC Directive indicates that while determining the best available technique, not only the option that has the lowest impact on the environment as a whole is decided as BAT, but also the most economic option should be selected. As a result of this, there exists a need for comparison of the costs of the alternative options in addition to the cross-media assessment. The Reference Document on "Economics and CrossMedia Effects" sets a framework for costing methodology.

As in the cross-media methodology, the first step to be done is scoping and identifying the alternative options considered under the IPPC Directive. After the identification stage, the cost data for each option need to be gathered and then validated. In order to make the assessment as transparent as possible, the cost components should be defined like investment costs, operating and maintenance costs, revenues, benefits and avoided costs. In addition to these cost components, for each alternative option considered, interest rates, discount rates, the economic lifetime of the equipment and any scrap value that equipment might have should be presented and processed. Consequently, the calculated costs by means of guidelines stated above should be attributed to environmental protection. The abovementioned steps of the costing methodology are given as a flow chart in Figure 3.2 below [2]. 


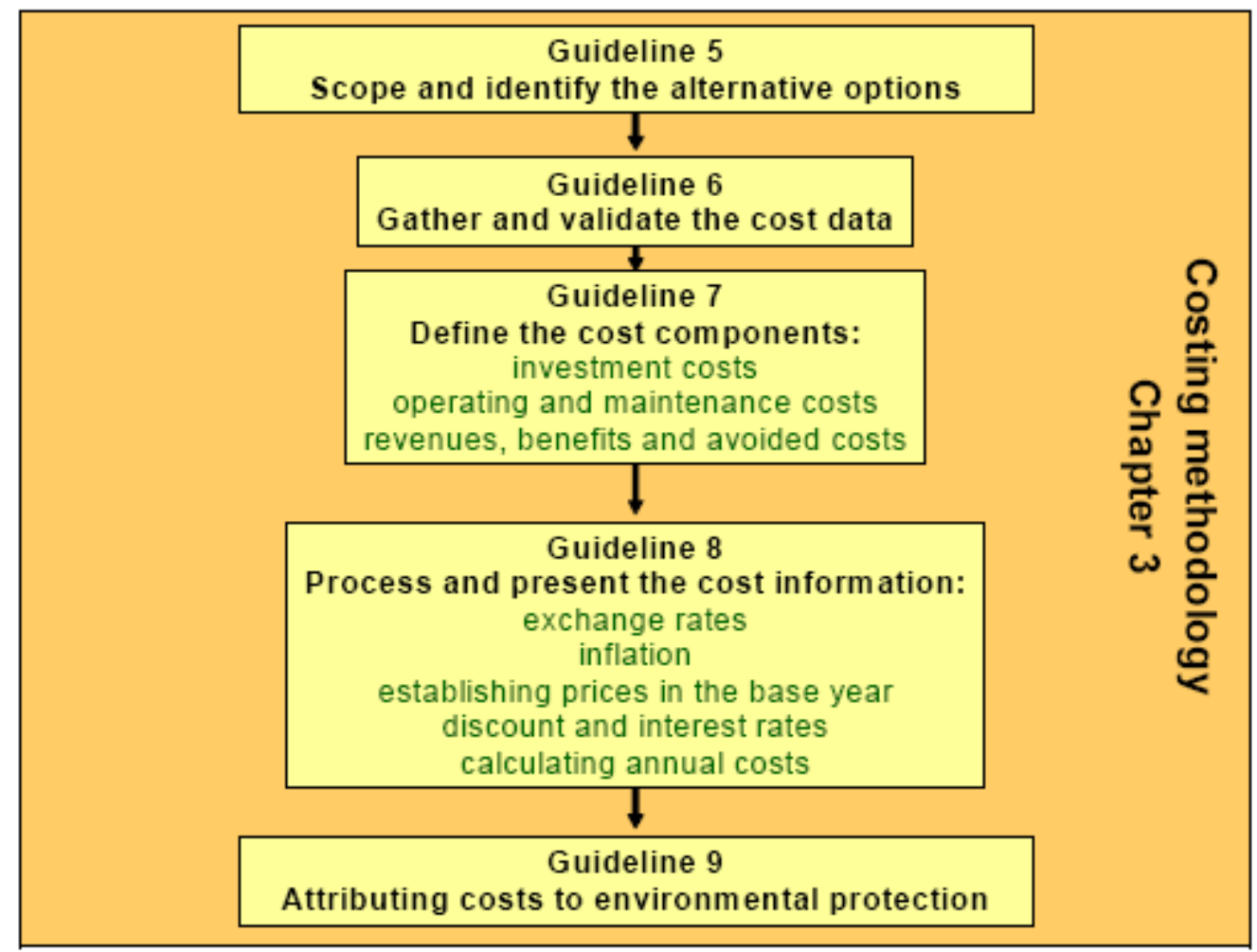

Figure 3.2. Chart for costing methodology [2]

It is seen from Figure 3.1 and Figure 3.2 that first steps of both the cross-media methodology and the costing methodology are the same. However, more information such as the technical specifications of the alternative options should be included in the Guideline 5 in addition to Guideline 1. For instance, these technical specifications can established as the expected technical and economic lifetime of the equipment, operational data such as energy use, maintenance, water consumption, and use of reagents. In this step, the performances or the efficiencies of the alternative options considered should be indicated [2]. 
The aim of the second stage of the costing methodology is to gather the cost data from different sources. These sources can be industries, technology suppliers, authorities, consultants, research groups, published information, and etc. The data should be stated clearly with introducing the source and year that is gathered from. In the Reference Document, it is also stated that in order to describe the validity of the data, quantitative ranges should be provided. If it is not possible, qualitative indication can be used instead of quantitative ranges. Moreover, it is preferable to use recent cost data.

Defining the cost components is another important stage in the methodology. Each potential BAT that can be applied at a typical industrial installation is connected in the economic assessment with a set of indicators reflecting the expected economic costs and benefits from its introduction [39]. The Reference Document sets these indicators as investment costs, operating and maintenance costs, benefits and revenues, etc. Investment costs are mainly all the expenses due to civil, electrical, and mechanical works of the BAT. In other words, expenditures for the purchase and assembly of necessary BAT equipment are the main investment cost components. Operating and maintenance costs, on the other hand, include the costs of annual quantities of fuels, electricity, raw and auxiliary materials. In addition, costs of consumables such as replacement parts necessary for BAT maintenance, management and disposal of wastes caused by BAT, salaries of the personnel responsible for the proper operation and maintenance of BAT are under the frame of operating and maintenance cost aspects $[2,39]$. The Reference Document states that revenues, avoided costs and benefits should also be discussed separately from investment expenditures or operating and maintenance costs in the costing methodology for each potential BAT considered. Revenues may be the sales of generated energy, heat, and treated effluent for irrigation, produced by-products by applying the BAT, and are the residual value of equipment. On the other hand, avoided costs are related to the recovery and reuse of materials as a result of potential 
BAT application [39]. Furthermore, savings on energy, labour, maintenance, capital due to more effective use of plant, and disposal costs are adopted as avoided costs [2].

According to the Reference Document, in the costing methodology, some cost components such as taxes, and subsidies should be identified separately. Besides, indirect costs, for instance, changes in demand in the market, knock-on effects, and external costs should be set separately in the analysis [2].

In order to calculate the costs of the alternative options considered as BAT for an installation, the Reference Document serves a method, namely "scale exponent method". This method is used for calculating the costs of a plant to a different scale to the original quotation. If costs of one size of a plant are known, by using this method, the costs of another plant can be estimated. The formula and the definitions of the components are given in Table 3.1 below. The below mentioned rough approximation factor, e, changes with respect to the plant or equipment capacity. On average, this value can be taken as 0.6 . For larger plants, it is appropriate to accept this value between 0.8 and 1.0 . 
Table 3.1. The Scale Exponent Method [2]

\begin{tabular}{ccc}
\hline \hline Formula & & $\mathrm{C}_{y}=\mathrm{C}_{x}\left[\frac{y_{x}^{*}}{x}\right]^{*}$ \\
\hline \hline Definitions & $\mathrm{C}_{\mathrm{y}}$ & cost of plant y \\
& $\mathrm{C}_{\mathrm{x}}$ & cost of plant x \\
& $\mathrm{y}$ & scale of plant y (size or throughput) \\
& $\mathrm{x}$ & scale of plant x (size or throughput) \\
& $\mathrm{e}$ & rough approximation factor \\
\hline \hline
\end{tabular}

After gathering the cost components and validating them, the cost information should be processed and presented. The original cost data should be expressed in the price level of a common year. Discount rate is the rate at which future values are discounted to present [40]. In other words, it can be considered as the opportunity cost of capital [41]. During the costing of the alternatives, discount and interest rates should be clearly stated with referencing and underlying all the assumptions made. Moreover, the cost data should be calculated and presented as annual basis. However, the costs for the industrial pollution control systems can be assessed by calculating the cost per unit of product and the cost per unit pollutant reduced or avoided. As a result, the affordability of the alternatives used can be compared with the prices of the goods produced, and the cost-effectiveness of the techniques used can easily be analyzed [2].

The last step of the costing methodology is the attributing the costs to environmental protection. It should be clearly stated that the purpose of the alternative options to be implemented is either for the reduction or prevention of the environmental pollution or for other reasons such as investment expenditure in energy conservation or waste minimization. Therefore, the differentiation should be done between those costs that 
are offset by mentioned commercial benefits and those that can be attributed to environmental protection [2].

\subsubsection{Evaluation of the Alternatives}

In accordance with the Reference Document on "Economics and Cross-media Effects", after the estimation of both the environmental effects and economic costs for alternative techniques each of which is a potential for BAT, the comparison of these alternatives should be done to determine which meet the BAT criteria. Therefore, cost effectiveness of each alternative, apportionment of costs between alternative, and balance between costs and environmental benefits should be assessed [2]. The methodologies discussed previously are put together with the methodologies about the evaluation of the alternative, and given in Figure 3.3.

Cost effectiveness analysis is a type of cost-benefit analysis which is more simplified one as environmental benefits are quantified rather than valued. Cost effectiveness of an alternative technique is defined typically as annual cost of the technique per annual reduction of emissions due to application of that [2]. In the cost-benefit analysis, on the other hand, the objective is to identify and monetize all the possible impacts of the alternatives in order to determine the costs and benefits [41].

In addition to cost effectiveness analysis, while evaluating the alternatives, the determined costs should be apportioned between pollutants. By implementing an alternative, there may be a range of pollutants that will be reduced. Therefore, apportioning of the costs between these pollutants will be essential. In order to do this, IPPC Directive prefers a method of apportionment that the costs of the alternative technique can be attributed in full to the pollution problem for which the measure was originally intended [2]. 


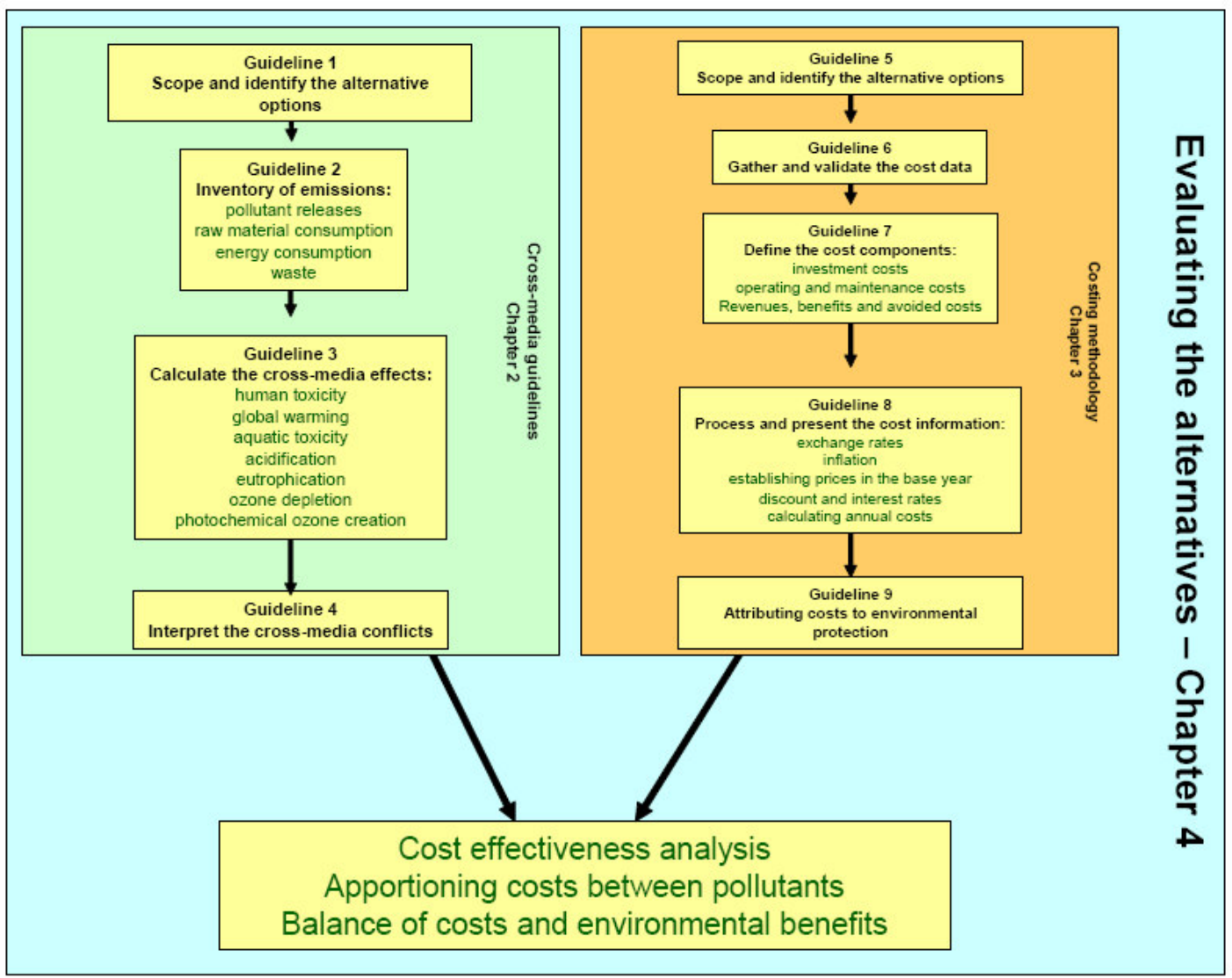

Figure 3.3. Chart for evaluating the alternatives [2]

The third step in the evaluation of the alternatives is the balancing costs and environmental benefits. The Reference Document sets methodologies on how to assess cost effectiveness. In some of the Member States, i.e. Denmark, United Kingdom, Sweden, Belgium, and etc., reference prices are used for the decision of the BAT. Reference prices are useful for determining whether the alternative option invested represents value of money, or not. If this value is known with attributing to an environmental effect, then it can be used in accordance with the processes mentioned in Figure 3.4 below. 
Furthermore, assessment of the cost effectiveness can also be done by comparing the costs of the alternatives against the social cost of environmental impact that is avoided by implementing those alternatives.

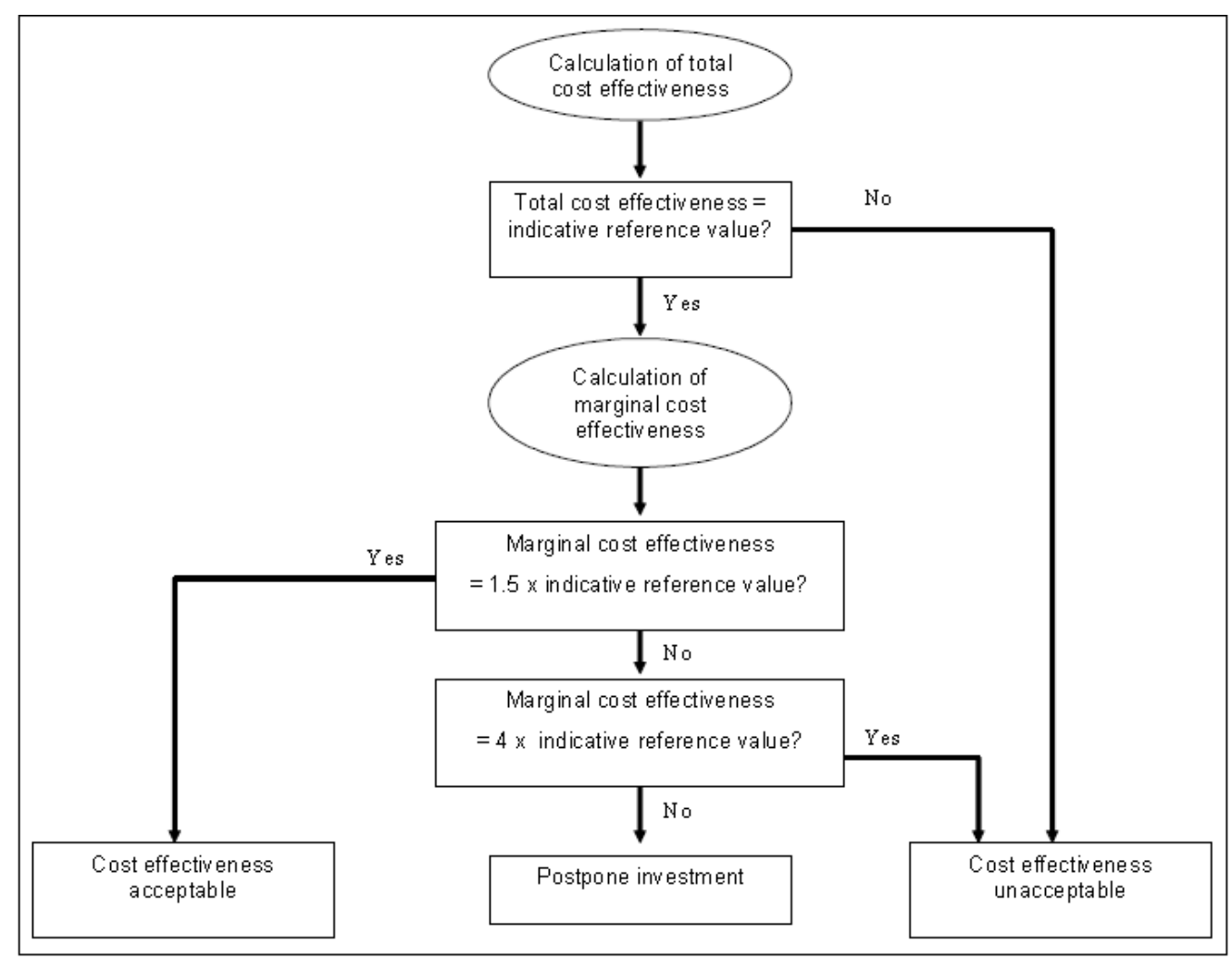

Figure 3.4. Decision making process for evaluating cost effectiveness [2]

In the first methodology, namely cross-media methodology, the alternatives are assessed according to their environmental impacts, and all the environmental issues are set. Secondly, costs of each alternative under consideration are estimated by means of the guidelines given in the costing methodology. The last evaluation is done by integrating these two guidelines, so that balance has been introduced 
between the environmental benefits and the costs of the alternatives. In addition to this, once the cost effectiveness of each alternative technique is determined and ranked, it allows to make an objective justification for setting the best available alternative.

\subsubsection{Economic Viability in the Sector}

As it is stated, the IPPC Directive concerns not only the technically applicable alternative as BAT, but also the selected option should be economically viable for the relevant industrial sector. Therefore, after having done cross-media analysis and financial analysis for the alternative options that are potential of BAT, economic viability in the sector should be assessed. For this purpose, a framework is provided in the Reference Document mentioned as "Economic and Cross-Media Effects".

According the Reference Document, the evaluation of the economical viability is schematically assisted in Figure 3.5. Most important issues to be considered while assessing the economic viability are:

- Industry structure,

- Market structure,

- Resilience,

- Speed of implementation [2]. 


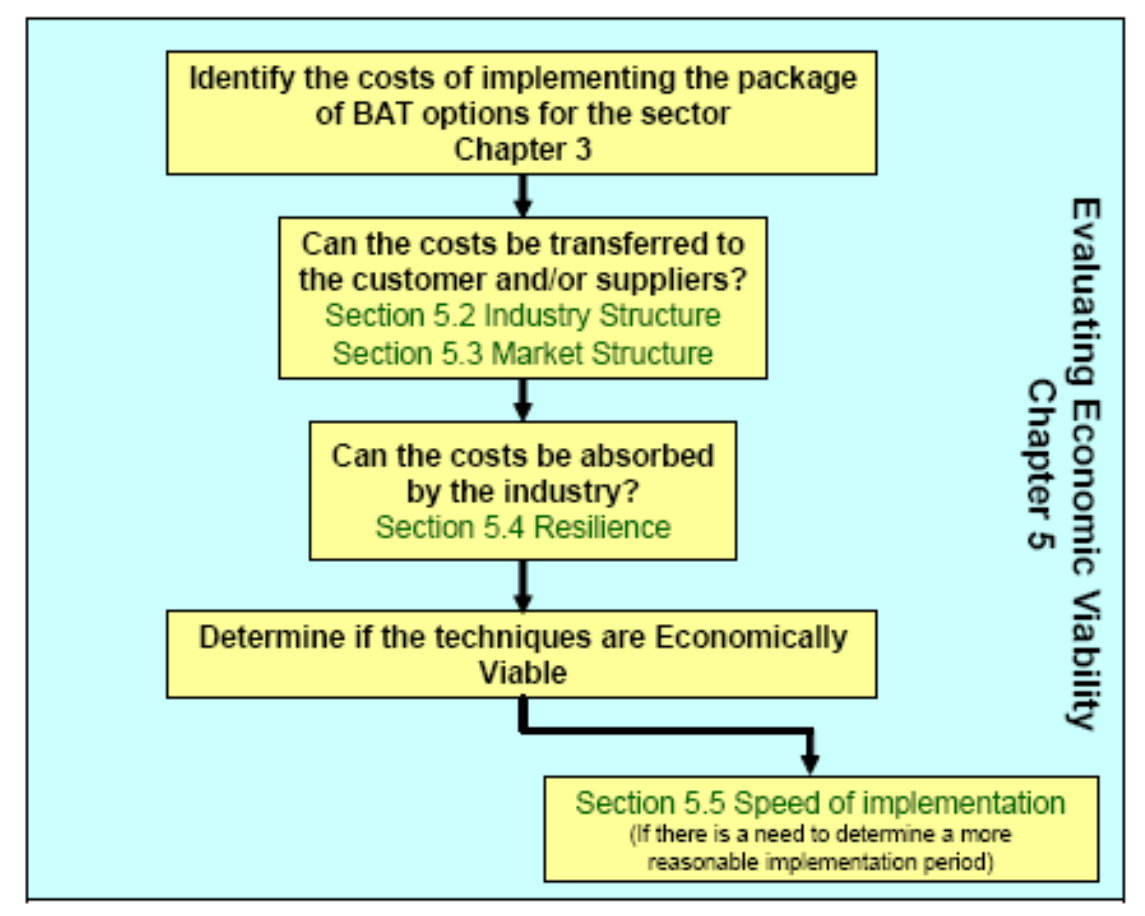

Figure 3.5. Evaluation of economic viability in the sector [2]

The socio-economic characteristics of the sector and technical characteristics of the installations in the sector can be described as industry structure. Before the determination of the BAT, if there are any constraints for implementing considered techniques, by understanding the industry structure, these constraints can be abated. For this purpose, size and number of the plants in the sector to be considered, technical characteristics of the installations, and equipment lifetimes of the plants should be evaluated. For instance, since investment costs of equipment for the implementation of BAT are generally high in value, it may be difficult for small installation to handle it. In addition to this, the type of BAT will also affect the infrastructure existing in the installation such that adopting BAT will impose additional operating costs [2]. 
Market structure is the other issue to be considered for the economic viability in the sector. Firstly, extent of the market is involved in the market structure assessment. There exist local, regional, and global markets for commodities. It is important to understand the market structure, as the power that the customer has over the price of the commodity can be determined. Price elasticity, which it used for describing how sensitive customers can change in price, is also significant such that if the prices are elastic, it can be difficult to pass the prices on the customer, so any increase in costs will affect the producer. Furthermore, competition between products is another factor that should be taken into account in the market structure [2].

Another issue is the resilience which describes the ability of the sector to absorb the increase in costs of implementing BAT, as viability remains constant. Some financial indicators such as liquidity, solvency, and profitability are provided for this analysis. Liquidity is the short-term measure that describes the ability of the company to payoff its immediate liabilities. On the other hand, solvency is the ability of the company to fulfill its obligations in long term. Lastly, a measure of the profit margins that a company enjoys can be described by the term profitability [2].

The Reference Document states that the speed of implementation of the BAT is one of the most critical issues since the IPPC Directive sets time-scale for implementing the BAT standards. Therefore, short-term, medium-term, and long-term time scales should be considered in order to determine the speed of implementation. 


\section{CHAPTER 4}

\section{SELECTED MILL}

The selected textile mill in this study is one of the largest companies in the World in terms of denim production. The factory was established in 1953, in Kayseri, in the Middle Anatolia Region of Turkey. It is an integrated establishment having yarn production, dyeing, and finishing processes with an annual capacity of 20,000 tones of cotton fiber, and 45 million meters of denim production. Yarns are produced from cotton, and then undergo dyeing and sizing processes. After sizing process, weaving process takes place in the production line. The final step is the finishing process that serves to impart to the textile the desired end-use properties [22]. Through all these wet processes in the mill, water is supplied from the wells with a daily consumption of 5,000-7,000 tones per day. Water flow in the textile mill considered is as given in Figure 4.1. Less than half of the abstracted water $(2,000-2,800$ tones per day) is used in the production processes without any treatment. The rest $(3,000-4,200$ tones per day) goes to softening by ion exchange process. The softened water from the ion exchangers is diverted to the production processes. Moreover, approximately $40 \%$ of the softened water from ion exchangers is transferred to the reverse osmosis system where water is deionised. Then, the deionised water is utilized in the cogeneration plant for steam generation. Softened water for the ion exchange process is mostly used in dyeing, sizing and finishing processes which are accepted as wet processes.

In the mill, there exists a wastewater treatment plant applying an activated sludge process. Wastewater generated from the sizing, dyeing, and finishing processes and 
also from all the facilities in the factory are treated and then discharged into the sewage system of the Kayseri Water and Sewage Authority (KASKI) with the compliance of the discharge standards.

As indicated in Chapter 1, in the project entitled as "Adaptation of IPPC Directive to a Textile Mill in Turkey", water recovery studies for the dyeing wastewaters and wastewater treatability studies for the wastewater generated from all of the processes of the mill were conducted. In the proceeding section, a short summary of the studies conducted to investigate the possible alternatives to recover water from wastewater discharges is presented. All of these treatability studies targeting at both water recovery and wastewater treatment are summarized in the following sections of this chapter indicating the water quality achieved in comparison to the discharged standard or water reuse quality criteria. 


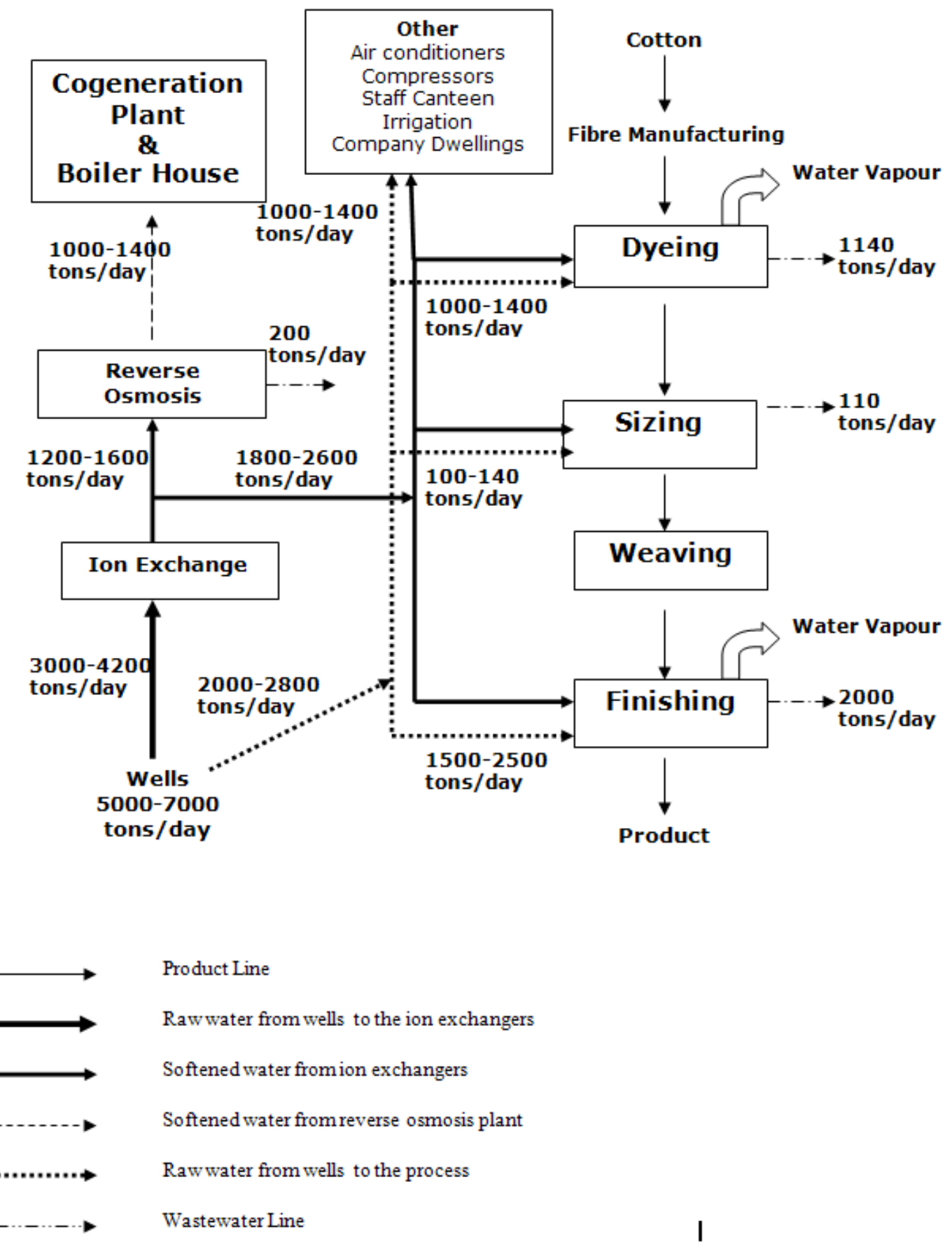

Figure 4.1. Water flow in the selected mill (as of 2005) 


\subsection{Water Recovery Studies}

In water recovery studies, different alternatives were developed to treat the wastewater generated in the dyeing unit of the selected mill, targeting at water recovery. The reason why dyeing unit was selected for the water recovery studies is the high wastewater flowrate. For this purpose, coagulation, membrane filtration, ozonation, and Fenton oxidation processes were applied to the dyeing wastewaters. These processes were investigated either as pre-treatment or treatment with the target of water reuse. Sustainable consumption of natural resources is in accordance with the main principles of the IPPC Directive.

In the proceeding sections, these process alternatives are discussed as regards their performance in achieving the desired water quality.

\subsubsection{Coagulation as a Pre-treatment for Dyeing Wastewaters}

Coagulation process was evaluated as pre-treatment alternative for dyeing rinsing wastewaters before the application of NF process in order to obtain reusable water. This process was applied to the rinsing wastewaters of the most-widely used dyeing recipes, individually and also to the mixed wastewater from the application of these recipes. Table 4.1 presents the characteristics of the abovementioned wastewaters. As shown, dyeing wastewater belonging to all recipes and consequently their mixture are very high in color and COD. In the coagulation experiments run for these wastewaters, the effluent quality presented in Table 4.2 was obtained. In these experiments, alum $\left(\mathrm{Al}_{2}\left(\mathrm{SO}_{4}\right)_{3} \cdot 18 \mathrm{H}_{2} \mathrm{O}\right)$ and ferric chloride $\left(\mathrm{FeCl}_{3} \cdot 6 \mathrm{H}_{2} \mathrm{O}\right)$ were used as coagulants at about $1,000 \mathrm{mg} / \mathrm{L}$ of dosages. 
Table 4.1. General characteristics for wastewaters of the most-widely used recipes and their mixture

\begin{tabular}{ccccc}
\hline \hline Parameters & Recipe 1 & Recipe 2 & Recipe 3 & Mixture \\
\hline \hline COD (mg/L) & $841-1,096$ & $1,571-1,787$ & $348-1,178$ & $929-1,263$ \\
\hline Color (Pt-Co) & $5,593-6,460$ & $8,600-10,660$ & $1,255-5,070$ & $5,120-6,850$ \\
\hline \hline
\end{tabular}

Table 4.2. Coagulation experiments results

\begin{tabular}{cccc}
\hline & Coagulant Type & $\begin{array}{c}\text { Effluent COD } \\
(\mathbf{m g} / \mathbf{L})\end{array}$ & $\begin{array}{c}\text { COD Removal } \\
\mathbf{( \% )}\end{array}$ \\
\hline \multirow{2}{*}{ Recipe 1 } & Alum & $370-429$ & $49-56$ \\
\cline { 2 - 4 } & Ferric chloride & $328-362$ & $57-61$ \\
\hline \multirow{2}{*}{ Recipe 2 } & Alum & $1,447-1,465$ & $18-19$ \\
\cline { 2 - 4 } & Ferric chloride & $1,197-1,233$ & $31-33$ \\
\multirow{2}{*}{ Recipe 3 } & Alum & $198-202$ & $42-43$ \\
\cline { 2 - 4 } & Ferric chloride & $198-205$ & $41-43$ \\
\hline \multirow{2}{*}{ Mixture } & Alum & $520-539$ & $42-44$ \\
\cline { 2 - 4 } & Ferric chloride & $465-483$ & $48-50$ \\
\hline \hline
\end{tabular}

As presented in Table 4.2, in coagulation experiments, it was seen that color and COD removal were achieved at high coagulant dosages. Therefore, operating costs of the process will be high due to chemical requirement and also the sludge problem that can be occur as a consequence of the chemical usage. As a result, coagulation process as pre-treatment alternative was found to be not an efficient and effective 
method. In other words, it comes to be not a proper and economical alternative for dyeing wastewaters.

\subsubsection{Membrane Filtration for Dyeing Wastewaters}

The other process applied to dyeing wastewaters in order to satisfy water recovery was the membrane filtration processes. MF, UF, and NF processes were applied to dyeing wastewaters prior to NF as coagulation.

In these studies, treatability and recovery of the wastewaters from the first postrinsing stage, composite wastewaters from all post-rinsing stages, wastewaters of the most-widely used recipes and the wastewater generated from the mixture of these recipes by membrane filtration processes were investigated. All these wastewaters had different characteristics. Table 4.1 shows the characterization of the wastewaters of the most-widely used recipes and their mixture. Moreover, COD (mg/L) and color (Pt-Co) values for the wastewaters from the first post-rinsing stage and composite wastewaters from all post-rinsing stages of dyeing are presented in Table 4.3.

Table 4.3. General characteristics for wastewaters from the first post-rinsing stage and composite wastewaters from all post-rinsing stage

\begin{tabular}{ccc}
\hline \hline Parameters & $\begin{array}{c}\text { First } \\
\text { post-rinsing stage }\end{array}$ & $\begin{array}{c}\text { Composite from all } \\
\text { post-rinsing stage }\end{array}$ \\
\hline COD (mg/L) & $1,547-1,635$ & $853-870$ \\
\hline Color (Pt-Co) & $4,824-4,950$ & $2,980-3,100$ \\
\hline \hline
\end{tabular}


From the experiments, it was determined that MF should be chosen as pre-treatment process before NF. NF was applied as the main treatment process. According to the results of these sequential applications of MF and NF, COD and color removal are as presented in Table 4.4. These removal efficiencies were achieved with an approximate permeate flux of $40 \mathrm{~L} / \mathrm{m}^{2} / \mathrm{hr}$.

Table 4.4. COD and color removal from the first post-rinsing stage and composite wastewaters from all post-rinsing stage, and the most-widely used recipes

\begin{tabular}{cccc}
\hline \hline & First & Composite from & \\
& post-rinsing & all & Most-widely \\
Parameters & stage & post-rinsing & used recipes \\
& $(\mathbf{\% )}$ & stage & $\mathbf{( \% )}$ \\
& & $\mathbf{( \% )}$ & \\
\hline \hline COD & 92 & 93 & $95-97$ \\
\hline Color & 93 & 98 & $98-99$ \\
\hline \hline
\end{tabular}

\subsubsection{Ozonation for Dyeing Wastewaters}

Wastewaters generated from the mixture of the most-widely used recipes were subjected to ozonation process. As in the previous studies, wastewater characterization experiments were initially performed. The results of these characterization studies are given in Table 4.5. 
Table 4.5. General characteristics for wastewaters subjected to ozonation process

\begin{tabular}{cc}
\hline \hline Parameters & Wastewater \\
\hline \hline COD $(\mathrm{mg} / \mathrm{L})$ & $4,560-6,120$ \\
\hline Color $(\mathrm{Pt}-\mathrm{Co})$ & $715-942$ \\
\hline
\end{tabular}

During the ozonation tests, optimum ozone dosage and contact time needed for the maximum removals of $\mathrm{COD}$ and color were determined. At the end, it was determined that in order to reduce each gram of COD, ozone requirement is 1.67 grams. This dose was the optimum dose that provides the best removal of COD and color. In Table 4.6, the COD and color removals achieved as a result of the ozonation process are presented. Although COD and color removals achieved were proper enough, conductivity of the treated wastewater remained constant at a value of 7,000 $\mu \mathrm{S} / \mathrm{cm}$, which is not satisfactory for reuse. Therefore, ozonation was found to be not a suitable alternative for water recovery from dyeing wastewaters.

Table 4.6. COD and color removal from wastewaters subjected to ozonation process

\begin{tabular}{ccc}
\hline \hline Parameters & $\begin{array}{c}\text { Removal Ratios } \\
(\mathbf{\%})\end{array}$ & Effluent Quality \\
\hline \hline COD & 60 & $1,824-2,448(\mathrm{mg} / \mathrm{L})$ \\
\hline Color & 95 & $35.8-47.1(\mathrm{Pt}-\mathrm{Co})$ \\
\hline \hline
\end{tabular}




\subsubsection{Fenton Oxidation for Dyeing Wastewaters}

Fenton oxidation process was the last treatment alternative applied to the dyeing wastewaters in order to satisfy water recovery. Ferric sulfate and hydrogen peroxide were dosed to the samples in different ranges of concentrations. Wastewater characteristics of the samples used in these experiments are illustrated in Table 4.7.

Table 4.7. General characteristics for wastewaters subjected to Fenton oxidation process

\begin{tabular}{cc}
\hline \hline Parameters & Wastewater \\
\hline \hline COD $(\mathrm{mg} / \mathrm{L})$ & 2,453 \\
\hline Color $(\mathrm{Pt}-\mathrm{Co})$ & 15,670 \\
\hline
\end{tabular}

Fenton oxidation process provided a partially effective treatment and, COD and color removals of $87 \%$ and $98 \%$, respectively, were achieved. However, the corresponding effluent quality was not satisfactory in meeting the wastewater reuse standards (Appendix A). In addition to this, the usage of ferric sulfate caused high amount of sludge production due to precipitation. Moreover, it was investigated that COD and color removal ratios would change due to the change in the wastewater characterization. Therefore, Fenton oxidation process found technically unacceptable for dyeing wastewaters for the purpose of water recovery. 


\subsection{Prioritization of Applicable Water Recovery Alternatives}

The abovementioned water recovery studies are summarized in the Table 4.8 as regards their COD and color removal efficiencies and also water recovery performance, sludge generation and clogging problem if there exists.

Table 4.8. Summary for water recovery studies

\begin{tabular}{ccccc}
\hline Criteria & Coagulation & MF + NF & Ozonation & $\begin{array}{c}\text { Fenton } \\
\text { oxidation }\end{array}$ \\
\hline $\begin{array}{c}\text { COD } \\
\text { removal }\end{array}$ & $\begin{array}{c}\text { At high coagulant } \\
\text { dosage }\end{array}$ & $95 \%$ & $60 \%$ & Not flexible \\
\hline $\begin{array}{c}\text { Color } \\
\text { removal }\end{array}$ & $\begin{array}{c}\text { At high coagulant } \\
\text { dosage }\end{array}$ & $98 \%$ & $95 \%$ & $98 \%$ \\
\hline $\begin{array}{c}\text { Water } \\
\text { recovery }\end{array}$ & None & $70 \%$ & None & None \\
\hline $\begin{array}{c}\text { Sludge } \\
\text { problem }\end{array}$ & High & Low & Low & High \\
\hline $\begin{array}{c}\text { Clogging } \\
\text { problem }\end{array}$ & None & High & None & None \\
\hline
\end{tabular}

As stated in Table 4.8, the highest COD removal was achieved by the application of membrane filtration processes. On the other side, all of the alternatives had color removals at high percentages. However, water recovery was satisfied only through the membrane filtration process. Moreover, in coagulation and Fenton oxidation processes, there exists sludge problem due to chemical usage. The other problem 
occurred was the clogging problem which is the main problem in membrane filtration processes.

The alternatives were evaluated with respect to the five screening criteria. The following screening approach has been used to select the water recovery alternative to be further assessed during the cost-benefit analysis. In this screening evaluation, each of the screening criteria was weighted depending on its assessed importance. For instance, since COD and color removal have the prior importance for the meeting the emission limits, they have the highest weights, namely 40 and 30 , respectively. Water recovery which is the main purpose of these studies followed the COD and color removals with a weight of 20. Finally, clogging problem and sludge problem had been given a weight of 5 , since they have the least importance. Moreover, each of the defined recovery alternatives was given a score between 1 and 5 depending on the assessment of the technology. In this assessment, score 5 was given to the highest and score 1 was given to the least. Then, the weights and scores have been multiplied and added in order to calculate the total score and select the most applicable alternatives. Screening of the water recovery alternatives is given in Table 4.9. 
Table 4.9. Prioritization of water recovery alternatives - Estimated scores

\begin{tabular}{cccccc}
\hline \hline Criteria & Weight & Coagulation & $\begin{array}{c}\text { MF }+ \\
\text { NF }\end{array}$ & Ozonation & $\begin{array}{c}\text { Fenton } \\
\text { oxidation }\end{array}$ \\
\hline $\begin{array}{c}\text { COD } \\
\text { removal }\end{array}$ & 40 & 1 & 5 & 3 & 2 \\
\hline $\begin{array}{c}\text { Color } \\
\text { removal }\end{array}$ & 30 & 1 & 5 & 5 & 5 \\
\hline $\begin{array}{c}\text { Water } \\
\text { recovery }\end{array}$ & 20 & 0 & 5 & 0 & 0 \\
\hline $\begin{array}{c}\text { No } \\
\text { sludge } \\
\text { problem }\end{array}$ & 5 & 0 & 5 & 5 & 0 \\
\hline $\begin{array}{c}\text { No } \\
\text { clogging } \\
\text { problem }\end{array}$ & 5 & 5 & 1 & 5 & 5 \\
\hline $\begin{array}{c}\text { TOTAL } \\
\text { (weight } \\
\text { score) }\end{array}$ & $\mathbf{1 0 0}$ & $\mathbf{0 . 9 5}$ & $\mathbf{4 . 8 0}$ & $\mathbf{3 . 2 0}$ & $\mathbf{2 . 5 5}$ \\
\hline \hline
\end{tabular}

As presented in Table 4.9, as a result of the prioritization study or scoring, membrane filtration which is composed of MF plus NF and ozonation processes appeared to be the most applicable alternative technologies pertinent for water recovery from dyeing effluents. These two alternatives should be assessed further in the cost-benefit analysis for the selection of BAT. 


\subsection{Wastewater Treatability Studies}

In the project, wastewater treatability studies were conducted for the wastewaters coming from all the units of the textile mill. In these studies, eight different treatment options were considered in both lab-scale and pilot-scale. These treatment alternatives are;

- Biological Treatment followed by MF and NF

- Membrane Bioreactor

- Ozonation

- Ozonation with Hydrogen Peroxide

- Biological Treatment followed by Ozonation

- Fenton Oxidation

- Biological Treatment followed by Fenton Oxidation

- Biological Treatment followed by Fenton Oxidation and then MF.

In this part of this thesis, outputs of the abovementioned processes are described one by one.

\subsubsection{Biological Treatment Followed by MF and NF for Mixed Wastewaters}

As it was mentioned before, the factory has its own wastewater treatment plant consisting of an activated sludge system in order to treat the mixed wastewaters from all processes. The treatment plant had been designed with a capacity of $3,600 \mathrm{~m}^{3} /$ day of flowrate. The design criteria of this wastewater treatment plant are given in Appendix B.

Treated effluent from the activated sludge unit is discharged into the sewerage system of the Kayseri Water and Sewage Authority (KASKI) according to the 
discharge standards (Table 4.10). The selected textile mill satisfies the discharge standards. These standards are given in Table 4.10.

Table 4.10. Discharge standards of KASKI

\begin{tabular}{cc}
\hline Parameters & Design Criteria \\
\hline \hline COD $(\mathrm{mg} / \mathrm{L})$ & 800 \\
\hline BOD $(\mathrm{mg} / \mathrm{L})$ & 250 \\
\hline TSS $(\mathrm{mg} / \mathrm{L})$ & 350 \\
\hline Total nitrogen $(\mathrm{mg} / \mathrm{L})$ & 40 \\
\hline Total phosphorus (mg/L) & 10 \\
\hline Oil and grease (mg/L) & 100 \\
\hline Sulphide (mg/L) & 2 \\
\hline Phenol (mg/L) & 10 \\
\hline $\mathrm{pH}$ & $6-10$ \\
\hline \hline
\end{tabular}

As can be seen from the Table 4.10, color is not a parameter that is taken into account during discharges. However, it is the one of the most important parameters in the water reuse standards (Appendix A). Therefore, NF was applied to the wastewater generated in the textile mill considered with a pre-treatment of MF in lab-scale. Wastewater taken from the entrance of the wastewater treatment was initially characterized. The characteristics are presented in Table 4.11. 
Table 4.11. General characteristics for wastewaters subjected to biological treatment followed by MF and NF

\begin{tabular}{cc}
\hline \hline Parameters & Wastewater \\
\hline \hline COD $(\mathrm{mg} / \mathrm{L})$ & $2,580-2,780$ \\
\hline Color $(\mathrm{Pt}-\mathrm{Co})$ & $2,605-2,855$ \\
\hline \hline
\end{tabular}

It was investigated from this study that biological treatment followed by membrane filtration processes can meet the reuse criteria. According to the aforementioned study, COD and color removal were achieved as approximately $90 \%$ and $100 \%$, respectively with a flux value of $37 \mathrm{~L} / \mathrm{m}^{2} / \mathrm{hr}$. Consequently, reuse potential for such treated wastewaters is very high.

\subsubsection{Membrane Bioreactor for Mixed Wastewaters}

In this project entitled as "Adaptation of IPPC Directive to a Textile Mill in Turkey", the performance of a pilot-scale MBR system for the treatment of the mixed wastewater from the wet processes (dyeing, finishing, and sizing) of the mill was investigated [42] The MBR system, containing a submerged hollow fibre membrane module in the aeration tank, was operated aerobically for about three months on-site at a continuous mode. The system was operated with a typical permeate flux of 15 $\mathrm{L} / \mathrm{m}^{2} / \mathrm{hr}$

During the entire MBR operation, the characteristics of influent wastewater was quite variable due to the variations in the textile production program and break offs during weekends for cleanings, etc. [42] (Table 4.12). 
Table 4.12. General characteristics of the influent wastewater to the pilot-scale MBR system

\begin{tabular}{cc}
\hline \hline Parameters & Wastewater \\
\hline \hline COD $(\mathrm{mg} / \mathrm{L})$ & 1,411 \\
\hline Color $(\mathrm{Pt}-\mathrm{Co})$ & 2,447 \\
\hline BOD $(\mathrm{mg} / \mathrm{L})$ & 455 \\
\hline \hline
\end{tabular}

As presented in Table 4.12, despite the high and variable BOD and COD concentrations in the influent, very high organic removals were obtained (Table 4.13). Moreover, MBR system has provided very high color removals. Throughout the entire operation, the average effluent color level was $53 \mathrm{Pt}-\mathrm{Co}$ which is well above the level achievable by activated sludge process.

Table 4.13. The performance of the MBR system

\begin{tabular}{ccc}
\hline \hline Parameters & $\begin{array}{c}\text { Removal Ratios } \\
(\%)\end{array}$ & Permeate Quality \\
\hline \hline COD & 97 & $37(\mathrm{mg} / \mathrm{L})$ \\
\hline Color & 98 & $53(\mathrm{Pt}-\mathrm{Co})$ \\
\hline BOD & 97 & $15(\mathrm{mg} / \mathrm{L})$ \\
\hline \hline
\end{tabular}




\subsubsection{Ozonation for Mixed Wastewater}

Ozonation process was applied to the textile wastewaters in three different ways. Firstly, ozonation was considered as pre-treatment technique before activated sludge process and practiced for the mixed wastewater or for the wastewater generated from all of the stages of the textile mill. Secondly, hydrogen peroxide assisted ozonation process namely peroxone process was evaluated experimentally before the activated sludge system again. The purpose of these two applications was to increase the biodegradability of the mixed wastewater before activated sludge system and or to decrease toxicity. The final alternative was the post-ozonation alternative where ozonation was experimented after the biological treatment.

First series of ozonation and peroxone experiments were applied to the wastewater samples having the same characteristics in order to be able to assess the benefit of additional hydrogen peroxide application. The characteristics of the wastewater used in these experiments are presented in Table 4.14.

Table 4.14. General characteristics for the wastewaters subjected to ozonation and peroxone tests

\begin{tabular}{cc}
\hline \hline Parameters & Wastewater \\
\hline \hline COD $(\mathrm{mg} / \mathrm{L})$ & $2,680-2,840$ \\
\hline Color $(\mathrm{Pt}-\mathrm{Co})$ & $3,920-4,200$ \\
\hline \hline
\end{tabular}

Optimum ozone dosage was evaluated as 2.33 grams per each gram of COD removed. On the other hand, optimum hydrogen peroxide dosage was determined as $1,500 \mathrm{mg} / \mathrm{L}$. However, during the experiments, no significant effect of hydrogen 
peroxide was investigated. Average removal percentages were presented in the following table. Due to high conductivity values of the effluent, the reuse of wastewater was not expected.

Table 4.15. COD and color removal from wastewaters subjected to ozonation and peroxone processes

\begin{tabular}{ccc}
\hline \hline Parameters & $\begin{array}{c}\text { Removal Ratios } \\
(\%)\end{array}$ & Effluent Quality \\
\hline \hline COD & 47 & $1,420-1,505(\mathrm{mg} / \mathrm{L})$ \\
\hline Color & 86 & $549-588(\mathrm{Pt}-\mathrm{Co})$ \\
\hline \hline
\end{tabular}

When ozonation was applied to the mixed wastewater with the composition indicated in Table 4.16 as post treatment after activated sludge system, the effluent quality presented in Table 4.17 was attained. In these experiments, the optimum ozone dosage was evaluated as 0.44 grams of ozone per each gram of COD removed from the wastewater with a COD and color removal efficiencies of approximately $50 \%$ and $98 \%$, respectively.

Table 4.16. General characteristics for wastewaters subjected to post-ozonation

\begin{tabular}{cc}
\hline \hline Parameters & Wastewater \\
\hline \hline COD $(\mathrm{mg} / \mathrm{L})$ & $743-865$ \\
\hline Color $(\mathrm{Pt}-\mathrm{Co})$ & $3,300-4,100$ \\
\hline \hline
\end{tabular}


Table 4.17. COD and color removal from wastewaters subjected to post ozonation

\begin{tabular}{ccc}
\hline \hline Parameters & $\begin{array}{c}\text { Removal Ratios } \\
(\boldsymbol{\%})\end{array}$ & Effluent Quality \\
\hline \hline COD & 50 & $372-433(\mathrm{mg} / \mathrm{L})$ \\
\hline Color & 98 & $66-82(\mathrm{Pt}-\mathrm{Co})$ \\
\hline
\end{tabular}

\subsubsection{Fenton Oxidation for Mixed Wastewater}

In this part of the wastewater treatability studies, Fenton oxidation processes were experimented in lab-scale. Similar to the ozonation processes, there were three different treatment alternatives of Fenton oxidation processes applied. These were Fenton oxidation for the wastewaters of the textile mill considered, Fenton oxidation after the activated sludge system, and Fenton oxidation followed by MF after activated sludge system. In all of these experiments, Fenton oxidation processes were found impractical due to high amount of sludge generated from the system.

\subsection{Prioritization of Applicable Wastewater Treatability Alternatives}

In this part of the thesis, the abovementioned wastewater treatability alternatives are summarized in the Table 4.18. 
Table 4.18. Summary for wastewater treatability alternatives

\begin{tabular}{|c|c|c|c|c|c|c|c|c|}
\hline Criteria & $\begin{aligned} & \mathbf{A S} \\
+ & \mathbf{M F} \\
+ & \mathbf{N F}\end{aligned}$ & MBR & $\begin{array}{l}\text { Ozonation } \\
\quad+\mathrm{AS}\end{array}$ & $\begin{array}{r}\text { Ozonation }+ \\
\mathbf{H}_{2} \mathbf{O}_{2}+\mathbf{A S}\end{array}$ & $\begin{array}{c}\text { AS } \\
+ \\
\text { Ozonation }\end{array}$ & $\begin{array}{c}\text { Fenton } \\
\text { oxidation }\end{array}$ & $\begin{array}{c}\text { AS + } \\
\text { Fenton } \\
\text { oxidation }\end{array}$ & $\begin{array}{c}\text { AS }+ \text { Fenton } \\
\text { oxidation + } \\
\text { MF }\end{array}$ \\
\hline $\begin{array}{c}\text { COD } \\
\text { removal }\end{array}$ & $90 \%$ & $97 \%$ & $47 \%$ & $47 \%$ & $50 \%$ & \multirow{5}{*}{ Not ap! } & \multirow{5}{*}{$\begin{array}{l}\text { cable due to } \\
\text { production }\end{array}$} & \\
\hline $\begin{array}{c}\text { Color } \\
\text { removal }\end{array}$ & $100 \%$ & $98 \%$ & $86 \%$ & $86 \%$ & $98 \%$ & & & \\
\hline $\begin{array}{l}\text { Water } \\
\text { recovery }\end{array}$ & High & High & None & None & None & & & igh sludge \\
\hline $\begin{array}{l}\text { Sludge } \\
\text { problem }\end{array}$ & Low & Low & Low & Low & Low & & & \\
\hline $\begin{array}{l}\text { Clogging } \\
\text { problem }\end{array}$ & Medium & Medium & None & None & None & & & \\
\hline
\end{tabular}


The same screening methodology was not performed for the wastewater treatability alternatives since similar results were found for each of the alternatives excluding Fenton processes. Therefore, the first five alternatives were assessed in the costbenefit analysis. 


\section{CHAPTER 5}

\section{COST AND BENEFIT ANALYSIS}

In this chapter, under the framework of the Reference Document on "Economics and Cross-Media Effects", both water recovery alternatives and wastewater treatability alternatives are analyzed in terms of their environmental performances or crossmedia effects and financial values.

As water recovery alternatives, NF with MF pretreatment and ozonation processes will be evaluated since these options are selected as the technically applicable ones. On the other hand, as for the treatment of the mixed wastewater; activated sludge process, MBR technology, ozonation and peroxone processes ozonation after activated sludge process, and finally $\mathrm{MF}+\mathrm{NF}$ after activated sludge process will be evaluated.

\subsection{Assumptions}

Textile wastewater is one of the industrial wastewaters that are very difficult to treat satisfactorily, due to various raw chemicals (such as dyestuffs, auxiliaries and inorganic salts) employed in textile manufacturing. These wastewaters are generally with intense color, high concentration of organic compounds, the large variations in composition [43]. As it was mentioned in the previous chapter, wastewater from the mill at which the present study was conducted was highly variable in composition in agreement with the expected characteristics. 
As it is mentioned in Chapter 3, according to the BREF, in order to compare the alternatives under the same basis, sizes and capacities of the selected alternatives should be fixed [2]. For this purpose, wastewater characterizations for dyeing wastewaters, wastewaters before and after the activated sludge system are assumed as it is stated in the Table 5.1. The assumptions are made according to the average COD and color levels determined in the previous phases of the Project.

Table 5.1. General characteristics of the wastewaters used during the cost-benefit analysis

\begin{tabular}{cccc}
\hline \hline Parameters & $\begin{array}{c}\text { Dyeing } \\
\text { Wastewaters }\end{array}$ & $\begin{array}{c}\text { Wastewaters } \\
\text { before Activated } \\
\text { Sludge System }\end{array}$ & $\begin{array}{c}\text { Wastewaters } \\
\text { after Activated } \\
\text { Sludge System }\end{array}$ \\
\hline \hline COD $(\mathrm{mg} / \mathrm{L})$ & 1,200 & 1,800 & 800 \\
\hline Color $(\mathrm{Pt}-\mathrm{Co})$ & 5,000 & 3,800 & 2,100 \\
\hline \hline
\end{tabular}

Another major assumption is made for the water recovery percentage. In the Project, one of the tasks undertaken was the determination of the wastewater distribution among the various process streams. Waste streams' flowrates were evaluated before and after the in-plant control activities which were the water recovery from dyeing wastewaters and caustic recovery from finishing wastewaters. The evaluated wastewater distributions are given in Table 5.2 [44]. While determining the following distributions, it was assumed that water recovery was achieved. 
Table 5.2. Wastewater distribution among the process streams

\begin{tabular}{ccc}
\hline \hline Process stream & $\begin{array}{c}\text { Before } \\
\text { in-plant control } \\
(\%)\end{array}$ & $\begin{array}{c}\text { After } \\
\text { in-plant control } \\
(\%)\end{array}$ \\
\hline \hline Dyeing wastewaters & 35 & 24 \\
\hline Finishing wastewaters & 45 & 31 \\
\hline Other wastewaters & 20 & 45 \\
\hline \hline
\end{tabular}

According to the abovementioned wastewater distributions before and after the inplant control studies, if it is assumed that the percentage of the other wastewaters such as sizing wastewaters was not changed, then it can be calculated that the water recovery from dyeing wastewater is approximately $70 \%$. For this reason, during the cost-benefit analysis for water recovery studies and wastewater treatability studies, water reuse percentage was taken as $70 \%$. In other words, in all the treatment alternatives by which water reuse is satisfied, permeate was assumed as $70 \%$ of the influent wastewater, whereas retentate was about $30 \%$ of the influent.

In this project, all the alternatives were performed in lab-scale or pilot scale. Therefore, in the costing analysis, the values such as flux values, optimum dosages found in the experiments will be used as they can be applied in full-scale.

\subsection{Analysis of Water Recovery Studies}

The first alternative is NF with a MF pre-treatment, and the second one is one of the advanced oxidation processes, namely ozonation. In this part of this thesis study, these alternatives will be compared with respect to their environmental effects and 
costs under the guidance of the Reference Document. In the analysis, dyeing wastewater flowrate was taken as $1,140 \mathrm{~m}^{3} /$ day (Figure 4.1).

\subsubsection{Environmental Effect Analysis}

\subsubsection{Identification of the Alternatives}

According to the Reference Document, the initial step of the analysis is the crossmedia effect determination. Cross-media effect guidelines given in the previous chapter were adopted for each of the alternatives considered. The first stage of the cross-media methodology is the identification of the alternatives. The alternatives and their performances are given in Table 5.3.along with assumptions made. Influent COD concentration and influent color concentration was assumed as the average values gathered from the experimental studies.

Table 5.3. Identification of the water recovery alternatives

\begin{tabular}{cccccc}
\hline \hline $\begin{array}{c}\text { Alternative } \\
\text { Options }\end{array}$ & $\begin{array}{c}\text { Influent } \\
\text { COD }\end{array}$ & $\begin{array}{c}\text { Influent } \\
\text { Color }\end{array}$ & $\begin{array}{c}\text { COD } \\
\text { Removal }\end{array}$ & $\begin{array}{c}\text { Color } \\
\text { Removal } \\
(\mathbf{P t}-\mathbf{L})\end{array}$ & $\begin{array}{c}\text { Water } \\
\text { Recovery }\end{array}$ \\
\hline \hline MF + NF & 1,200 & 5,000 & 95 & 98 & $\mathbf{( \% )}$ \\
\hline Ozonation & 1,200 & 5,000 & 60 & 95 & - \\
\hline \hline
\end{tabular}




\subsubsection{Inventory of Consumptions and Emissions}

The presentation of the inventory of consumptions and emissions is the next step. For this purpose, energy consumption of each alternative was determined at first. These determinations were made based on the literature values. The specific energy consumption values of the alternative are presented in Table 5.4.

Table 5.4. Energy consumptions of the water recovery alternatives [45]

\begin{tabular}{ccc}
\hline \hline Alternatives & $\begin{array}{c}\text { Specific energy } \\
\text { consumption }\end{array}$ & $\begin{array}{c}\text { Energy } \\
\text { Consumption } \\
\text { (kWh) }\end{array}$ \\
\hline \hline $\mathrm{MF}\left(\mathrm{kWh} / \mathrm{m}^{3}\right)$ & 0.40 & \\
\hline $\mathrm{NF}\left(\mathrm{kWh} / \mathrm{m}^{3}\right)$ & 5.30 & 6,498 \\
\hline Membrane Filtration Total & 5.70 & 37,650 \\
\hline Ozonation $(\mathrm{kWh} / \mathrm{kg}$ ozone) & $13.20-19.80$ & \\
\hline
\end{tabular}

Specific energy consumption considered in estimations

By using the specific energy consumption figures, electricity to be used for the alternatives were estimated. As can be depicted from Table 5.4, estimated energy consumption figures are $6,498 \mathrm{kWh}$ per day for membrane filtration $(\mathrm{MF}+\mathrm{NF})$ and $37,650 \mathrm{kWh}$ per day for ozonation based on an average specific energy consumption of $16.5 \mathrm{kWh} / \mathrm{kg}$ ozone. The difference between the energy consumptions is nearly six times. This is primarily due to the high energy need for ozone generation. On the other hand, membrane filtration operations need energy only for their pumping equipments. 
The Reference Document also requires the assessment of the environmental impacts of energy generation. In order to evaluate these impacts, in Annex 8 of the Reference Document, multiplication factors that have been derived for the emissions of $\mathrm{SO}_{2}$, $\mathrm{CO}_{2}$, and $\mathrm{NO}_{2}$ and also for the consumption of oil, gas, and coal per GJ of electricity generation are given. According to the document, for the Europe, the average fuel use and emissions released to generate 1 GJ of electricity are as listed in Table 5.5.

Table 5.5. Average fuel use and emissions released to create 1 GJ of electricity [2]

\begin{tabular}{cccc}
\hline \hline & \multicolumn{1}{c}{ Type } & Unit & Value \\
\hline \hline \multirow{4}{*}{ Fuel } & Primary energy & $\mathrm{GJ}$ & 2.57 \\
\cline { 2 - 4 } & Oil & $\mathrm{kg}$ & 9.01 \\
\cline { 2 - 4 } & $\mathrm{Gas}$ & $\mathrm{m}^{3}$ & 6.92 \\
\cline { 2 - 4 } & Coal & $\mathrm{kg}$ & 15.7 \\
\cline { 2 - 4 } Emissions & Brown coal & $\mathrm{kg}$ & 34.6 \\
\cline { 2 - 4 } & $\mathrm{SO}_{2}$ & $\mathrm{~kg}$ & 0.10 \\
\cline { 2 - 4 } & $\mathrm{CO}_{2}$ & $\mathrm{~kg}$ & 117 \\
\cline { 2 - 4 } & $\mathrm{NO}_{2}$ & $\mathrm{~kg}$ & 0.16 \\
\hline \hline
\end{tabular}

By using the abovementioned multiplication factors, emissions of $\mathrm{SO}_{2}, \mathrm{CO}_{2}$ and $\mathrm{NO}_{2}$ from the alternatives considered for water recovery were calculated and the results given in the Table 5.6 were obtained. As can be seen from the table, estimated mass generations of $\mathrm{SO}_{2}$ and $\mathrm{NO}_{2}$ were negligible as compared to the mass generation of $\mathrm{CO}_{2}$. Therefore, only the estimated mass of $\mathrm{CO}_{2}$ emission was considered as the mass of pollutant released to the air (Table 5.7). Since the energy used in the ozonation process was higher than the energy used in membrane filtration processes, 
indirect emissions due to the application of ozonation were found to be higher than the ones for the other processes. (In these calculations, 1 GJ was taken as 277.78 $\mathrm{kWh}$ ).

Table 5.6. Calculated emission values released from the alternative options

\begin{tabular}{cccc}
\hline \hline Alternative options & Type & Unit & Value \\
\hline \hline \multirow{3}{*}{$\mathrm{MF}+\mathrm{NF}$} & $\mathrm{SO}_{2}$ & $\mathrm{~kg} /$ day & 2.34 \\
\cline { 2 - 4 } & $\mathrm{CO}_{2}$ & $\mathrm{~kg} /$ day & 2,737 \\
\cline { 2 - 4 } & $\mathrm{NO}_{2}$ & $\mathrm{~kg} /$ day & 3.74 \\
\hline \hline \multirow{2}{*}{ Ozonation } & $\mathrm{SO}_{2}$ & $\mathrm{~kg} /$ day & 13.54 \\
\cline { 2 - 4 } & $\mathrm{CO}_{2}$ & $\mathrm{~kg} /$ day & 15,846 \\
\hline $\mathrm{NO}_{2}$ & $\mathrm{~kg} /$ day & 21.67 \\
\hline
\end{tabular}

Table 5.7. Mass of pollutants released to air

\begin{tabular}{cc}
\hline \hline Alternative Options & $\begin{array}{c}\text { Mass of pollutant } \\
\text { (kg/day) }\end{array}$ \\
\hline \hline MF + NF & 2,737 \\
\hline Ozonation & 15,846 \\
\hline \hline
\end{tabular}

Additionally, the effluents from membrane filtration process are planned to be reused in the dyeing stage in the textile mill. In addition to this, the rejected stream which appeared as $30 \%$ of the effluent from the membrane filtration process would be treated in the existing wastewater treatment plant of the textile mill considered. 
Therefore, mass of pollutants released to aquatic environment from membrane filtration alternative would not be directly from the membrane filtration processes, it would be released due to the treatment of the rejected stream in the activated sludge process. With a flowrate of $1,140 \mathrm{~m}^{3} /$ day and COD of $1,200 \mathrm{mg} / \mathrm{L}$, the mass of the pollutant in the rejected stream was calculated as $68 \mathrm{~kg}$ per day after $95 \% \mathrm{COD}$ removal by membrane filtration. On the other hand, ozonation effluents are also thought to be discharged to the existing activated sludge system of the textile mill. Therefore, similar to the membrane filtration system, mass of pollutants released to aquatic environment due to the ozonation process would be originating from the pollutants in the ozonated effluent going into activated sludge process. Ozonated effluent having a flowrate of $1,140 \mathrm{~m}^{3} /$ day was with a COD load of $547 \mathrm{~kg} / \mathrm{day}$ after $60 \%$ removal during ozonation.

In the Reference Document, it is stated that water consumptions and waste productions of each alternative should be evaluated. In this part of the thesis, both alternatives do not consume raw water. During membrane filtration processes, the need of water for back-washing operation can be supplied from water recovered.

In the Reference Document, for the inventory of wastes generated from each of the alternative option under consideration, waste classification given below is suggested;

- Inert wastes,

- Non-hazardous wastes,

- Hazardous wastes.

Thus, for each alternative, possible generation of all these waste types was considered. It was assumed that both of the recovery options will produce neither inert wastes nor non-hazardous wastes. In addition, the effluents of each of the alternatives were not thought as inert wastes or non-hazardous waste since they 
would be treated further in the existing wastewater treatment plant. However, sludges produced from these options were considered as hazardous waste. The calculated sludge amount which would reflect hazardous waste in the cross-media effect analysis is given in Table 5.8. These quantities were estimated based on the values given in Table 5.3 for $1,140 \mathrm{~m}^{3} /$ day of wastewater flowrate with assuming yield coefficient as 0.5 .

Table 5.8. Hazardous waste generation for the water recovery alternatives

\begin{tabular}{cc}
\hline \hline Alternative Options & $\begin{array}{c}\text { Hazardous Waste } \\
\text { (kg/day) }\end{array}$ \\
\hline MF + NF & 650 \\
\hline Ozonation & 410 \\
\hline \hline
\end{tabular}

\subsubsection{Cross-Media Effects of the Alternatives}

The next step after the establishment of inventory of the emissions is the calculation of the cross-media effects of each alternative under consideration. Six environmental themes were assessed for the alternatives. These are;

- Human toxicity

- Global warming

- Aquatic toxicity

- Eutrophication

- Ozone depletion

- Photochemical ozone creation potential 
Alternatives considered for the water recovery studies in the selected mill have no direct cause on the abovementioned environmental themes. However, due to indirect effects of emissions released from the energy consumptions, cross-media effects were assessed for both of the recovery alternatives. Appendix $\mathrm{C}$ includes a sample working sheet developed by using Microsoft Excel 2007 for cross-media effect assessments (Figure C.2).

Human toxicity is one of the indicators for comparing the alternative options in terms of their environmental impacts. In order to evaluate human toxicity potential, mass of toxicity causing pollutant released to air was divided to the toxicity factor of the pollutant. Toxicity factors have been given in Annex 1 of the Reference Document on "Economics and Cross-Media Effects". Toxicity factors listed are only used for estimating the general toxicity effects. Moreover, they are derived from German occupational exposure limits, divided by the respective figure for lead [2].

Using the toxicity factors, human toxicity potentials are estimated as kilogram of lead equivalent. The suggested toxicity factors for $\mathrm{SO}_{2}$ and $\mathrm{NO}_{2}$ are 13 and 95, respectively. By dividing the calculated emission values for given in Table 5.6 into these toxicity potentials, the human toxicity potentials for the water recovery alternatives were evaluated and the values are given in the Table 5.9 below.

Table 5.9. Human toxicity potentials of the water recovery alternatives

\begin{tabular}{cc}
\hline \hline Alternative Options & $\begin{array}{c}\text { Human Toxicity } \\
\text { (kg lead equivalents) }\end{array}$ \\
\hline MF + NF & 0.22 \\
\hline Ozonation & 1.27 \\
\hline \hline
\end{tabular}


The second environmental theme is the global warming which is the gradual increase in the average measured temperature of Earth due to the greenhouse gases such as carbon dioxide $\left(\mathrm{CO}_{2}\right)$. In other words, Sun's energy is trapped in the atmosphere because of the increasing quantity of the greenhouse gases [2]. Therefore, it is also important to predict the global warming potentials of the alternatives.

The same as the toxicity potentials for each of the emissions, global warming potentials for each of the emissions are indicated in the Annex 2 to the Reference Document. These potentials are published by IPCC (Intergovernmental Panel on Climate Change). Total global warming potentials of the alternatives considered were evaluated by the summation of the global warming potential of each greenhouse gas released.

For the evaluation of the water recovery alternatives, $\mathrm{CO}_{2}$ is considered to be the only greenhouse gas to be released due to energy usage for the alternatives. According to the Reference Document, global warming potential of $\mathrm{CO}_{2}$ is stated as 1. The masses of $\mathrm{CO}_{2}$ emissions those were determined in the inventory study in Table 5.6 were multiplied by 1 and illustrated as the global warming potential for each alternative option. The units of these values were expressed as kilograms of $\mathrm{CO}_{2}$ equivalent. Table 5.10 shows the indirect global warming potentials of the water recovery alternatives evaluated accordingly. 
Table 5.10. Global warming potentials of the water recovery alternatives

\begin{tabular}{cc}
\hline \hline Alternative Options & $\begin{array}{c}\text { Global warming } \\
\text { (kg CO} \mathbf{~ e q u i v a l e n t s ) ~}\end{array}$ \\
\hline \hline MF + NF & 2,737 \\
\hline Ozonation & 15,846 \\
\hline
\end{tabular}

According to the Reference Document, the third environmental theme that should be considered for the alternatives is the aquatic toxicity. As indicated before, since there should be no effluent discharge to the aquatic environment from water recovery alternative, aquatic toxicity would not be a consideration. For that reason, in the cross-media effect determination, aquatic toxicity was not estimated.

Acidification is the next environmental theme that needs to be taken into account in the cross-media effect determination. Sulfur dioxide $\left(\mathrm{SO}_{2}\right)$, ammonia $\left(\mathrm{NH}_{4}\right)$ and oxides of nitrogen $\left(\mathrm{NO}_{\mathrm{X}}\right)$ are the most significant acidifying gases. The impacts of these gases in terms of acidification include damage to forests, lakes, and ecosystems, deterioration of fish populations and erosion of buildings and historical monuments. Therefore, it is a significant indicator for the purpose of comparing the alternative options. The calculation of the acidification potential is the same as the calculation of the global warming potential. Acidification potentials for each pollutant are given in Annex 4 of the Reference Document in sulfur dioxide equivalents. Considering Annex 4, acidification potential of $\mathrm{SO}_{2}$ is 1 whereas it is 0.5 for $\mathrm{NO}_{2}$. According to the emissions values of $\mathrm{SO}_{2}$ and $\mathrm{NO}_{2}$ illustrated in Table 5.6, the calculated emission values of both were multiplied with the acidification potentials and summed up in order to find the total acidification potential. Table 5.11 indicates the acidification potentials of the water recovery alternatives under consideration. 
Table 5.11. Acidification potentials of the water recovery alternatives

\begin{tabular}{cc}
\hline \hline Alternative Options & $\begin{array}{c}\text { Acidification } \\
\text { (kg SO} \mathbf{~} \text { equivalents) }\end{array}$ \\
\hline \hline MF + NF & 4.21 \\
\hline Ozonation & 24.38 \\
\hline \hline
\end{tabular}

Eutrophication and ozone depletion are the two other important issues that need to be taken under consideration while assessing the cross-media effects. Eutrophication is the undesired increases in biomass production in aquatic or terrestrial ecosystems caused by high nutrient inputs which results in algal formations and subsequent oxygen-consuming degradation processes causing the death of the aquatic environment (Eutrophication). In this thesis, eutrophication can be neglected from the cross-media effect assessment, since both of the water recovery alternative processes, namely membrane filtration processes and ozonation, do not release pollutants to the aquatic environment.

Another environmental theme that cannot be determined is the ozone depletion. Some substances emitted by human activities lead to the breakdown of stratospheric ozone. This in turn causes a larger fraction of the sun's UV-B radiation to reach the earth's surface than in their absence. Moreover, this can have harmful effects on human health, animal health, terrestrial and aquatic ecosystems, biochemical cycles, as well as on materials [46]. In this study, the emissions released due to the energy consumptions of the proposals have no potential of ozone depletion.

The final cross-media effect is the photochemical ozone creation potential. It can be defined as the formation of reactive substances (mainly ozone), which are harmful to human health and ecosystems, and which may damage crops. Precursors of photo- 
oxidants are mainly VOCs, $\mathrm{CO}, \mathrm{SO}_{2}$ and $\mathrm{NO}_{\mathrm{X}}$ [46]. The structure and reactivity of these photo-oxidants affect their ozone creation potential. For that reason, UNECE 'Protocol to Abate Acidification, eutrophication, and Ground Level Ozone' convention proposed the concept of using photochemical ozone creation potential [2]. In this thesis, photochemical ozone creation potential was determined for $\mathrm{SO}_{2}$ and $\mathrm{NO}_{2}$ emissions released from the energy consumptions of the water recovery alternatives. In Annex 7 of the Reference Document, photochemical ozone creation potentials of these individual pollutants are stated as 0.048 for $\mathrm{SO}_{2}$ and 3.8 for $\mathrm{NO}_{2}$. In order to evaluate the total photochemical ozone creation potential, these factors were multiplied by the mass of the pollutants and the summation of the results of the multiplication gave the total potential expressed as kilogram of ethylene equivalent. Table 5.12 below shows these results. 
Table 5.12. Photochemical ozone creation potentials of the water recovery alternatives

\begin{tabular}{cc}
\hline \hline Alternative Options & $\begin{array}{c}\text { Photochemical } \\
\text { ozone creation } \\
\text { (kg ethylene equivalents) }\end{array}$ \\
\hline \hline MF + NF & 14.34 \\
\hline Ozonation & 83.00 \\
\hline \hline
\end{tabular}

All the cross-media effects were assessed under the framework of the Reference Document for each of the alternative options under consideration in order to compare them. It can be concluded from the results of the assessment that membrane filtration processes have fewer effects on the environment than ozonation processes (Table 5.13). Therefore, membrane filtration process namely NF after the application of MF can be accepted as the least environmentally damaging option for water recovery from dyeing wastewaters in textile industry. All the calculated cross-media effects are given in Table 5.13. 
Table 5.13. Cross-media effects of the water recovery alternatives

\begin{tabular}{|c|c|c|c|c|c|c|}
\hline $\begin{array}{c}\text { Alternative } \\
\text { Options }\end{array}$ & $\begin{array}{c}\text { Human } \\
\text { Toxicity } \\
\text { (kg lead } \\
\text { equivalents) }\end{array}$ & $\begin{array}{c}\text { Global } \\
\text { warming } \\
\text { (kg CO} \\
\text { equivalents) }\end{array}$ & $\begin{array}{l}\text { Acidification } \\
\qquad\left(\mathrm{kg} \mathrm{SO}_{2}\right. \\
\text { equivalents) }\end{array}$ & $\begin{array}{c}\text { Eutrophication } \\
\qquad\left(\mathrm{kg} \mathrm{PO}_{4}^{-3}\right. \\
\text { equivalents) }\end{array}$ & $\begin{array}{c}\text { Ozone } \\
\text { Depletion } \\
\text { (kg CFC } \\
\text { equivalent) }\end{array}$ & $\begin{array}{c}\text { Photochemical } \\
\text { ozone creation } \\
\text { (kg ethylene } \\
\text { equivalents) }\end{array}$ \\
\hline $\mathrm{MF}+\mathrm{NF}$ & 0.22 & 2,737 & 4.21 & - & - & 14.34 \\
\hline Ozonation & 1.27 & 15,846 & 24.38 & - & - & 83.00 \\
\hline
\end{tabular}




\subsubsection{Financial Analysis}

After the assessment of the environmental performances of the alternatives, these alternatives were evaluated in terms of economic considerations. Each step of the costing methodology stated in the Reference Document was applied to the alternatives under consideration for water recovery. In this part of the thesis, firstly cost components such as investment costs and operating costs of the processes are discussed. Then, the calculated cost figures are introduced. Furthermore, in this thesis, cost data for the alternative options was derived from published information such as reports, journals, websites, and conference proceedings. Firstly, investment costs and operating costs were determined for each of the alternatives. According to the cost information gathered, in order to manipulate them some financial concepts were evaluated. A sample working sheet, developed by using Microsoft Excel 2007, for financial analysis in water recovery studies is given in Appendix C (Figure C.3).

\subsubsection{Investment Costs}

\section{Part I. Membrane Filtration Processes}

As it is mentioned, the application of membrane processes to textile wastewater treatment and reuse has been proved effective from a technical point of view in addition to their environmental performances. However, these processes have high investment and operating costs compared to conventional systems.

The investment costs for NF application were estimated by using the formulas stated in Table 2.8. They can be classified as civil investments, mechanical investments, membrane investments, and additional investments. Civil investment includes buildings where the installation is housed. In addition, depreciation period for these 
investments is assumed as 30 years. On the other hand, mechanical investments are composed of costs of pumps, and piping with a depreciation period of 15 years.

The other important investment cost component is the membrane costs. The membrane lifetime was estimated at 5 years. In the lab-scale experiments, NF 270 module which has nominal active surface area of $37 \mathrm{~m}^{2}$ was used in order to recover water from the system [47]. Moreover, the estimated unit cost of this membrane module is 780 EUR, which costs about 1,225 USD with an exchange rate of 1.57 EUR/USD [48]. Beside these, NF was applied to the dyeing textile wastewaters with a flux of approximately $40 \mathrm{~L} / \mathrm{m}^{2}-\mathrm{hr}$ in lab-scale experiments. For that reason, for the full-scale implementation of NF, the flux value was assumed as the same. As a result, the required total membrane area was determined as $1,187.5 \mathrm{~m}^{2}$. Hence, the system needs approximately 32 modules of NF membrane.

According to the Table 2.8, $\mathrm{Q}\left(\mathrm{m}^{3} / \mathrm{hr}\right)$ is the feed flow; $\mathrm{n}$ is the number of membrane modules. The calculated investment costs for NF application are given in the Table 5.14 in EUR. The exchange rate is 1.57 EUR/USD in these calculations.

Table 5.14. Investment costs for NF process

\begin{tabular}{cc}
\hline \hline Components & Investment Costs \\
\hline \hline Civil investments & 80,710 \\
\hline Mechanical investments & 125,183 \\
\hline Membrane investments & 39,303 \\
\hline Additional investments & 49,039 \\
\hline \hline TOTAL (EUR) & $\mathbf{2 9 4 , 2 3 5}$ \\
\hline \hline TOTAL (USD) & $\mathbf{4 6 1 , 9 4 9}$ \\
\hline \hline
\end{tabular}


As it is mentioned, the flow rate of the dyeing wastewaters for these cost analysis was estimated at $1,140 \mathrm{~m}^{3}$ per day. Therefore, the unit investment cost for NF application can be calculated as 405 USD per each $\mathrm{m}^{3}$ of wastewater recovered.

According to the literature survey, the unit investment cost for the application of MF before NF is estimated at 150 USD per $\mathrm{m}^{3}$ of wastewater treated. For the determination of the MF investment costs, this value was used. It was assumed that since MF and NF processes need to be applied sequentially, civil investment for the MF process was neglected. As a result, the investment need for performing MF before NF process for dyeing wastewater with a flowrate of $1,140 \mathrm{~m}^{3}$ per day was evaluated as 171,000 USD. Consequently, the total investment cost for membrane filtration alternative was estimated at 632,949 USD.

\section{Part II. Ozonation Process}

In the case of ozonation application, the main items of equipment required are the reactor and the ozone generator. The investment need for such a system can be calculated from the formula stated in Figure 2.4 which is a function of ozone production required for treatment [12].

Prtce $=1,719.5 * q^{* 0.6148}$

where;

q : Ozone requirement per hour,

Price : Price of the ozonation process equipment cost in EUR. 
In the lab-scale experiments, with an average COD value of $1,200 \mathrm{mg} / \mathrm{L}$ and $95 \%$ of COD removal where the flowrate was $1,140 \mathrm{~m}^{3} /$ day, it was calculated that COD removed was $54,150 \mathrm{gr} / \mathrm{h}$. In addition to this, it was also observed that for each gram of COD removal, ozone requirement of the system would be 1.67 grams in the water recovery studies conducted for dyeing wastewaters. Therefore, the hourly ozone requirement was calculated as $90,431 \mathrm{gr} / \mathrm{h}$. By using the equation given above, the price of the ozonation system equipment was evaluated as 1,905,752 EUR.

In this thesis, the civil investments for such an ozonation system was assumed to be the same as the civil investments calculated in membrane filtration processes, since the flowrate and the initial COD values were the same. As a result, civil investment need was assumed as 80,710 EUR. Then, the total investment cost for ozonation system for dyeing wastewaters was estimated at 1,986,462 EUR which corresponds to $3,118,746$ USD with and exchange rate of $1.57 \mathrm{EUR} / \mathrm{USD}$.

Consequently, the comparison between the investment costs of the two alternatives, namely membrane filtration processes and ozonation process is as presented in Table 5.15. As it can be concluded from the results that investment need for membrane filtration processes are nearly five times less than the need for the ozonation process.

Table 5.15. Investment costs of the water recovery alternatives

\begin{tabular}{cc}
\hline \hline Alternative Options & $\begin{array}{c}\text { Investment Costs } \\
\text { (USD) }\end{array}$ \\
\hline \hline MF + NF & 632,949 \\
\hline Ozonation & $3,118,746$ \\
\hline \hline
\end{tabular}




\subsubsection{Operating Costs}

After the investment cost determination, operating costs of the alternative options were analyzed. Operating costs are composed of six components which are;

- Energy costs,

- Depreciation costs,

- Maintenance costs,

- Quality control cost,

- Operating of installation,

- Chemical costs.

\section{Part I. Membrane Filtration Processes}

For the estimation of the energy costs, in the cross-media effects determination part of the thesis, specific energy consumptions were estimated for each of the alternative option under consideration. Specific energy consumption for NF was determined as $5.30 \mathrm{kWh}$ per $\mathrm{m}^{3}$ of wastewater. According to the information gathered from the selected mill, the average electricity cost is about 0.072 YTL per kWh which corresponds to $0.058 \mathrm{USD}$ per $\mathrm{kWh}$ with an exchange rate of $1.25 \mathrm{USD} / \mathrm{YTL}$. The selected textile mill generates energy with its co-generation unit and also buys electricity from city electric network. Therefore, energy cost was calculated as 0.305 USD per $\mathrm{m}^{3}$ of recovered wastewater.

Depreciation is the decreasing value of the asset to the owner [49]. In this thesis, the simplest method was used to determine the depreciation which is the straight-line method. This method assumes that a constant amount is depreciated each year over the depreciable life of the asset; hence, the book value of that asset decreases linearly with time. It is stated above that depreciation period for civil, mechanical, membrane 
investments are 30 years, 15 years, and 5 years, respectively. For that reason, the depreciation cost of NF application was calculated as 0.071 USD per $\mathrm{m}^{3}$ of wastewater. Furthermore, maintenance costs, quality control costs, and operating of installation were taken as the $2 \%$ of the total investment cost. For this reason, each of these operating cost components was calculate as 0.022 USD per $\mathrm{m}^{3}$ of wastewater.

The final operating cost component is the chemical cost. Chemical demand for NF was assumed as 0.020 EUR (about 0.031 USD) per $\mathrm{m}^{3}$ of wastewater treated [34]. Under the framework of the operating costs mentioned above, the summary of the operating costs are given in Table 5.16.

Table 5.16. Operating costs for NF application

\begin{tabular}{cc}
\hline Components & $\begin{array}{c}\text { Operating Costs } \\
\left(\mathbf{U S D} / \mathbf{m}^{\mathbf{3}}\right)\end{array}$ \\
\hline Energy & 0.31 \\
\hline Depreciation & 0.07 \\
\hline Maintenance & 0.02 \\
\hline Quality control & 0.02 \\
\hline Operating of installation & 0.02 \\
\hline Chemical & 0.03 \\
\hline \hline TOTAL & $\mathbf{0 . 4 7}$ \\
\hline \hline
\end{tabular}

The same procedure was followed in order to determine the operating cost of MF application which thought to be implemented after NF process. The specific energy 
requirement for MF was determined as $0.40 \mathrm{kWh}$ per $\mathrm{m}^{3}$. Thus, the energy cost was calculated as 0.023 USD per each $\mathrm{m}^{3}$ of wastewater treated. Moreover, the other cost components were determined as given in Table 5.17.

Table 5.17. Operating costs for MF application

\begin{tabular}{cc}
\hline Components & $\begin{array}{c}\text { Operating Costs } \\
\left(\mathbf{U S D} / \mathbf{m}^{\mathbf{3}}\right)\end{array}$ \\
\hline \hline Energy & 0.02 \\
\hline Depreciation & 0.04 \\
\hline Maintenance & 0.01 \\
\hline Quality control & 0.01 \\
\hline Operating of installation & 0.01 \\
\hline Chemical & 0.03 \\
\hline \hline TOTAL & $\mathbf{0 . 1 2}$ \\
\hline \hline
\end{tabular}

Consequently, the overall operating cost for the membrane filtration application for dyeing wastewater generated in the selected mill for water recovery purposes was evaluated as 0.60 USD per each $\mathrm{m}^{3}$ of wastewater recovered.

\section{Part II. Ozonation Process}

Similarly, energy cost was evaluated for ozonation process where the specific energy consumption of the system was determined as $33 \mathrm{kWh}$ per $\mathrm{m}^{3}$ of wastewater. Then, energy cost was calculated as 1.90 USD per $\mathrm{m}^{3}$ by taking the energy price as 0.058 USD per $\mathrm{kWh}$. Since the equipments used in the ozonation process are mechanical 
equipments, the depreciation period was assumed as 15 years. Moreover, maintenance, quality control cost, and operating of installation costs were again assumed as $2 \%$ of the total investment cost. The overall operating cost and its components are illustrated in Table 5.18.

Table 5.18. Operating costs for ozonation application

\begin{tabular}{cc}
\hline Components & $\begin{array}{c}\text { Operating Costs } \\
\left(\mathbf{U S D} / \mathbf{m}^{\mathbf{3}}\right)\end{array}$ \\
\hline \hline Energy & 1.90 \\
\hline Depreciation & 0.50 \\
\hline Maintenance & 0.15 \\
\hline Quality control & 0.15 \\
\hline Operating of installation & 0.15 \\
\hline TOTAL & $\mathbf{2 . 8 5}$ \\
\hline
\end{tabular}

As is the same case in investment cost, ozonation is much more expensive process than membrane filtration processes in terms of operating cost. The comparison table regarding operating costs is given below. 
Table 5.19. Operating costs of the water recovery alternatives

\begin{tabular}{cc}
\hline Alternative Options & $\begin{array}{c}\text { Operating Costs } \\
\left(\mathbf{U S D} / \mathbf{m}^{\mathbf{3}}\right)\end{array}$ \\
\hline \hline MF + NF & 0.60 \\
\hline Ozonation & 2.85 \\
\hline \hline
\end{tabular}

\subsubsection{Revenues and Avoided Costs}

Furthermore, revenues and some costs being avoided were delivered from the application of the alternatives under consideration. These were due to water recovery and the reduction in the wastewater discharge. The selected mill has been paying 1 YTL for each $\mathrm{m}^{3}$ of water used, and also have been paying 1 YTL for each $\mathrm{m}^{3}$ of wastewater discharged [50]. By means of membrane filtration, as it was stated approximately $70 \%$ of water recovery can be achieved. It was assumed that $798 \mathrm{~m}^{3}$ of water can be recovered, and also $798 \mathrm{~m}^{3}$ of water was not discharged daily. Therefore, $1,596 \mathrm{~m}^{3}$ of water which corresponds to 1,596 YTL was avoided. With an exchange rate of $1.25 \mathrm{USD} / \mathrm{YTL}$, the avoided cost was determined as 466,032 USD per year. From these cost components, cash flow was assessed for 15 years of economic life (Table 5.20).

On the other hand, application of ozonation process has no revenues, since water recovery was not achieved in the lab-scale studies. Cash flow was also assessed for the ozonation process for 15 years of economic life time and illustrated in Table 5.21 . 
Table 5.20. Cash flow (USD) assessment for membrane filtration alternative

\begin{tabular}{|c|c|c|c|c|c|c|c|c|c|c|c|c|c|c|c|}
\hline YEARS & 2008 & 2009 & 2010 & 2011 & 2012 & 2013 & 2014 & 2015 & 2016 & 2017 & 2018 & 2019 & 2020 & 2021 & 2022 \\
\hline \multicolumn{16}{|l|}{ Revenues } \\
\hline $\begin{array}{l}\text { Water } \\
\text { Recovery }\end{array}$ & 0 & 233,016 & 233,016 & 233,016 & 233,016 & 233,016 & 233,016 & 233,016 & 233,016 & 233,016 & 233,016 & 233,016 & 233,016 & 233,016 & 233,016 \\
\hline $\begin{array}{l}\text { Reduction in } \\
\text { WW }\end{array}$ & 0 & 233,016 & 233,016 & 233,016 & 233,016 & 233,016 & 233,016 & 233,016 & 233,016 & 233,016 & 233,016 & 233,016 & 233,016 & 233,016 & 233,016 \\
\hline $\begin{array}{l}\text { TOTAL } \\
\text { Revenue }\end{array}$ & 0 & 466,032 & 466,032 & 466,032 & 466,032 & 466,032 & 466,032 & 466,032 & 466,032 & 466,032 & 466,032 & 466,032 & 466,032 & 466,032 & 466,032 \\
\hline $\begin{array}{l}\text { Expenditures } \\
\text { Investment } \\
\text { Cost }\end{array}$ & 632,949 & 0 & 0 & 0 & 0 & 0 & 0 & 0 & 0 & 0 & 0 & 0 & 0 & 0 & 0 \\
\hline $\begin{array}{l}\text { Operating } \\
\text { Cost }\end{array}$ & 0 & 200,772 & 200,772 & 200,772 & 200,772 & 200,772 & 200,772 & 200,772 & 200,772 & 200,772 & 200,772 & 200,772 & 200,772 & 200,772 & 200,772 \\
\hline $\begin{array}{l}\text { TOTAL } \\
\text { Expenditure }\end{array}$ & 632,949 & 200,772 & 200,772 & 200,772 & 200,772 & 200,772 & 200,772 & 200,772 & 200,772 & 200,772 & 200,772 & 200,772 & 200,772 & 200,772 & 200,772 \\
\hline $\begin{array}{l}\text { NET CASH } \\
\text { FLOW }\end{array}$ & $-632,949$ & 265,310 & 265,310 & 265,310 & 265,310 & 265,310 & 265,310 & 265,310 & 265,310 & 265,310 & 265,310 & 265,310 & 265,310 & 265,310 & 265,310 \\
\hline
\end{tabular}


Table 5.21. Cash flow (USD) assessment for ozonation alternative

\begin{tabular}{|c|c|c|c|c|c|c|c|c|c|c|c|c|c|c|c|}
\hline "YEARS & 2008 & 2009 & 2010 & 2011 & 2012 & 2013 & 2014 & 2015 & 2016 & 2017 & 2018 & 2019 & 2020 & 2021 & 2022 \\
\hline \multicolumn{16}{|l|}{ Revenues } \\
\hline $\begin{array}{l}\text { Water } \\
\text { Recovery }\end{array}$ & 0 & 0 & 0 & 0 & 0 & 0 & 0 & 0 & 0 & 0 & 0 & 0 & 0 & 0 & 0 \\
\hline $\begin{array}{l}\text { Reduction in } \\
\text { WW }\end{array}$ & 0 & 0 & 0 & 0 & 0 & 0 & 0 & 0 & 0 & 0 & 0 & 0 & 0 & 0 & 0 \\
\hline $\begin{array}{l}\text { TOTAL } \\
\text { Revenue }\end{array}$ & 0 & 0 & 0 & 0 & 0 & 0 & 0 & 0 & 0 & 0 & 0 & 0 & 0 & 0 & 0 \\
\hline \multicolumn{16}{|l|}{ Expenditures } \\
\hline \multicolumn{16}{|l|}{ Investment } \\
\hline Cost & $3,118,746$ & 0 & 0 & 0 & 0 & 0 & 0 & 0 & 0 & 0 & 0 & 0 & 0 & 0 & 0 \\
\hline \multicolumn{16}{|l|}{ Operating } \\
\hline Cost & 0 & 978,048 & 978,048 & 978,048 & 978,048 & 978,048 & 978,048 & 978,048 & 978,048 & 978,048 & 978,048 & 978,048 & 978,048 & 978,048 & 978,048 \\
\hline \multicolumn{16}{|l|}{ TOTAL } \\
\hline Expenditure & $3,118,746$ & 978,048 & 978,048 & 978,048 & 978,048 & 978,048 & 978,048 & 978,048 & 978,048 & 978,048 & 978,048 & 978,048 & 978,048 & 978,048 & 978,048 \\
\hline NET CASH & - & - & - & - & - & - & - & - & - & - & - & - & - & - & - \\
\hline FLOW & $3,118,746$ & 978,048 & 978,048 & 978,048 & 978,048 & 978,048 & 978,048 & 978,048 & 978,048 & 978,048 & 978,048 & 978,048 & 978,048 & 978,048 & 978,048 \\
\hline
\end{tabular}




\subsubsection{Net Present Value (NPV)}

According to the abovementioned cash flow analysis, net present values (NPV) of the alternatives considered were calculated. Simply, NPV is the sum of the present worths of net benefits by discounting the stream of benefits and costs back to the beginning of the year. It can be calculated from the following formula:

$$
N P V=\sum_{i=0}^{n} \frac{\Delta-C_{i}}{(-t+r)^{2}}
$$

where;

$B_{t} \quad:$ The benefits in the " $t$ " th year,

$\mathrm{C}_{\mathrm{t}} \quad$ : The cost in the " $\mathrm{t}$ " th year,

r : The discount rate,

$\mathrm{n} \quad$ : The economic life of the alternative.

Here, discount rate is the rate at which future cash flows are discounted to convert them to present values [51]. While calculating the NPV for the alternatives, discount rate was assumed to be $10 \%$. In addition, as it was stated in the cash flow calculations, economic life of these alternatives under consideration was taken as 15 years. By using the abovementioned formula, NPV for each of the alternative were evaluated as illustrated in Table 5.22. 
Table 5.22. NPV values of the water recovery alternatives

\begin{tabular}{cc}
\hline \hline Alternative Options & NPV \\
& (USD) \\
\hline \hline MF + NF & $1,201,370$ \\
\hline Ozonation & $-9,385,198$ \\
\hline \hline
\end{tabular}

\subsubsection{Internal Rate of Return}

The rate of return on the investment that equates the present value of benefits and costs can be defined as the internal rate of return (IRR). In other words, it is the interest rate at which the benefits are equivalent to the costs [49]. This concept can be presented with the following relationship:

$\sum_{t=0}^{n} \frac{B_{t}}{(1+r)^{t}}=\sum_{t=0}^{n} \frac{C_{t}}{(1+r)^{2}}$

where;

$\mathrm{B}_{\mathrm{t}} \quad$ : The benefits in the " $\mathrm{t}$ " th year,

$\mathrm{C}_{\mathrm{t}} \quad$ : The cost in the " $\mathrm{t}$ " th year,

r : The discount rate,

n : The economic life of the alternative.

If the project has high IRR value, then it can be concluded that the project would be financially applicable. However, if the IRR value is lower than the discount rate, the 
application of that alternative would be unattractive. IRR values were calculated for both of the alternative options under consideration. The values are given in Table 5.23 .

Table 5.23. IRR values of the water recovery alternatives

\begin{tabular}{cc}
\hline \hline Alternative Options & $\begin{array}{c}\text { IRR } \\
(\%)\end{array}$ \\
\hline \hline MF + NF & 42 \\
\hline Ozonation & NA \\
\hline \hline
\end{tabular}

\subsubsection{Annual Cost Calculations}

The Reference Document states that cost data of the alternative options should be calculated and presented as annual costs. Annual cost can be accomplished by converting all the cash flows accruing over the economic lifetime of the alternative to an equivalent annual cost. In other words, it is the multiplication of the present value of the total cost stream, which consists of investment expenditure plus net operating cost, with capital recovery factor [2]. Annual cost can be calculated by using the formula mentioned below:

Annual cost $=\left[\sum_{i=0}^{m} \frac{\epsilon_{t}+Q G_{c}}{\frac{1}{1+r} \gamma^{2}}\right]\left[\frac{m \times(1+r)^{n}}{(1+r)^{n}-1}\right]$

where; 
$\mathrm{C}_{\mathrm{t}}$ : The investment expenditure in the " $\mathrm{t}$ " th year,

$\mathrm{B}_{\mathrm{t}} \quad$ : The operating cost in the " $\mathrm{t}$ " th year,

r : The discount rate,

$\mathrm{n} \quad$ : The economic life of the alternative.

Here, second multiplier of the given formula is called as the capital recovery factor. It converts a present value into a stream of equal annual payments over a specified time, at a specified discount rate. According to the given equation, the annual costs for the two water recovery alternatives were calculated and presented in Table 5.24.

Table 5.24. Annual costs of the water recovery alternatives

\begin{tabular}{ccc}
\hline $\begin{array}{c}\text { Alternative } \\
\text { Options }\end{array}$ & $\begin{array}{c}\text { Capital Recovery Factor } \\
(\%)\end{array}$ & $\begin{array}{c}\text { Annual Costs } \\
\text { (USD) }\end{array}$ \\
\hline \hline MF + NF & 13 & 277,621 \\
\hline Ozonation & 13 & $1,357,298$ \\
\hline \hline
\end{tabular}

\subsubsection{Evaluation of the Water Recovery Alternatives}

\subsubsection{Cost Effectiveness and Benefit Analysis}

In accordance with Chapter 3, it is essential to verify the cost effectiveness of the alternatives considered. In this part of the thesis, in order to determine the cost effectiveness of the alternatives, the annual costs of them were divided into annual reduction of pollutants. The calculated cost effectiveness values are given in Table 5.25 . 
Table 5.25. Cost effectiveness of the water recovery alternatives

\begin{tabular}{cccc}
\hline \hline $\begin{array}{c}\text { Alternative } \\
\text { Options }\end{array}$ & $\begin{array}{c}\text { Annual Costs } \\
\text { (USD) }\end{array}$ & $\begin{array}{c}\text { Annual Reduction } \\
\text { of COD } \\
\text { (kg/year) }\end{array}$ & $\begin{array}{c}\text { Cost Effectiveness } \\
\text { (USD/kg COD } \\
\text { reduced) }\end{array}$ \\
\hline \hline MF + NF & 277,621 & 632,472 & 0.45 \\
\hline Ozonation & $1,357,298$ & 399,456 & 3.77 \\
\hline \hline
\end{tabular}

It can be seen from the table that to reduce each kilogram of COD, more money should be paid in the ozonation process. However, cost of the membrane filtration process is one eighth of that of ozonation process. Both of the alternatives achieved high amounts of COD reduction. On the other hand, they cause environmental impacts due to emissions generated from the energy usages. Therefore, in order to compare the alternatives, these environmental damages should be evaluated. However, these damages could not able to be evaluated since no data exist in the literature presenting the valuation of the environmental impacts. For that reason, it was assessed from the impacts and COD ratios that the lower the environmental impacts, the higher the COD reduction in the water recovery alternative. 


\subsection{Analysis of Wastewater Treatability Studies}

As it is represented previously, five different treatment patterns were applied for the wastewaters generated whole through the textile mill. In this part of the chapter, these treatment alternatives are discussed with respect to their environmental and economical considerations. In these calculations, the mixed wastewater flowrate was assumed as 3,250 $\mathrm{m}^{3} /$ day (Figure 4.1).

\subsubsection{Environmental Effect Analysis}

\subsubsection{Identification of the Alternatives}

Similar to the water recovery alternatives, wastewater treatability alternatives were also assessed in terms of their cross-media effects initially. It is important to give the definitions of the alternatives according to their technical considerations concluded from the lab-scale experiments. These issues are given in Table 5.26 with the assumptions made. 
Table 5.26. Identification of the wastewater treatability alternatives

\begin{tabular}{cccccc}
\hline \hline $\begin{array}{c}\text { Alternative } \\
\text { Options }\end{array}$ & $\begin{array}{c}\text { Influent } \\
\text { COD } \\
(\mathbf{m g} / \mathbf{L})\end{array}$ & $\begin{array}{c}\text { Influent } \\
\text { Color } \\
(\mathbf{P t - C o})\end{array}$ & $\begin{array}{c}\text { COD } \\
\text { Removal } \\
\mathbf{( \% )}\end{array}$ & $\begin{array}{c}\text { Color } \\
\text { Removal } \\
\mathbf{( \% )}\end{array}$ & $\begin{array}{c}\text { Water } \\
\text { Recovery } \\
\mathbf{( \% )}\end{array}$ \\
\hline \hline AS + MF + NF & 1,800 & 3,800 & 90 & 100 & 70 \\
\hline $\begin{array}{c}\text { Membrane } \\
\text { Bioreactor }\end{array}$ & 1,800 & 3,800 & 97 & 98 & 70 \\
\hline Ozonation + AS & 1,800 & 3,800 & 47 & 86 & - \\
\hline Peroxone + AS & 1,800 & 3,800 & 47 & 86 & - \\
\hline AS + Ozonation & 1,800 & 3,800 & 50 & 98 & - \\
\hline \hline
\end{tabular}

\subsubsection{Inventory of Consumptions and Emissions}

Each treatment alternative was evaluated in terms of their energy consumption in order to calculate the inventory of consumptions and emissions. Table 5.27 shows the specific consumption values of the alternatives taken under consideration. 
Table 5.27. Specific energy consumptions of treatment alternatives [45]

\begin{tabular}{cc}
\hline \hline Alternatives & $\begin{array}{c}\text { Specific energy } \\
\text { consumption } \\
\left(\mathbf{k W h} / \mathbf{m}^{\mathbf{3}}\right)\end{array}$ \\
\hline \hline Activated Sludge + MF + NF & 6.20 \\
\hline Membrane Bioreactor & 2.50 \\
\hline Ozonation + Activated Sludge & 45.88 \\
\hline Peroxone + Activated Sludge & 52.98 \\
\hline Activated Sludge + Ozonation & 14.50 \\
\hline \hline
\end{tabular}

By using the abovementioned specific energy consumption values for each of the alternative, electricity used in a day through the options were calculated and illustrated in Table 5.28.

Table 5.28. Electricity usage of treatment alternatives

\begin{tabular}{cc}
\hline Alternatives & $\begin{array}{c}\text { Electricity } \\
(\mathbf{k W h} / \text { day })\end{array}$ \\
\hline \hline Activated Sludge + MF + NF & 20,150 \\
\hline Membrane Bioreactor & 8,125 \\
\hline Ozonation + Activated Sludge & 149,094 \\
\hline Peroxone + Activated Sludge & 188,419 \\
\hline Activated Sludge + Ozonation & 47,125 \\
\hline \hline
\end{tabular}


In the water recovery studies, the average fuel use and emissions released to create $1 \mathrm{GJ}$ of electricity are given in Table 5.5. According to this table, $\mathrm{SO}_{2}, \mathrm{CO}_{2}$, and $\mathrm{NO}_{2}$ emissions were determined. In fact, the mass of pollutant released to the air from the application of these alternatives was calculated. Table 5.29 shows the emission values of the alternatives options, whereas Table 5.30 indicates the mass of pollutant released to air.

Table 5.29. Calculated emission values released from the treatment alternative options

\begin{tabular}{|c|c|c|c|}
\hline Alternative options & Type & Unit & Value \\
\hline \multirow{3}{*}{ Activated Sludge $+\mathrm{MF}+\mathrm{NF}$} & $\overline{\mathrm{SO}_{2}}$ & $\overline{\mathrm{kg} / \text { day }}$ & 7.25 \\
\hline & $\mathrm{CO}_{2}$ & $\mathrm{~kg} /$ day & $8,484.18$ \\
\hline & $\mathrm{NO}_{2}$ & $\mathrm{~kg} /$ day & 11.61 \\
\hline \multirow{3}{*}{ Membrane Bioreactor } & $\mathrm{SO}_{2}$ & $\mathrm{~kg} /$ day & 2.93 \\
\hline & $\mathrm{CO}_{2}$ & $\mathrm{~kg} /$ day & $3,422.25$ \\
\hline & $\mathrm{NO}_{2}$ & $\mathrm{~kg} /$ day & 4.61 \\
\hline \multirow{3}{*}{ Ozonation + Activated Sludge } & $\mathrm{SO}_{2}$ & kg/day & 53.67 \\
\hline & $\mathrm{CO}_{2}$ & $\mathrm{~kg} /$ day & $62,798.30$ \\
\hline & $\mathrm{NO}_{2}$ & $\mathrm{~kg} /$ day & 85,88 \\
\hline \multirow{3}{*}{ Peroxone + Activated Sludge } & $\mathrm{SO}_{2}$ & kg/day & 67,83 \\
\hline & $\mathrm{CO}_{2}$ & $\mathrm{~kg} /$ day & $79,362.98$ \\
\hline & $\mathrm{NO}_{2}$ & $\mathrm{~kg} /$ day & 108.53 \\
\hline \multirow{3}{*}{ Activated Sludge + Ozonation } & $\overline{\mathrm{SO}_{2}}$ & "kg/day & 16.97 \\
\hline & $\mathrm{CO}_{2}$ & $\mathrm{~kg} /$ day & $19,849.05$ \\
\hline & $\mathrm{NO}_{2}$ & $\mathrm{~kg} /$ day & 27.14 \\
\hline
\end{tabular}


Table 5.30. Mass of pollutants released to air due to treatment alternatives

\begin{tabular}{cc}
\hline \hline Alternative Options & $\begin{array}{c}\text { Mass of pollutant } \\
\text { (kg/day) }\end{array}$ \\
\hline \hline Activated Sludge + MF + NF & $8,484.18$ \\
\hline Membrane Bioreactor & $3,422.25$ \\
\hline Ozonation + Activated Sludge & $62,798.30$ \\
\hline Peroxone + Activated Sludge & $79,362.98$ \\
\hline Activated Sludge + Ozonation & $19,849.05$ \\
\hline \hline
\end{tabular}

It is mentioned in Table 5.26 that wastewater recovery would be achieved only by the implementation of the first and the second alternatives which are activated sludge followed by MF and NF, and membrane bioreactor, respectively. For that reason, mass of pollutant released to aquatic environment assumed as the mass of the rejected stream generated from these alternatives. According to their COD removal ratios (Table 5.26), mass of COD discharged to the environment was assumed to be the mass of pollutant released to aquatic environment. On the other hand, the reduced mass of COD, which turns into sludge, was assumed to be the hazardous waste. Both the mass of pollutant released to aquatic environment and hazardous waste amounts are presented in Table 5.31 and Table 5.32, respectively with the COD removal ratios of each alternative option. In the hazardous waste calculations, yield coefficients were assumed as 0.5 and 0.05 for activated sludge processes and MBR process respectively. 
Table 5.31. Mass of pollutants released to aquatic environment of treatability alternatives

\begin{tabular}{cc}
\hline \hline Alternative Options & $\begin{array}{c}\text { Mass of pollutants } \\
\text { (kg/day) }\end{array}$ \\
\hline \hline Activated Sludge + MF + NF & 585 \\
\hline Membrane Bioreactor & 153 \\
\hline Ozonation + Activated Sludge & 3,101 \\
\hline Peroxone + Activated Sludge & 3,101 \\
\hline Activated Sludge + Ozonation & 2,925 \\
\hline \hline
\end{tabular}

Table 5.32. Hazardous waste amounts of the treatability alternatives

\begin{tabular}{cc}
\hline \hline Alternative Options & $\begin{array}{c}\text { Hazardous Waste } \\
\text { (kg/day) }\end{array}$ \\
\hline \hline Activated Sludge + MF + NF & 2,633 \\
\hline Membrane Bioreactor & 285 \\
\hline Ozonation + Activated Sludge & 1,375 \\
\hline Peroxone + Activated Sludge & 1,375 \\
\hline Activated Sludge + Ozonation & 1,463 \\
\hline \hline
\end{tabular}

\subsubsection{Cross-Media Effects of the Alternatives}

Six environmental themes were also assessed for the wastewater treatability alternatives similar to the water recovery alternatives. However, one additional 
concern was taken into account. In order to evaluate the alternatives in terms of color removal efficiency, a new concept which is aesthetical pollution was adjusted.

It is again the same for wastewater treatability alternatives that they have no direct cause on the environmental themes mentioned previously, they have indirect effects due to energy consumption which results in releasing of emissions.

Human toxicity, global warming potential, acidification, eutrophication, ozone depletion, photochemical ozone creation potential, and aesthetical pollution calculations were performed and the overall results of these calculations are given as a summary in Table 5.33. These values were calculated according to the emission values of $\mathrm{SO}_{2}, \mathrm{CO}_{2}$, and $\mathrm{NO}_{2}$ indicated in Table 5.29, and the factors presented in the Reference Document. 
Table 5.33. Cross-media effects of the wastewater treatability alternatives

\begin{tabular}{|c|c|c|c|c|c|c|c|}
\hline $\begin{array}{c}\text { Alternative } \\
\text { Options }\end{array}$ & $\begin{array}{c}\text { Human } \\
\text { Toxicity } \\
\text { (kg lead } \\
\text { equivalents) }\end{array}$ & $\begin{array}{c}\text { Global } \\
\text { warming } \\
\text { (kg CO} \mathrm{C}_{2} \\
\text { equivalents) }\end{array}$ & $\begin{array}{l}\text { Acidification } \\
\qquad(\mathrm{kg} \mathrm{SO} \\
\text { equivalents })\end{array}$ & $\begin{array}{l}\text { Eutrophication } \\
\qquad \mathrm{kg} \mathrm{PO}_{4}^{-3} \\
\text { equivalents) }\end{array}$ & $\begin{array}{c}\text { Ozone } \\
\text { Depletion } \\
\text { (kg CFC } \\
\text { equivalents) }\end{array}$ & $\begin{array}{c}\text { Photochemical } \\
\text { ozone creation } \\
\text { (kg ethylene } \\
\text { equivalents) }\end{array}$ & $\begin{array}{c}\text { Aesthetical } \\
\text { Pollution } \\
\text { (Pt-Co) }\end{array}$ \\
\hline $\begin{array}{c}\text { Activated Sludge } \\
+\mathrm{MF}+\mathrm{NF}\end{array}$ & 0.68 & 8,487 & 13.06 & - & - & 44.45 & 0.00 \\
\hline $\begin{array}{l}\text { Membrane } \\
\text { Bioreactor }\end{array}$ & 0.27 & 3,422 & 5.27 & - & - & 17.92 & 82.30 \\
\hline $\begin{array}{c}\text { Ozonation }+ \\
\text { Activated Sludge }\end{array}$ & 5.03 & 62,798 & 96.61 & - & - & 328.91 & 532.00 \\
\hline $\begin{array}{c}\text { Peroxone }+ \\
\text { Activated Sludge }\end{array}$ & 6.36 & 79,362 & 122.10 & - & - & 415.67 & 532.00 \\
\hline $\begin{array}{l}\text { Activated Sludge } \\
\text { + Ozonation }\end{array}$ & 1.59 & 19,849 & 30.54 & - & - & 103.96 & 76.00 \\
\hline
\end{tabular}




\subsubsection{Financial Analysis}

According to the costing methodology stated in the Reference Document, treatability alternatives were evaluated economically. In this part of the thesis, investment costs and operating and maintenance costs of each treatment alternative are introduced. In addition to these cost components, net present values, internal rate of returns and annual costs are determined.

\subsubsection{Investment Costs}

\section{Part I. Activated Sludge Followed by Membrane Filtration Processes}

The first alternative consists of membrane filtration processes which are MF and NF after the activated sludge process. As it was stated, the textile mill taken under consideration has an existing wastewater treatment plant consisting of an activated sludge system. Therefore, there is no need for an investment for such a system where it takes place in some of the treatment pattern in this study. However, this alternative of treatability has the investment cost consisting of only membrane filtration costs. The same calculation pattern with the calculations applied in the membrane filtration processes implemented to dyeing wastewaters was used. The only differences are the flowrate and flux values applied. In wastewater treatability studies, the flux value that experimented was $34 \mathrm{~L} / \mathrm{m}^{2}-\mathrm{hr}$. For estimating the investment costs, equations given in Table 2.8 were used similarly. The investment need for such system is given in Table 5.34. 
Table 5.34. Investment costs for MF and NF process for treatability alternatives

\begin{tabular}{ccc}
\hline Membrane Filtration & Components & $\begin{array}{c}\text { Investment } \\
\text { Costs }\end{array}$ \\
\hline \hline MF & Mechanical investment & 487,500 \\
\cline { 2 - 3 } & TOTAL (USD) & $\mathbf{4 8 7 , 5 0 0}$ \\
\hline \multirow{2}{*}{ NF } & Civil investments & 250,101 \\
& Mechanical investments & 331,726 \\
\cline { 2 - 3 } & Membrane investments & 131,821 \\
\cline { 2 - 3 } & Additional investments & 142,730 \\
\cline { 2 - 3 } & TOTAL (EUR) & $\mathbf{8 5 6 , 3 7 8}$ \\
\cline { 2 - 3 } MF + NF & TOTAL (USD) & $\mathbf{1 , 3 4 4 , 5 1 3}$ \\
\hline \hline
\end{tabular}

It can be calculated from the overall investment cost of the application of MF and NF after activated sludge process that the unit cost of the treatment pattern would be 564 USD per $\mathrm{m}^{3}$ of textile wastewater treated where unit investment cost of MF was 150 USD per $\mathrm{m}^{3}$ and that of NF was 414 USD per $\mathrm{m}^{3}$.

\section{Part II. Membrane Bioreactor Process}

The second alternative is the membrane bioreactor process. While estimating the investment cost of the system, three items were taken into account. These are civil investments, membrane investments, and non-membrane investments. It was assumed that civil investment needs would be equal to the civil investment needs calculated for the NF alternative, since the flowrate and COD values were the same 
for each of the systems. In fact, it was assumed as 250,101 EUR that is equal to 392,658 USD with an exchange rate of 1.57 EUR per USD.

In order to evaluate the membrane costs, firstly, the required membrane area for the system was determined by using $15 \mathrm{~L} / \mathrm{m}^{2}-\mathrm{hr}$ of flux designated experimentally in labscale studies. As a result, the required membrane area was calculated as $9,028 \mathrm{~m}^{2}$. The average unit cost of membrane was found from the literature. It was assumed as 125 USD per $\mathrm{m}^{2}$ of membrane area. Consequently, membrane investment was calculated as 1,128,472 USD. In this study, this membrane investment was assumed to be $30 \%$ of the total mechanical expenditure. For this purpose, Table 5.35 shows the investment items and the total investment need of the membrane bioreactor alternative.

Table 5.35. Investment costs for MBR process

\begin{tabular}{cc}
\hline \hline Components & $\begin{array}{c}\text { Investment Costs } \\
\text { (USD) }\end{array}$ \\
\hline \hline Civil investments & 392,658 \\
\hline Membrane investments & $1,128,472$ \\
\hline Non-membrane investments & $2,240,444$ \\
\hline \hline TOTAL & $\mathbf{3 , 7 6 1 , 5 7 4}$ \\
\hline \hline
\end{tabular}

The unit investment cost can be calculated by dividing the total investment cost value into flowrate. In this thesis, this value was determined as 1,157 USD per each $\mathrm{m}^{3}$ of wastewater treated. 


\section{Part III. Ozonation Process before Activated Sludge}

As it was calculated in the water recovery studies, investment need for the ozonation system was determined from the equation shown in Equation (4). In order to use that equation, hourly ozone requirement should be calculated. The experimental studies showed that 2.33 gram of ozone was needed for the reduction of each gram of COD. COD reduction was performed as $47 \%$ which corresponded to 114,563 grams of COD reduced with respect to $1,800 \mathrm{mg} / \mathrm{L}$ of initial COD.

By using the abovementioned equation, the investment cost of the equipment needed for ozonation process was calculated as 3,705,431 EUR. In addition to this equipment cost, civil investments were again assumed as the same as the civil investment costs calculated for membrane filtration alternatives. Therefore, the total investment need for this alternative was determined as 3,955,531 EUR where this value equaled to 6,210,184 USD due to the exchange rate assumed as 1.57 EUR per USD.

\section{Part IV. Peroxone Process before Activated Sludge}

As it is mentioned before, in this thesis, one of the wastewater treatability alternative evaluated in terms of economic considerations is the peroxone process applied before the existing activated sludge system in the selected textile mill. The only difference between this alternative and third alternative which is ozonation before the activated sludge is the hydrogen peroxide usage in the process. The only financial effect due to hydrogen peroxide would be in the operating costs. Therefore, it was assumed in this thesis that the investment cost of this fourth alternative would be the same with the ozonation application after activated sludge system which was calculated as $6,210,184$ USD. Moreover, the investment need due to the pumping requirement of hydrogen peroxide was ignored. 


\section{Part V. Ozonation process after Activated Sludge}

The last alternative considered is the post-ozonation application. In this alternative, effluents of the activated sludge system had different wastewater characterization. The wastewater characterization was given before as $800 \mathrm{mg} / \mathrm{L}$ of COD, and 2,100 Pt-Co of color for the wastewater entering to the ozonation process. Since COD concentration was determined less than the initial COD concentrations mentioned for the other ozonation processes, the alternative required less ozone for treating wastewater. For this purpose, in the post-ozonation experiments, ozone requirement of the process was determined as 0.44 grams per each gram of COD to be treated. It was also conducted from the experiments that application of ozonation resulted with $50 \%$ of COD removal.

According to these values stated above, ozone requirement was calculated as 23,833 grams per hour. Moreover, equipment cost was computed by using Equation (4) and found to be 840,833 EUR. As a result, total investment cost was estimated at $1,711,541$ USD.

Consequently, investment costs of the wastewater treatability alternatives were mentioned above. According to these cost figures, it seems that membrane bioreactor process has the lowest investment cost, on the other hand ozonation is the highest one in terms of investment costs. All these investment costs were summarized in Table 5.36. 
Table 5.36. Investment costs of treatability alternatives

\begin{tabular}{ccc}
\hline \hline Alternative Options & $\begin{array}{c}\text { Investment } \\
\text { Costs } \\
\text { (USD) }\end{array}$ & $\begin{array}{c}\text { Unit } \\
\text { Investment } \\
\text { Costs } \\
\left(\mathbf{U S D} / \mathbf{m}^{\mathbf{3}}\right)\end{array}$ \\
\hline \hline AS + MF + NF & $1,832,013$ & 564 \\
\hline Membrane Bioreactor & $3,761,574$ & 1,157 \\
\hline Ozonation + AS & $6,210,184$ & 1,911 \\
\hline Peroxone + AS & $6,210,184$ & 1,911 \\
\hline AS + Ozonation & $1,711,541$ & 527 \\
\hline \hline
\end{tabular}

\subsubsection{Operating Costs}

In this part of the thesis, in addition to investment cost analysis, operating costs of the considered treatability alternatives were also estimated.

\section{Part I. Activated Sludge Followed by Membrane Filtration Processes}

Since the existing wastewater treatment is still in operation, the textile mill has an operating cost for this system. According to the information gathered from the selected textile mill, operating costs for the existing system are illustrated in Table 5.37. In this table, monthly expenditures of the textile mill taken under consideration were illustrated. In addition to this table, Table 5.38 shows the unit operating cost of the system in USD. 
Table 5.37. Operating costs for existing activated sludge system of the textile mill

\begin{tabular}{cc}
\hline Components & $\begin{array}{c}\text { Annual } \\
\text { Operating Costs } \\
\text { (YTL) }\end{array}$ \\
\hline \hline Energy & 7,140 \\
\hline Depreciation & 9,933 \\
\hline Labour & 2,500 \\
\hline Wastewater taxes & 20,756 \\
\hline Maintenance & 40,000 \\
\hline Chemical & 25,588 \\
\hline \hline TOTAL & $\mathbf{1 0 5 , 9 1 7}$ \\
\hline \hline
\end{tabular}

Table 5.38. Unit operating costs for existing activated sludge system of the textile mill

\begin{tabular}{cc}
\hline \hline Components & $\begin{array}{c}\text { Operating Costs } \\
\left(\mathbf{U S D} / \mathbf{m}^{\mathbf{3}}\right)\end{array}$ \\
\hline \hline Energy & 0.06 \\
\hline Depreciation & 0.08 \\
\hline Labour & 0.02 \\
\hline Wastewater taxes & 0.17 \\
\hline Maintenance & 0.33 \\
\hline Chemical & 0.21 \\
\hline \hline TOTAL & $\mathbf{0 . 8 7}$ \\
\hline \hline
\end{tabular}


In the experimental study, membrane filtration processes, namely MF and NF, were applied to the biologically pre-treated wastewater. Therefore, for this alternative, membrane filtration operating costs were also determined in addition to the activated sludge operating costs. Similarly, the same procedure that used in the water recovery alternatives was applied. While determining the energy cost, unit price of electricity was again assumed as 0.072 YTL per $\mathrm{kWh}$. The results of the calculations for the operating costs are given in Table 5.39.

Table 5.39. Operating costs for MF + NF application

\begin{tabular}{cccc}
\hline \hline Components & $\begin{array}{c}\text { MF Operating } \\
\text { Costs } \\
\left(\mathbf{U S D} / \mathbf{m}^{\mathbf{3}}\right)\end{array}$ & $\begin{array}{c}\text { NF Operating } \\
\text { Costs } \\
\left(\mathbf{U S D} / \mathbf{m}^{\mathbf{3}}\right)\end{array}$ & $\begin{array}{c}\text { TOTAL } \\
\left(\mathbf{U S D} / \mathbf{m}^{\mathbf{3}}\right)\end{array}$ \\
\hline \hline Energy & 0.02 & 0.31 & 0.34 \\
\hline Depreciation & 0.04 & 0.08 & 0.12 \\
\hline Maintenance & 0.01 & 0.02 & 0.03 \\
\hline Quality control & 0.01 & 0.02 & 0.03 \\
\hline $\begin{array}{c}\text { Operating of } \\
\text { installation }\end{array}$ & 0.01 & 0.02 & 0.03 \\
\hline Chemical & 0.04 & 0.04 & 0.08 \\
\hline \hline TOTAL & $\mathbf{0 . 1 3}$ & $\mathbf{0 . 4 9}$ & $\mathbf{0 . 6 2}$ \\
\hline
\end{tabular}

According to the abovementioned operating costs, the overall operating cost for the alternative consisting of membrane filtration application after the activated sludge process for the textile wastewater generated in the selected mill for wastewater 
treatability purposes was evaluated as 1.49 USD per each $\mathrm{m}^{3}$ of wastewater recovered.

\section{Part II. Membrane Bioreactor Process}

While estimating the operating cost of the membrane bioreactor, energy, depreciation of assets, membrane replacement, maintenance, quality control, operation of installation, and chemical costs were taken into account. Energy cost was determined from the specific energy consumption where each $\mathrm{kWh}$ of electricity was evaluated as 0.072 YTL with respect to the data gathered from the selected mill. In depreciation of assets, equipment year was assumed as 15 years whereas 5 years of membrane depreciation was used. Moreover, maintenance, quality control, and operation of the installation were calculated as $2 \%$ of the total investment cost of membrane bioreactor. On the other hand, 0.04 EUR per treated wastewater was assumed to be the chemical cost. Table 5.40 shows the operating cost of the membrane bioreactor in more detail. 
Table 5.40. Operating costs for MBR application

\begin{tabular}{cc}
\hline Components & $\begin{array}{c}\text { Operating Costs } \\
\left(\mathbf{U S D} / \mathbf{m}^{\mathbf{3}}\right)\end{array}$ \\
\hline Energy & 0.09 \\
\hline Depreciation of assets & 0.13 \\
\hline Membrane replacement & 0.19 \\
\hline Maintenance & 0.06 \\
\hline Quality control & 0.06 \\
\hline \hline Operating of installation & 0.06 \\
\hline \hline Chemical & 0.04 \\
\hline \hline
\end{tabular}

\section{Part III. Ozonation Process before Activated Sludge}

The operating cost calculation for this alternative was executed with the same procedure as it was applied for ozonation process in dyeing wastewaters. All the operating items were illustrated below in Table 5.41. Moreover, working sheet for ozonation cost assessments is given in Appendix C (Figure C.4). 
Table 5.41. Operating costs for ozonation application before activated sludge system

\begin{tabular}{cc}
\hline \hline Components & $\begin{array}{c}\text { Operating Costs } \\
\left(\mathbf{U S D} / \mathbf{m}^{\mathbf{3}}\right)\end{array}$ \\
\hline \hline Energy & 2.64 \\
\hline Depreciation & 0.35 \\
\hline Maintenance & 0.11 \\
\hline Quality control & 0.11 \\
\hline \hline Operating of installation & 0.11 \\
\hline TOTAL & $\mathbf{3 . 3 1}$ \\
\hline
\end{tabular}

It can be seen that due to high specific energy consumption, energy cost of this alternative was high compared to the other components. Moreover, since ozonation is an expensive treatment alternative in terms of investment cost, depreciation cost was also found to be high. The total operating cost for this alternative would be the summation of the operating cost calculated for ozonation and that for existing activated sludge system. This was calculated as 4.17 USD per $\mathrm{m}^{3}$.

\section{Part IV. Peroxone Process before Activated Sludge}

In this alternative, in addition to ozone dosage hydrogen peroxide $\left(\mathrm{H}_{2} \mathrm{O}_{2}\right)$ was also added to the system. As it was considered, addition of $\mathrm{H}_{2} \mathrm{O}_{2}$ would cause an increase in the operating costs. From the literature, the average cost of $\mathrm{H}_{2} \mathrm{O}_{2}$ was found as 0.50 USD per kilogram of $\mathrm{H}_{2} \mathrm{O}_{2}$. Furthermore, the experiments performed for this alternative showed that for such kind of treatment alternative, approximately 1.5 kilograms of $\mathrm{H}_{2} \mathrm{O}_{2}$ was needed in order to treat each $\mathrm{m}^{3}$ of wastewater. As a result, operating cost caused by $\mathrm{H}_{2} \mathrm{O}_{2}$ would be 0.75 USD per $\mathrm{m}^{3}$ where it was stated as chemical cost. 
Considering the energy requirement, it was calculated in the cross-media effect analysis that the specific energy consumption of the peroxone alternative was 57.98 $\mathrm{kWh}$ per $\mathrm{m}^{3}$ of wastewater. For that reason, the energy cost was estimated at 3.34 USD. The rest of the operating cost items are given in Table 5.42.

Table 5.42. Operating costs for peroxone treatment before activated sludge system

\begin{tabular}{cc}
\hline \hline Components & $\begin{array}{c}\text { Operating Costs } \\
\left(\mathbf{U S D} / \mathbf{m}^{\mathbf{3}}\right)\end{array}$ \\
\hline \hline Energy & 3.34 \\
\hline Depreciation & 0.35 \\
\hline Maintenance & 0.11 \\
\hline Quality control & 0.11 \\
\hline Operating of installation & 0.11 \\
\hline Chemical & 0.75 \\
\hline TOTAL & $\mathbf{4 . 7 5}$ \\
\hline \hline
\end{tabular}

As a result of this calculations, the total operating cost of this peroxone before activated sludge alternative would be 5.62 USD per $\mathrm{m}^{3}$ where 4.75 USD of this was due to peroxone application, the rest 0.87 USD was due to the operation of existing activated sludge.

\section{Part V. Ozonation Process after Activated Sludge}

Ozonation was applied both before and after the activated sludge process. The same calculation with pre-ozonation alternative was executed for this alternative in order 
to find out the operating cost. The specific energy requirement for this alternative option was evaluated as $14.50 \mathrm{kWh}$ per $\mathrm{m}^{3}$. Therefore, the energy cost was calculated as 0.84 USD per $\mathrm{m}^{3}$. For depreciation cost assessment, the equipment life was thought to be 15 years. Moreover, maintenance, operation of installation, and quality control costs were assumed as $2 \%$ of the investment costs as it was the same with the previous operating cost calculations of the other alternatives. Table 5.43 shows these operating cost items.

Table 5.43. Operating costs for ozonation application after activated sludge system

\begin{tabular}{cc}
\hline \hline Components & $\begin{array}{c}\text { Operating Costs } \\
\left(\mathbf{U S D} / \mathbf{m}^{\mathbf{3}}\right)\end{array}$ \\
\hline \hline Energy & 0.84 \\
\hline Depreciation & 0.09 \\
\hline Maintenance & 0.03 \\
\hline Quality control & 0.03 \\
\hline \hline Operating of installation & 0.03 \\
\hline TOTAL & $\mathbf{1 . 0 2}$ \\
\hline \hline
\end{tabular}

Activated sludge was applied before the ozonation. Therefore, the total operating cost was the summation of 0.87 USD and 1.02 USD which resulted as 1.89 USD per $\mathrm{m}^{3}$ of treated wastewater.

To sum up, Table 5.44 shows all the operating costs calculated for each of the treatability alternatives mentioned in this part of the thesis. 
Table 5.44. Operating costs of the wastewater treatability alternatives

\begin{tabular}{cc}
\hline Alternative Options & $\begin{array}{c}\text { Operating Costs } \\
\left(\mathbf{U S D} / \mathbf{m}^{\mathbf{3}}\right)\end{array}$ \\
\hline Activated Sludge + MF + NF & 1.49 \\
\hline Membrane Bioreactor & 0.64 \\
\hline Ozonation + Activated Sludge & 4.17 \\
\hline Peroxone + Activated Sludge & 5.62 \\
\hline Activated Sludge + Ozonation & 1.89 \\
\hline \hline
\end{tabular}

\subsubsection{Revenues and Avoided Costs}

Revenues and avoided costs were determined for the treatability alternatives. As it was mentioned, lab-scale experiments showed that wastewater recovery was achieved only from the first two alternatives which were membrane filtration processes after activated sludge system and membrane bioreactor process. In addition, this recovery was assumed to be $70 \%$ of the influent wastewater. Therefore, for each of the alternative, daily wastewater recovery can be calculated as $2,275 \mathrm{~m}^{3}$. Also, the same amount of wastewater was not discharged to the environment. The total avoided costs for these two alternatives were calculated as $1,328,600$ USD per year.

On the other hand, no avoided costs were assessed for the rest of three alternatives since wastewater recovery was not achieved by the application of them. The following tables show the cash flow analysis for each of the alternative considered. 
Table 5.45. Cash flow (USD) assessment for activated sludge and membrane filtration alternative

\begin{tabular}{|c|c|c|c|c|c|c|c|c|c|c|c|c|c|c|c|}
\hline $\begin{array}{l}\text { YEARS } \\
\end{array}$ & 2008 & 2009 & 2010 & 2011 & 2012 & 2013 & 2014 & 2015 & 2016 & 2017 & 2018 & 2019 & 2 & 2021 & 2022 \\
\hline \multicolumn{16}{|l|}{ Revenues } \\
\hline Water Recovery & 0 & 664,300 & 664,300 & 664,300 & 664,300 & 664,300 & 664,300 & 664,300 & 664,300 & 664,300 & 664,300 & 664,300 & 664,300 & 664,300 & 664,300 \\
\hline $\begin{array}{c}\text { Reduction in } \\
\text { WW }\end{array}$ & 0 & 664,300 & 664,300 & 664,300 & 664,300 & 664,300 & 664,300 & 664,300 & 664,300 & 664,300 & 664,300 & 664,300 & 664,300 & 664,300 & 664,300 \\
\hline $\begin{array}{l}\text { TOTAL } \\
\text { Revenue }\end{array}$ & 0 & $1,328,600$ & $1,328,600$ & $1,328,600$ & $1,328,600$ & $1,328,600$ & $1,328,600$ & $1,328,600$ & $1,328,600$ & $1,328,600$ & $1,328,600$ & $1,328,600$ & $1,328,600$ & $1,328,600$ & $1,328,600$ \\
\hline \multicolumn{16}{|l|}{ Expenditures } \\
\hline Investment Cost & $1,832,013$ & 0 & 0 & 0 & 0 & 0 & 0 & 0 & 0 & 0 & 0 & 0 & 0 & 0 & 0 \\
\hline Operating Cost & 0 & $1,526,755$ & $1,526,755$ & $1,526,755$ & $1,526,755$ & $1,526,755$ & $1,526,755$ & $1,526,755$ & $1,526,755$ & $1,526,755$ & $1,526,755$ & $1,526,755$ & $1,526,755$ & $1,526,755$ & $1,526,755$ \\
\hline $\begin{array}{c}\text { TOTAL } \\
\text { Expenditure }\end{array}$ & $1,832,013$ & $1,526,755$ & $1,526,755$ & $1,526,755$ & $1,526,755$ & $1,526,755$ & $1,526,755$ & $1,526,755$ & $1,526,755$ & $1,526,755$ & $1,526,755$ & $1,526,755$ & $1,526,755$ & $1,526,755$ & $1,526,755$ \\
\hline $\begin{array}{c}\text { NET CASH } \\
\text { FLOW }\end{array}$ & $-1,832,013$ & $-198,155$ & $-198,155$ & $-198,155$ & $-198,155$ & $-198,155$ & $-198,155$ & $-198,155$ & $-198,155$ & $-198,155$ & $-198,155$ & $-198,155$ & $-198,155$ & $-198,155$ & $-198,155$ \\
\hline
\end{tabular}


Table 5.46. Cash flow (USD) assessment for membrane bioreactor alternative

\begin{tabular}{ccccccccccccccccc}
\hline \hline YEARS & $\mathbf{2 0 0 8}$ & $\mathbf{2 0 0 9}$ & $\mathbf{2 0 1 0}$ & $\mathbf{2 0 1 1}$ & $\mathbf{2 0 1 2}$ & $\mathbf{2 0 1 3}$ & $\mathbf{2 0 1 4}$ & $\mathbf{2 0 1 5}$ & $\mathbf{2 0 1 6}$ & $\mathbf{2 0 1 7}$ & $\mathbf{2 0 1 8}$ & $\mathbf{2 0 1 9}$ & $\mathbf{2 0 2 0}$ & $\mathbf{2 0 2 1}$ & $\mathbf{2 0 2 2}$ \\
\hline \hline $\begin{array}{c}\text { Revenues } \\
\text { Water Recovery }\end{array}$ & 0 & 664,300 & 664,300 & 664,300 & 664,300 & 664,300 & 664,300 & 664,300 & 664,300 & 664,300 & 664,300 & 664,300 & 664,300 & 664,300 & 664,300 \\
\hline $\begin{array}{c}\text { Reduction in } \\
\text { WW }\end{array}$ & 0 & 664,300 & 664,300 & 664,300 & 664,300 & 664,300 & 664,300 & 664,300 & 664,300 & 664,300 & 664,300 & 664,300 & 664,300 & 664,300 & 664,300 \\
\hline $\begin{array}{c}\text { TOTAL } \\
\text { Revenue }\end{array}$ & 0 & $1,328,600$ & $1,328,600$ & $1,328,600$ & $1,328,600$ & $1,328,600$ & $1,328,600$ & $1,328,600$ & $1,328,600$ & $1,328,600$ & $1,328,600$ & $1,328,600$ & $1,328,600$ & $1,328,600$ & $1,328,600$ \\
\hline $\begin{array}{c}\text { Expenditures } \\
\text { Investment Cost }\end{array}$ & $3,761,574$ & 0 & 0 & 0 & 0 & 0 & 0 & 0 & 0 & 0 & 0 & 0 & 0 & 0 & 0 \\
\hline $\begin{array}{c}\text { Operating Cost } \\
\text { TOTAL }\end{array}$ & 0 & 381,196 & 381,196 & 381,196 & 381,196 & 381,196 & 381,196 & 381,196 & 381,196 & 381,196 & 381,196 & 381,196 & 381,196 & 381,196 & 381,196 \\
\hline $\begin{array}{c}\text { Expenditure } \\
3,761,574\end{array}$ & 381,196 & 381,196 & 381,196 & 381,196 & 381,196 & 381,196 & 381,196 & 381,196 & 381,196 & 381,196 & 381,196 & 381,196 & 381,196 & 381,196 \\
\hline $\begin{array}{c}\text { NET CASH } \\
\text { FLOW }\end{array}$ & $3,761,574$ & 947,404 & 947,404 & 947,404 & 947,404 & 947,404 & 947,404 & 947,404 & 947,404 & 947,404 & 947,404 & 947,404 & 947,404 & 947,404 & 947,404 \\
\hline \hline
\end{tabular}


Table 5.47. Cash flow (USD) assessment for activated sludge with pre-ozonation alternative

\begin{tabular}{|c|c|c|c|c|c|c|c|c|c|c|c|c|c|c|c|}
\hline $\begin{array}{l}\text { YEARS } \\
\end{array}$ & 2008 & 2009 & 2010 & 2011 & 2012 & 2013 & 2014 & 2015 & 2016 & 2017 & 2018 & 2019 & 22020 & 2021 & 2022 \\
\hline \multicolumn{16}{|l|}{ Revenues } \\
\hline Water Recovery & 0 & 0 & 0 & 0 & 0 & 0 & 0 & 0 & 0 & 0 & 0 & 0 & 0 & 0 & 0 \\
\hline $\begin{array}{c}\text { Reduction in } \\
\text { WW }\end{array}$ & 0 & 0 & 0 & 0 & 0 & 0 & 0 & 0 & 0 & 0 & 0 & 0 & 0 & 0 & 0 \\
\hline $\begin{array}{l}\text { TOTAL } \\
\text { Revenue }\end{array}$ & 0 & 0 & 0 & 0 & 0 & 0 & 0 & 0 & 0 & 0 & 0 & 0 & 0 & 0 & 0 \\
\hline \multicolumn{16}{|l|}{ Expenditures } \\
\hline Investment Cost & $6,210,184$ & 0 & 0 & 0 & 0 & 0 & 0 & 0 & 0 & 0 & 0 & 0 & 0 & 0 & 0 \\
\hline Operating Cost & 0 & $4,441,402$ & $4,441,402$ & $4,441,402$ & $4,441,402$ & $4,441,402$ & $4,441,402$ & $4,441,402$ & $4,441,402$ & $4,441,402$ & $4,441,402$ & $4,441,402$ & $4,441,402$ & $4,441,402$ & $4,441,402$ \\
\hline $\begin{array}{c}\text { TOTAL } \\
\text { Expenditure }\end{array}$ & $6,210,184$ & $4,441,402$ & $4,441,402$ & $4,441,402$ & $4,441,402$ & $4,441,402$ & $4,441,402$ & $4,441,402$ & $4,441,402$ & $4,441,402$ & $4,441,402$ & $4,441,402$ & $4,441,402$ & $4,441,402$ & $4,441,402$ \\
\hline $\begin{array}{c}\text { NET CASH } \\
\text { FLOW }\end{array}$ & $\begin{array}{c}- \\
6,210,184\end{array}$ & 4,441,402 & $4,441,402$ & $4,441,402$ & $\begin{array}{c}- \\
4,441,402\end{array}$ & 4,441,402 & $4,441,402$ & $4,441,402$ & $4,441,402$ & $4,441,402$ & 4,441,402 & $\begin{array}{c}- \\
4,441,402\end{array}$ & $\begin{array}{c}- \\
4,441,402\end{array}$ & $\begin{array}{c}- \\
4,441,402\end{array}$ & $4,441,402$ \\
\hline
\end{tabular}


Table 5.48. Cash flow (USD) assessment for activated sludge with peroxone alternative

\begin{tabular}{|c|c|c|c|c|c|c|c|c|c|c|c|c|c|c|c|}
\hline $\begin{array}{l}\text { YEARS } \\
\end{array}$ & 2008 & 2009 & 2010 & 2011 & 2012 & 2013 & 2014 & 2015 & 2016 & 2017 & 2018 & 2019 & 2020 & 22021 & 2022 \\
\hline \multicolumn{16}{|l|}{ Revenues } \\
\hline Water Recovery & 0 & 0 & 0 & 0 & 0 & 0 & 0 & 0 & 0 & 0 & 0 & 0 & 0 & 0 & 0 \\
\hline $\begin{array}{c}\text { Reduction in } \\
\text { WW }\end{array}$ & 0 & 0 & 0 & 0 & 0 & 0 & 0 & 0 & 0 & 0 & 0 & 0 & 0 & 0 & 0 \\
\hline $\begin{array}{l}\text { TOTAL } \\
\text { Revenue }\end{array}$ & 0 & 0 & 0 & 0 & 0 & 0 & 0 & 0 & 0 & 0 & 0 & 0 & 0 & 0 & 0 \\
\hline \multicolumn{16}{|l|}{ Expenditures } \\
\hline Investment Cost & $6,210,184$ & 0 & 0 & 0 & 0 & 0 & 0 & 0 & 0 & 0 & 0 & 0 & 0 & 0 & 0 \\
\hline Operating Cost & 0 & $6,157,859$ & $6,157,859$ & $6,157,859$ & $6,157,859$ & $6,157,859$ & $6,157,859$ & $6,157,859$ & $6,157,859$ & $6,157,859$ & $6,157,859$ & $6,157,859$ & $6,157,859$ & $6,157,859$ & $6,157,859$ \\
\hline $\begin{array}{c}\text { TOTAL } \\
\text { Expenditure }\end{array}$ & $6,210,184$ & $6,157,859$ & $6,157,859$ & $6,157,859$ & $6,157,859$ & $6,157,859$ & $6,157,859$ & $6,157,859$ & $6,157,859$ & $6,157,859$ & $6,157,859$ & $6,157,859$ & $6,157,859$ & $6,157,859$ & $6,157,859$ \\
\hline $\begin{array}{c}\text { NET CASH } \\
\text { FLOW }\end{array}$ & $\begin{array}{c}- \\
6,210,184\end{array}$ & $6,157,859$ & $\begin{array}{c}- \\
6,157,859\end{array}$ & $6,157,859$ & $6,157,859$ & $\begin{array}{c}- \\
6,157,859\end{array}$ & $\begin{array}{c}- \\
6,157,859\end{array}$ & $\begin{array}{c}- \\
6,157,859\end{array}$ & $\begin{array}{c}- \\
6,157,859\end{array}$ & $6,157,859$ & $\begin{array}{c}- \\
6,157,859\end{array}$ & $\begin{array}{c}- \\
6,157,859\end{array}$ & $6,157,859$ & $\begin{array}{c}- \\
6,157,859\end{array}$ & $\begin{array}{c}- \\
6,157,859\end{array}$ \\
\hline
\end{tabular}


Table 5.49. Cash flow (USD) assessment for ozonation after activated sludge alternative

\begin{tabular}{|c|c|c|c|c|c|c|c|c|c|c|c|c|c|c|c|}
\hline $\begin{array}{l}\text { YEARS } \\
\end{array}$ & 2008 & 2009 & 2010 & 2011 & 2012 & 2013 & 2014 & 2015 & 2016 & 2017 & 22018 & 2019 & 2020 & 2021 & 2022 \\
\hline \multicolumn{16}{|l|}{ Revenues } \\
\hline Water Recovery & 0 & 0 & 0 & 0 & 0 & 0 & 0 & 0 & 0 & 0 & 0 & 0 & 0 & 0 & 0 \\
\hline $\begin{array}{c}\text { Reduction in } \\
\text { WW }\end{array}$ & 0 & 0 & 0 & 0 & 0 & 0 & 0 & 0 & 0 & 0 & 0 & 0 & 0 & 0 & 0 \\
\hline $\begin{array}{l}\text { TOTAL } \\
\text { Revenue }\end{array}$ & 0 & 0 & 0 & 0 & 0 & 0 & 0 & 0 & 0 & 0 & 0 & 0 & 0 & 0 & 0 \\
\hline \multicolumn{16}{|l|}{ Expenditures } \\
\hline Investment Cost & $1,711,541$ & 0 & 0 & 0 & 0 & 0 & 0 & 0 & 0 & 0 & 0 & 0 & 0 & 0 & 0 \\
\hline Operating Cost & 0 & $2,027,693$ & $2,027,693$ & $2,027,693$ & $2,027,693$ & $2,027,693$ & $2,027,693$ & $2,027,693$ & $2,027,693$ & $2,027,693$ & $2,027,693$ & $2,027,693$ & $2,027,693$ & $2,027,693$ & $2,027,693$ \\
\hline $\begin{array}{c}\text { TOTAL } \\
\text { Expenditure }\end{array}$ & $1,711,541$ & $2,027,693$ & $2,027,693$ & $2,027,693$ & $2,027,693$ & $2,027,693$ & $2,027,693$ & $2,027,693$ & $2,027,693$ & $2,027,693$ & $2,027,693$ & $2,027,693$ & $2,027,693$ & $2,027,693$ & $2,027,693$ \\
\hline NET CASH & & & & & & & & & & & & & & & \\
\hline FLOW & $1,711,541$ & $2,027,693$ & $2,027,693$ & $2,027,693$ & $2,027,693$ & $2,027,693$ & $2,027,693$ & $2,027,693$ & $2,027,693$ & $2,027,693$ & $2,027,693$ & $2,027,693$ & $2,027,693$ & $2,027,693$ & $2,027,693$ \\
\hline
\end{tabular}




\subsubsection{Net Present Value (NPV)}

NPV calculations were done for each of the treatability alternative by using the Equation (5) mentioned before. Discount rate was assumed as $10 \%$ and the economic life of the alternatives was taken as 15 years. These evaluated NPV results are given in Table 5.50.

Table 5.50. NPV values of the wastewater treatability alternatives

\begin{tabular}{cc}
\hline \hline Alternative Options & NPV \\
& (USD) \\
\hline \hline Activated Sludge + MF + NF & $-2,992,510$ \\
\hline Membrane Bioreactor & $2,925,140$ \\
\hline Ozonation + Activated Sludge & $-35,389,643$ \\
\hline Peroxone + Activated Sludge & $-46,884,731$ \\
\hline Activated Sludge + Ozonation & $-15,135,382$ \\
\hline \hline
\end{tabular}

\subsubsection{Internal Rate of Return}

In addition to cash flow analysis and NPV determination, the IRR for such investments were evaluated and presented in Table 5.51. As can be seen from this table, the IRR of the alternatives which were ozonation peroxone after and before the activated sludge system could not be able to be determined since they did not have revenues in fact they did not provide any water recovery. On the other hand, although application of membrane filtration processes after the activated sludge system provided revenue to the selected textile mill, the IRR of this alternative was not also be determined. The reason for this is that their revenues provided were less 
than the expenditures due to operating cost. The only calculated IRR value was for the membrane bioreactor alternative. The Table 5.51 below shows the IRR values of the alternatives taken under consideration for treatability studies.

Table 5.51. IRR values of the wastewater treatability alternatives

\begin{tabular}{cc}
\hline Alternative Options & $\begin{array}{c}\text { IRR } \\
(\%)\end{array}$ \\
\hline Activated Sludge + MF + NF & N/A \\
\hline Membrane Bioreactor & 24 \\
\hline Ozonation + Activated Sludge & N/A \\
\hline Peroxone + Activated Sludge & N/A \\
\hline Activated Sludge + Ozonation & N/A \\
\hline \hline
\end{tabular}

\subsubsection{Annual Cost Calculations}

By converting all the cash flows to equivalent annual cost, annual costs of each alternative were evaluated. Equation (7) was used for the annual cost determination and the calculated annual costs were given in Table 5.52. 
Table 5.52. Annual costs of the wastewater treatability alternatives

\begin{tabular}{ccc}
\hline \hline & $\begin{array}{c}\text { Capital } \\
\text { Recovery } \\
\text { Alternative Options }\end{array}$ & $\begin{array}{c}\text { Annual Costs } \\
\text { Factor } \\
(\boldsymbol{\%})\end{array}$ \\
\hline (USD) \\
\hline Activated Sludge + MF + NF & 13 & $1,719,564$ \\
\hline Ozembrane Bioreactor & 13 & 863,747 \\
\hline Peroxone + Activated Sludge & 13 & $5,118,091$ \\
\hline Activated Sludge + Ozonation & 13 & $6,780,524$ \\
\hline \hline
\end{tabular}

\subsubsection{Evaluation of the Wastewater Treatability Alternatives}

\subsubsection{Cost Effectiveness and Benefit Analysis}

The calculated cost effectiveness values for wastewater treatability alternatives are given in Table 5.53. By evaluating the cost effectiveness, it can be understood which alternatives would be preferable to reach a specific environmental target at the lowest cost. 
Table 5.53. Cost effectiveness of the wastewater treatability alternatives

\begin{tabular}{cccc}
\hline \hline Alternative Options & $\begin{array}{c}\text { Annual } \\
\text { Costs } \\
\text { (USD) }\end{array}$ & $\begin{array}{c}\text { Annual } \\
\text { Reduction } \\
\text { of COD } \\
\text { (kg/year) }\end{array}$ & $\begin{array}{c}\text { Cost } \\
\text { Effectiveness } \\
\text { (USD/kg COD } \\
\text { reduced) }\end{array}$ \\
\hline \hline Activated Sludge + MF + NF & $1,738,425$ & $1,921,725$ & 0.89 \\
\hline Membrane Bioreactor & 863,747 & $2,079,258$ & 0.42 \\
\hline Ozonation + Activated Sludge & $5,737,486$ & $1,003,568$ & 5.10 \\
\hline Peroxone + Activated Sludge & $7,439,956$ & $1,003,568$ & 6.76 \\
\hline Activated Sludge + Ozonation & $2,255,637$ & $1,067,625$ & 2.05 \\
\hline
\end{tabular}

As can be seen from Table 5.53 that fourth alternative which is peroxone with activated sludge treatment has the highest cost effectiveness which means that fourth alternative needs the highest amount of money in order to reach the requirements. Therefore, it can be concluded that the second one which is MBR application could be thought to be the best alternative in terms of cost effectiveness. 


\subsection{Sensitivity Analysis}

In this thesis, in addition to the cost-benefit analysis, sensitivity analysis was also performed for each of the alternative options considered in both water recovery studies and wastewater treatability studies. Sensitivity analysis is the method that aims at identifying the project's critical variables [40]. This is done by letting the project variables vary according to a given percentage change and observing the subsequent variations in financial indicators. In other words, it provides data in order to make decision that shows how the economic variables would change when key project factors vary from their estimated values [51].

There were six variables assumed as critical in the financial analysis for both of the studies considered in this thesis. These were influent COD value of the wastewater, influent color value of the wastewater, discount rate, unit energy cost, total operating cost index, and exchange rate variation.

Here, total operating cost index was the percentage that would be applied in the cash flow analysis for the operating cost value. If it was assumed as zero, then operating costs would not change in 15 years period thus it would remain constant through years. However, if it was assumed any percentage rather than zero, then the operating cost would change according to this assumed percentage in years.

In this analysis, arbitrarily chosen percentage changes or values were assumed for each of these critical variables. Sensitivity analysis was performed with respect to the following variations. Maximum, average, and minimum values for COD and color concentrations are illustrated in Table 5.54.

- maximum, average, and minimum values of COD,

- maximum, average, and minimum values of color, 
- $6 \%, 8 \%$, and $10 \%$ of discount rate,

- $0 \%, 5 \%$, and $10 \%$ change observed in the energy costs,

- $0 \%, 1 \%$, and $2 \%$ variations observed in total operating cost index and exchange rate.

Table 5.54. COD and color concentrations for sensitivity analysis

\begin{tabular}{|c|c|c|c|c|}
\hline & & $\begin{array}{c}\text { Dyeing } \\
\text { Wastewaters }\end{array}$ & $\begin{array}{c}\text { Wastewaters } \\
\text { before } \\
\text { Activated } \\
\text { Sludge } \\
\text { System }\end{array}$ & $\begin{array}{c}\text { Wastewaters } \\
\text { after } \\
\text { Activated } \\
\text { Sludge } \\
\text { System }\end{array}$ \\
\hline \multirow{3}{*}{$\begin{array}{c}\text { COD } \\
(\mathrm{mg} / \mathrm{L})\end{array}$} & Max & 1,600 & 3,200 & 900 \\
\hline & Avg & 850 & 350 & 750 \\
\hline & Min & 1,200 & 1,800 & 800 \\
\hline \multirow{3}{*}{$\begin{array}{c}\text { Color } \\
\text { (Pt-Co) }\end{array}$} & Max & 7,000 & 5,000 & 4,000 \\
\hline & Avg & 3,000 & 2,500 & 1,600 \\
\hline & Min & 5,000 & 3,800 & 2,100 \\
\hline
\end{tabular}

By changing the critical variables' value, the percentage change in investment costs, operating costs, and net present values were evaluated, and plotted in a diagram which is called as sensitivity diagram. All the sensitivity diagrams of the alternatives considered in the water recovery and wastewater treatability studies are illustrated in Appendix D. A sample working sheet used in the analysis is given in Appendix C (Figure C.1). 
The slopes of the different lines represented which variable had the greatest impact on financial results. Moreover, the greater the variation of the line, the larger the economic impact. As can be seen from the diagrams in Appendix D, the greatest impact on the investment costs was determined due to the variation in the exchange rate in all of the alternative options whereas operating costs of all of the alternatives affected mostly by energy cost change. On the other hand, discount rate only affected the net present values of the alternatives. The calculated percentage changes for the investment costs, operating costs, and net present values for the alternatives are also given in Appendix E. 


\subsection{Risk Evaluation}

Risk evaluation is the assessment of the impact of given percentage changes in a variable on the project's performance indicators [40]. In cases where project results are expected to be particularly sensitive to certain variables, it has to be assessed how likely it is that such changes would occur. Therefore, after the sensitivity analysis, risk evaluation was done in this thesis.

As indicated in the sensitivity analysis, for the water recovery and wastewater treatability studies percentage changes were evaluated and given in Appendix E. According to these percentages, it can be seen that influent COD concentration variation would not affect the investment and operating costs for the membrane based alternatives which were membrane filtration alternatives and membrane bioreactor application. However, alternatives consisting of ozonation processes were changed with respect to the change in COD concentrations. For instance, $33 \%$ increase in COD concentration changed the investment cost of the ozonation alternative in the water recovery studies by $19 \%$. Moreover, in the wastewater treatability alternatives, investment cost of the ozonation process applied before the activated sludge system decreased by $59 \%$ with the $81 \%$ decrease in the COD concentration. Therefore, it can be concluded that COD concentration could be assumed as a risk element of the ozonation processes. Compared to the investment and operating costs, NPV of the ozonation alternative was not so much affected with the COD concentration variation.

In this thesis, it was observed that color was not a determining factor as well as it was not a critical variable in the sensitivity analysis. Only the treatment efficiency was affected by the color variation. However, color concentration can be thought as a risk element in terms of aesthetic requirements. 
Furthermore, the discount rate was examined as a fundamental means of reflecting risk in discounted cash flow evaluations. Change in discount rate affected the net present value in all the alternatives applied for water recovery and wastewater treatability studies. As an example, $20 \%$ change in discount rate had an approximately $33 \%$ impact on the cash flow analysis in the membrane bioreactor alternative considered in the treatability studies. In addition to discount rate, total operating cost index was investigated as a risk element, since it affected the net present values high in amount with only $1 \%$ change.

If the energy costs were changed by $5 \%$, the operating costs would be affected similarly. Therefore, it was assessed that change in the energy costs did not have high impact on the operating costs. Thus it would not be thought as a risk element. This case is the same for the exchange rate variation effect on the investment costs, operating costs, and net present values. 


\subsection{Economic Viability of the Textile Sector}

As indicated in the previous chapters, according to the IPPC Directive, the selected BAT should be technically and economically viable for the relevant sector. Therefore, it is important to assess the economic viability of the textile sector. In the Reference Document, in order to evaluate the economic viability, some issues are introduced which are industry structure, market structure, resilience, and speed of the implementation of IPPC Directive.

Textile industry takes the third place of the World market after tourism and information sector, with an approximate total sale of 1.7 trillion USD [52]. There exist five main factors that affect the textile industry which are:

- Industrial trend,

- World trade,

- Trends among consumers,

- Retail market,

- Technological development [50].

The textile sector is one of the major industries for the Turkish economy. Moreover, it has also taken an important share in the world trade. At the beginning of the 1980s, the total value of Turkish textile exports equalled to 190 million USD. However, in 1999, this value increased sharply to 9.8 billion USD [53].

On the other hand, as a more capital intensive industry as compared to other industries, most of the companies in this sector are mainly medium scale. The industry has also large scale companies having integrated production facilities one of which is the textile mill considered in this project. As indicated before, the selected textile mill is one of the world's leading denim producer companies [54]. 
The estimated investment costs needed for the implementation of both water recovery and wastewater treatability alternatives were generally high in value. However, the selected textile mill would probably handle them. Moreover, some of the alternatives indicated can offset the initial high cost of implementing process in the long run by providing water recovery with greater efficiency.

Re-known as one of the major innovation leaders of jeans and sportswear, the selected mill has the vision of "to be a model company internationally in the sportswear sector in terms of business excellence". The company's mission is "as a preferred supplier to manufacturers of sportswear clothing, who give priority to quality and creativity, our basic task is to be able to plan, sustain and create high economic value" [55]. Moreover, the textile mill considered is in Turkey's top list of 500 firms with a ranking of 99. It has a net sale of 230,152,854 YTL [56]. With this vision and mission, the company is currently one of the leading companies in the markets in which they offer service. However, as it is well known, the Turkish Textile Sector is adversely affected by the China's membership in the World Trade Organization (WTO) in 2001. Particularly the removal of the quotas on textiles starting from the beginning of 2005 under the WTO Agreement, has negatively affected the textile production and exports of the developing countries [57].

Furthermore, the implementation of IPPC Directive in Turkey has not started yet. However, the transposition of the Directive is in the priority list of the Ministry of Environment and Forestry of Turkey (MoEF). In the Annual Report of 2007, it was stated that all the industrial facilities would apply IPPC Directive in the year of 2023 [58]. 


\section{CHAPTER 6}

\section{SUMMARY}

In this thesis, the best water and wastewater management alternatives for the selected textile mill located in Kayseri were evaluated according to the requirements in the IPPC Directive. For this purpose, water recovery alternatives and wastewater treatability alternatives were studied under the project of "Adaptation of IPPC Directive to a Textile Mill in Turkey" conducted by METU.

These alternatives were assessed in terms of their environmental benefits and financial values according to the suggested guidelines in the Reference Document on "Economics and Cross-Media Effect". Initially, environmental effects were determined for each of the alternatives. Then, the considered alternatives were financially evaluated. Moreover, sensitivity analysis was carried out with the assessment of the risks.

As indicated previously, according to the IPPC Directive, BAT should be the technique that can be applied under technically and economically viable conditions by achieving high level of environmental protection. For this purpose, in this thesis, while determining the BAT for both of the studies, namely water recovery studies and wastewater treatability studies, technically applicable alternatives which were thought to be BAT were assessed in terms of environmental benefits and economic feasibility according to the methodologies stated in the Reference Document. 
In the water recovery studies, two technically applicable alternatives were evaluated. It was seen that the lower the environmental effect of the alternative, the lower the investment and operating costs were determined. In other words, membrane filtration processes used in the water recovery studies had lower effects on the environment rather than the ozonation process. In addition to this, both the investment and operating costs of the ozonation process were estimated at higher values than the costs for the membrane filtration processes. Then, among the water recovery alternatives, membrane filtration process chain composed of MF and NF appeared to be the BAT for reusing of dyeing wastewaters.

Similarly, the same analysis was performed in order to assess the BAT for end-ofpipe treatment of the mixed wastewater from the mill. The membrane bioreactor application was determined as BAT among the wastewater treatment alternatives. The environmental effects of the membrane bioreactor alternative were lower than those for the other alternatives. On the other hand, the investment and operating costs calculated for this alternative was the lowest among the other options.

As regards the adaptation of the IPPC Directive, it is necessary to set effluent criteria in the permit that would be given on the bases of BAT application. Therefore, it is needed to determine a single set of BATs for the mill. In the present study, the two alternatives investigated were compared in this respect. Table 6.1 and 6.2 present the summaries of this comparison. 
Table 6.1. Summary of cross-media effects for the selected BATs

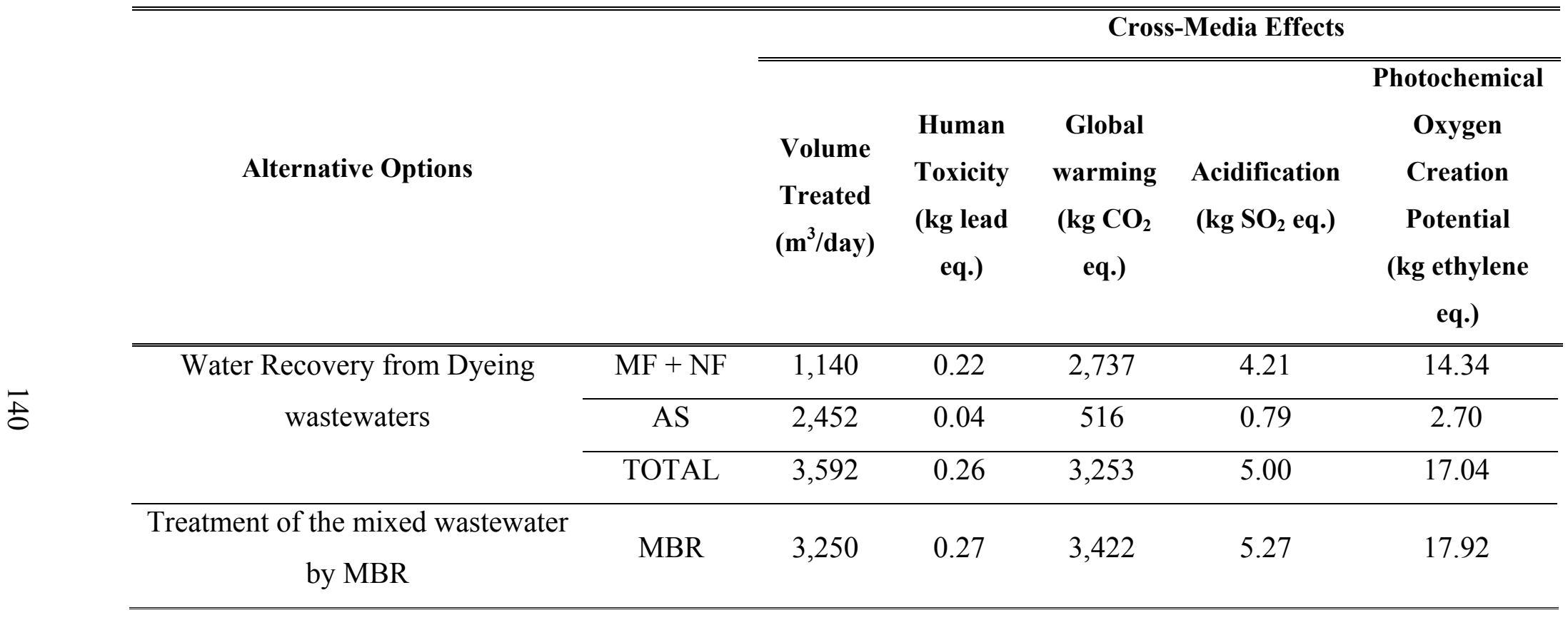


Table 6.2. Summary of financial analysis for the selected BATs

\begin{tabular}{|c|c|c|c|c|c|c|c|}
\hline \multirow[b]{2}{*}{ Alternative Options } & & \multicolumn{5}{|c|}{ Financial Analysis } & \multirow[b]{2}{*}{$\begin{array}{c}\text { Cost } \\
\text { effectiveness } \\
\text { (USD/kg } \\
\text { COD } \\
\text { removed) }\end{array}$} \\
\hline & & $\begin{array}{c}\text { Investment } \\
\text { Cost } \\
\text { (USD) }\end{array}$ & $\begin{array}{c}\text { Operating } \\
\text { Cost } \\
\left(\mathrm{USD} / \mathbf{m}^{3}\right)\end{array}$ & $\begin{array}{c}\text { Net } \\
\text { present } \\
\text { value } \\
\text { (USD) }\end{array}$ & $\begin{array}{c}\text { Internal } \\
\text { Rate of } \\
\text { Return } \\
(\%)\end{array}$ & $\begin{array}{c}\text { Annual } \\
\text { Cost } \\
\text { (USD) }\end{array}$ & \\
\hline \multirow{3}{*}{$\begin{array}{l}\text { Water Recovery from } \\
\text { Dyeing wastewaters }\end{array}$} & $\mathrm{MF}+\mathrm{NF}$ & 632,950 & 0.60 & $1,201,370$ & 42 & 277,621 & 0.59 \\
\hline & $\mathrm{AS}$ & & 0.87 & & *** & & \\
\hline & TOTAL & 632,950 & $0.78^{*}$ & 558,566 & 26 & 370,584 & 0.27 \\
\hline Treatment of the mixed & & & & & & & \\
\hline $\begin{array}{l}\text { wastewater } \\
\text { by MBR }\end{array}$ & MBR & $3,761,574$ & 0.64 & $2,925,140$ & 24 & 863,747 & 0.42 \\
\hline
\end{tabular}

* Calculations are given in Appendix F.

${ }^{* *}$ Since the activated sludge plant exists, the values were not calculated. 
As can be depicted from the tables; membrane filtration application for water recovery from dyeing wastewater is superior to MBR application for the mixed wastewater with respect to both cross-media effects and financial analysis performed. It can be seen from Table 6.1 that the environmental effects of both the application of membrane filtration processes to dyeing wastewaters and the treatment of the other wastewater streams with the existing activated sludge system are less than those for MBR alternative applied for the mill's mixed wastewater. Moreover, as can be concluded from Table 6.2, membrane filtration alternative for dyeing process is more economically viable alternative.

According to the sensitivity analysis, for both of the BATs, investment costs were mainly sensitive to exchange rate variations. On the other hand, operating cost could change due to the variation in energy costs. Moreover, net present values of the BATs were sensitive to the change in discount rate. For instance, Figure 6.1 and Figure 6.2 show the investment cost sensitivity diagrams for membrane filtration alternative and MBR alternative, respectively. 


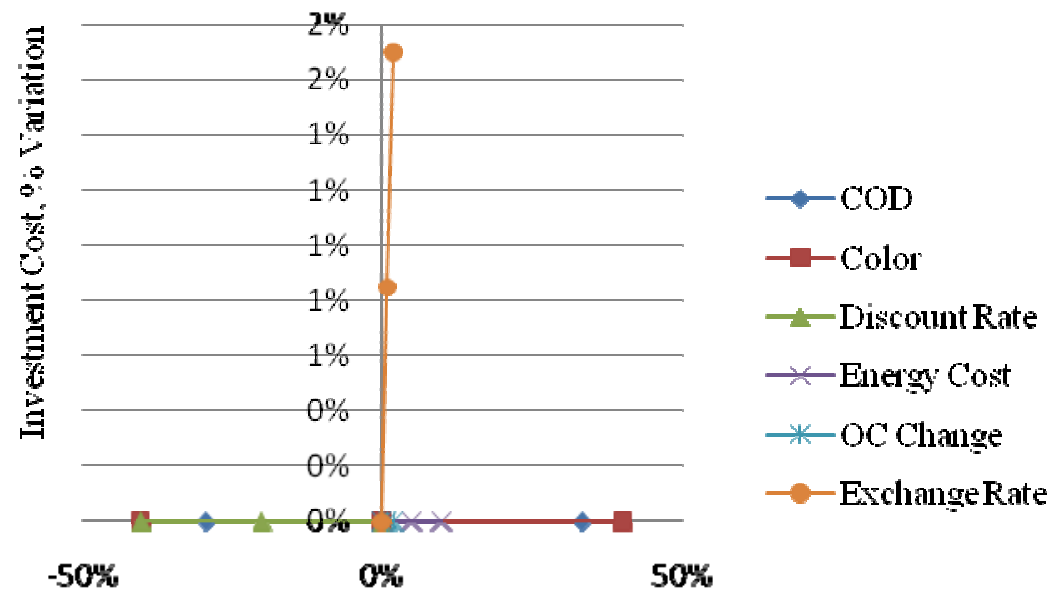

Other Variables, :- Variation

Figure 6.1. Investment cost sensitivity diagram for MF $+\mathrm{NF}$ alternative applied in water recovery studies

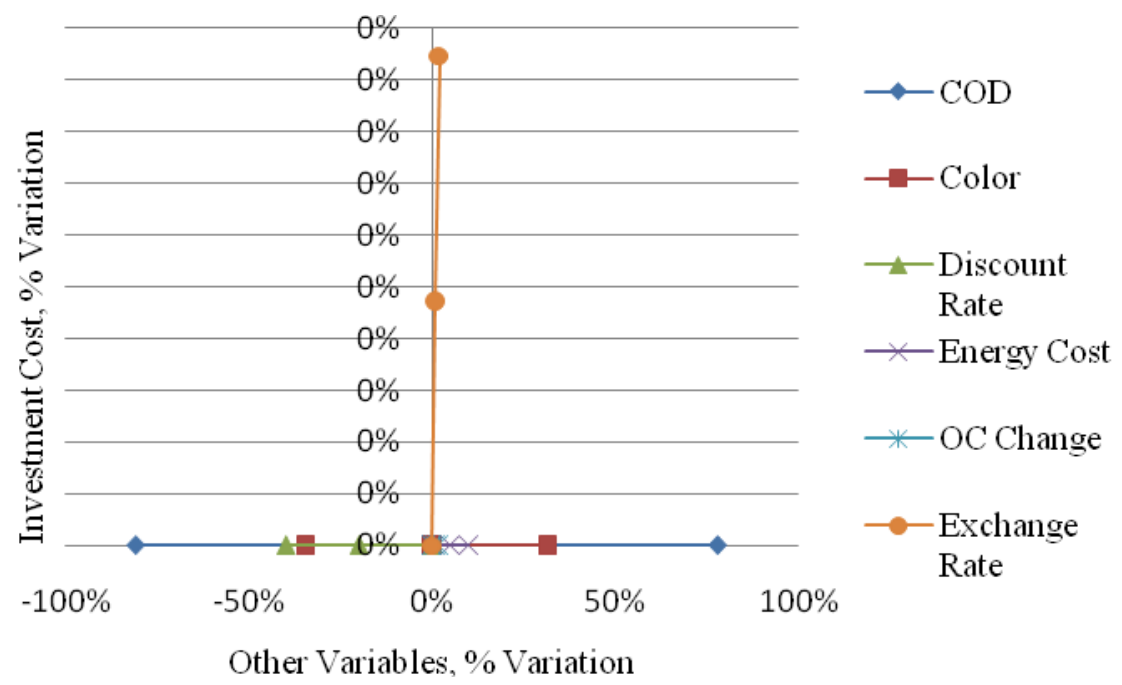

Figure 6.2. Investment cost sensitivity diagram for the MBR alternative applied in wastewater treatability studies 


\section{CHAPTER 7}

\section{CONCLUSIONS}

Based on the results obtained in the previous chapters, the following conclusions can be done from this thesis

- Among two water recovery alternatives which were membrane filtration and ozonation considered in the cost-benefit analysis, membrane filtration process chain composed of MF proceeded by NF, was determined as the best water management alternative due to its low cost and low adverse environmental effects. This alternative provided a water recovery of $70 \%$.

- MBR process was found to be the best treatment alternative for the mixed wastewater. The other alternatives considered were activated sludge followed by membrane filtration, activated sludge followed by ozonation, ozonation and peroxone followed by activated sludge. MBR selected as the BAT not only due its high cost-benefit ratio but also water recovery potential.

- Finally, among membrane filtration for water recovery and MBR treatment of the mixed wastewater, the former was selected as the BAT applicable for the mill in consideration.

- Since for both of the options, the selected BATs were based on membrane technology, membrane technology appeared to be the most promising 
alternative in terms of recovery and treatability. In addition, this technology is also economically applicable.

- Economic viability of the sector was also investigated in this thesis. Most of the textile mills in Turkey are in medium scale. However, the selected mill in this study is one of the world's leading denim producers. Therefore, it was thought that the selected mill would afford the investment need for the selected BAT which is 632,950 USD. In addition, by applying this alternative, the mill could get some revenues originated for the water recovery.

- According to the sensitivity analysis conducted in order to quantify the level of risk in the study, influent COD concentration, influent color value, discount rate, energy cost, total operating cost index, and exchange rate variation were thought as the critical variations in the studies. Among these critical variations, it was investigated from the sensitivity diagrams that investment costs were mainly affected by the exchange rate variations. On the other hand, the greatest impact on operating cost was due to the variation in energy costs. Moreover, net present values of the alternatives were sensitive to the change in discount rate.

- Some of the considered critical values were thought as the risk elements such as initial COD concentration, discount rate, and total operating cost index. Little change in these values affected the investment costs, operating costs, and net present values. On the other hand, variations in the influent color value, energy costs, and exchange rate changes did not have significant influences on these financial indicators. 


\section{CHAPTER 8}

\section{RECOMMENDATIONS}

In addition to the abovementioned conclusions, all the analyses performed in this thesis were mainly based on assumptions. The reason for this is that the alternatives considered both in the water recovery and wastewater treatability studies are very new technologies started to be applied not only in the textile industry, but also in the other treatment fields. Therefore, more realistic cost figures can be found for those alternatives in the future studies. In addition, by increasing in the implementation of these ones in the future, the costs would decrease which would result in more water recovery.

Moreover, as can be concluded from this thesis that saving water is a very important issue for textile installations since water consumption is very high in amount in their sector. By means of water recovery, textile mills not only save water, but also they save money. From this point of view, textile industry should be made conscious of water recovery management techniques. 


\section{REFERENCES}

[1] Council Directive 96/61/EC of 24 September 1996 concerning integrated pollution prevention and control, 24 September 1996.

[2] Integrated pollution prevention and control, Reference Document on "Economics and Cross-Media Effects", July 2006.

[3] Ministry of Environment and Forestry, Technical Assistance for Environmental Heavy-Cost Investment Planning, Directive-Specific Investment Plan for the Council Directive 96/61/EC of 24 September 1996 concerning Integrated Pollution Prevention and Control, September 2005.

[4] Alaton I. A., Insel G., Eremektar G., Babuna F., Orhon D. Effect of textile auxiliaries on the biodegradation of dyehouse effluent in activated sludge. Chemosphere, 62:1549-1577, 2006.

[5] El-dein A. M., Libra J., Wiesman U. Cost analysis or the degradation of highly concentrated textile dye wastewater with chemical oxidation H2O2/UV and biological treatment. Journal of Chemical Technology and Biotechnology, 81:1239$1245,2006$.

[6] Confidential Wastewater Treatment Plant Reports, Ministry of Environment and Forestry, Turkey, 2008. 
[7] Erdogan A. O., Orhon H. F., Dulkadiroglu H., Dogruel S., Eremektar G., Babuna F. G., Orhon D. Feasibility analysis of in-plant control for water minimization and wastewater reuse in a wool finishing textile mill. Journal of Environmental Science \& Health, A39:1819-1832, 2004.

[8] Soares O. S., Orfao J. M., Portela D., Vieira A., Pereira M. Ozonation of textile effluents and dye solutions under continuous operation: Influence of operating parameters. Journal of Hazardous Materials, B137:1664-1673, 2006.

[9] Tabrizi G. B., Mehrvar M. Integration of advanced oxidation technologies and biological processes: recent developments, trends, and advances. Journal of Environmental Science and Health, A39 (11-12): 3029-3081, 2004.

[10] Vandevivere P., Bianchi R., Verstraete W., Treatment and reuse of wastewater from textile wet-processing industry: review of emerging technologies. Journal of Chemical Technology and Biotechnology, 72:289-302, 1998.

[11] Munter R. Advanced oxidation processes - current status and prospects. Proceeding of the Estonian Academy of Sciences Chemistry, 50 (2): 59-80, 2001.

[12] Canizares P., Paz R., Saez C., Rodrigo M. A., Costs of the electrochemical oxidation of wastewaters: A comparison with ozonation and Fenton oxidation processes, Journal of Environmental Management, In press, Corrected Proof, 2008.

[13] Buffle M., Schumacher J., Meylan S., Jekel M., Gunten U. Ozonation and advanced oxidation of wastewater effect of $\mathrm{O}^{3}$ Dose, $\mathrm{pH}$, DOM, and $\mathrm{HO}^{-}-$ scavengers on ozone decomposition and $\mathrm{HO}$ generation. Ozone: Science and Engineering, 28:247-259, 2006. 
[14] Mock B., Hamouda H. Ozone application to color destruction of industrial wastewater - Part 1. Experimental. American Dyestuff Reporter, Raleigh, August 1998.

[15] Solmaz S., Birgul A., Ustun G., Yonar T. Color and COD removal from textile effluent by coagulation and advanced oxidation processes. Coloration Technology, 122:102-109, 2006.

[16] Boncz M. Selective oxidation of organic compounds in wastewater by ozonebased oxidation processes. $\mathrm{PhD}$ Thesis, Wageningen University, Wageningen, the Netherlands, 2002.

[17] Lin S. H., Peng C. F. A continuous Fenton's process for treatment of textile wastewater. Environmental Technology, 16:693-699, 1995.

[18] Case Studies Report, Color Reduction and Removal Seminar, North Carolina, 1998.

[19] Montano J., Ruiz N., Munoz I., Domenech X., Garcia-Hortal J., Torrades F., Peral J., Environmental assessment of different photo-Fenton approaches for commercial reactive dye removal. Journal of Hazardous Materials, 138:218-225, 2006.

[20] Ustun G., Solmaz S., Birgul A., Regeneration of industrial district wastewater using a combination of Fenton process and ion exchange - a case study. Resources Conservation and Recycling, 52:425-440, 2007. 
[21] Al-kdasi A., Idris A., Saed K., Guan C. T. Treatment of textile wastewater by advanced oxidation processes - a review. Global Nest: the International Journal, 6 (3): 222-230, 2004.

[22] Tizaoui C., Bouselmi L., Mansouri L., Ghrabi A., Landfill leachate treatment with ozone and ozone/hydrogen peroxide systems. Journal of Hazardous Materials, 140:316-324, 2007.

[23] Marcucci M., Ciabatti I., Matteucci A., Vernaglione G. Membrane technologies applied to textile wastewater treatment. Annals of the New York Academy of Science, 984:53-64, 2003.

[24] Uzal N. Recovery and reuse of indigo dyeing wastewater using membrane technology, PhD thesis, Middle East technical University, Ankara, Turkey, 2007.

[25] Ng A., Kim A., A mini-review of modeling studies on membrane bioreactor (MBR) treatment for municipal wastewaters. Desalination, 212:261-281, 2007.

[26] Zheng X., Liu J., Dyeing and printing wastewater treatment using a membrane bioreactor with a gravity drain. Desalination, 190:277-286, 2007.

[27] Churchouse S., Wildgoose D. Membrane bioreactors progress from the laboratory to full-scale use. MBR Technology, Bristol, UK.

[28] Hafez A., Khedr M., Gadallah H., Wastewater treatment and water reuse of food processing industries. Part 2: Techno-economic study of a membrane separation technique. Desalination, 214:261-272, 2007. 
[29] Efficient use of water in the textile finishing industry. E-Water, European Water Association, 2005.

[30] Florio L., Giordano A., Mattioli D., Nanofiltration of low-contaminated textile rinsing effluents for on-site treatment and reuse. Desalination, 181:283-292, 2005.

[31] Marcucci M., Ciardelli G., Matteucci A., Ranieri L., Russo M., Experimental campaigns on textile wastewater for reuse by means of different membrane processes. Desalination, 149:137-143, 2002.

[32] Guiziou G. G., Alvarez N., Jacob D., Daufin G. Cleaning-in-place coupled with membrane regeneration for re-using caustic soda solutions. Separation Purification Technology, 54:329-339, 2007.

[33] Gorenflo A., Velazquez-Padron D., Frimmel F. H. Nanofiltration of a German groundwater of high hardness and NOM content: performance and costs. Desalination, 151:253-265, 2002.

[34] Van der Bruggen B., Everaert K., Wilms D., Vandecasteele C., Application of nanofiltration for removal of pesticides, nitrate and hardness from ground water: rejection properties and economic evaluation, Journal of Membrane Science, 193:239-248, 2001.

[35] Mavrotas G., Georgopoulou E., Mirasgedis S., Sarafidis Y., Lalas D., Hontou V., Gakis N., An integrated approach for the selection of Best Available Techniques (BAT) for the industries in the greater Athens area using multi-objective combinatorial optimization. Energy Economics, 29(4):953-973, 2007. 
[36] European Commission, http://ec.europa.eu/environment/air/pollutants/ stationary/ippc/summary.htm, last accessed on 12/08/2008.

[37] Dijkmans R., Methodology for selection of best available techniques (BAT) at the sector level, Journal of Cleaner Production, 8:11-21, 2000.

[38] European Comission, Integrated Pollution Prevention and Control Directive, Reference Document on "Best available techniques for the textile industry", July 2003.

[39] Georgopoulou E., Hontou V., Gakis N., Sarafidis Y., Mirasgedis S., Lalas D.P., Loukatos A., Gargoulas N., Mentzis A., Economidis D., Triantafilopoulos T., Korizi K., BEAsT: a decision-support tool for assessing the environmental benefits and the economic attractiveness of best available techniques in industry, Journal of Cleaner Production, 16(3):359-373, 2008.

[40] European Commission, Evaluation Unit, DG Regional Policy, "Guide to costbenefit analysis of investment projects", Bruxelles, 2002.

[41] European Commission, Evaluation Unit, DG Regional Policy, Guidance on the methodology for carrying out Cost-Benefit Analysis, 2007.

[42] Yigit N.O., Uzal N., Koseoglu H., Harman I., Yukseler H., Yetis U., Civelekoglu G., Kitis M., Treatment of a denim producing textile industry wastewater using pilot-scale membrane bioreactor (MBR), Desalination, In press.

[43] Takahashi N., Kumagai T., Removal of Dissolved Organic Carbon and Color from Dyeing Wastewater by Pre-ozonation and Subsequent Biological Treatment, Ozone. Science and Engineering, 28:199-205, 2006. 
[44] Adaptation of the IPPC Directive to a Textile Mill in Turkey, 105Y088 TUBITAK, Project Report, Ankara, Turkey, 2008.

[45] Tchobanoglous, G., Burton, F. L., Stensel, H. D., Wastewater Engineering Treatment and Reuse, 4th Ed., McGraw-Hill, New York, 2003.

[46] Munoz I., Peral J., Ayllon J. A., Malato S., Passarinho P., Domenech X., Life cycle assessment of a coupled solar photocatalytic-biological process for wastewater treatment, Water Research, 40:3533-3540, 2006.

[47] Dow Product and Services, "http.//www.dow.com/liquidseps/prod/nf270_400 htm", last accessed on 21/06/2008.

[48] Liikanena R., Yli-Kuivilab J., Tenhunenc J., Laukkanend R., Cost and environmental impact of nanofiltration in treating chemically pre-treated surface water, Desalination, 201:58-70, 2006.

[49] Badiru A. B., Omitaomu O. A., Computational Economic Analysis for Engineering Industry, CRC Press, New York, 2007.

[50] Kayseri Metropolitan Municipality Water and Sewerage Directorate, “http.//www.kaski.gov.tr/tr/fiyat.php”, last accessed on 23/06/2008.

[51] Brown T., Engineering Economics and Economic Design for Process Engineers, CRC Press, New York, 2007.

[52] Sekizinci Beş Yıllık Kalkınma Planı, Tekstil ve Giyim Snayi Özel İhtisas Komisyonu Raporu, Devlet Planlama Teşkilatı, Ankara, Turkey, 2001. 
[53] Akalin M. Insight into the Turkish textile and apparel industry, Electronic Journal of Textiles, 1(1), 2001.

[54] Turkish Textile Industry. Technical Report. İstanbul Tekstil ve Konfeksiyon İhracatçı Birlikleri Genel Sekreterliği, İstanbul, Turkey.

[55] Orta Anadolu Holding, "http://www.ortaanadolu.com/en/company-profile. aspx", last accessed on 21/08/2008.

[56] Sabah, "http://arsiv.sabah.com.tr/ozel/turkiyenin117/listebir.html”, last accessed on $21 / 08 / 2008$.

[57] Dokuzuncu Beş Yıllık Kalkınma Planı, Tekstil ve Giyim Snayi Özel İhtisas Komisyonu Raporu, Devlet Planlama Teşkilatı, Ankara, Turkey, 2006.

[58] Annual Report 2007, Ministry of Environment and Forestry, Turkey, 2007. 


\section{APPENDIX A}

WASTEWATER REUSE STANDARDS

Table A.1. Wastewater reuse criteria [54]

\begin{tabular}{cc}
\hline Parameters & Design Criteria \\
\hline \hline COD $(\mathrm{mg} / \mathrm{L})$ & 80 \\
\hline TSS $(\mathrm{mg} / \mathrm{L})$ & 5 \\
\hline TDS $(\mathrm{mg} / \mathrm{L})$ & 500 \\
\hline Hardness $\left(\mathrm{mg} / \mathrm{L}\right.$ as $\left.\mathrm{CaCO}_{3}\right)$ & 60 \\
\hline Conductivity $(\mu \mathrm{S} / \mathrm{cm})$ & 1,000 \\
\hline Alkalinity $\left(\mathrm{mg} / \mathrm{L}\right.$ as $\left.\mathrm{CaCO}_{3}\right)$ & - \\
\hline Color $(\mathrm{Pt}-\mathrm{Co})$ & 20 \\
\hline Turbidity $(\mathrm{NTU})$ & 1 \\
\hline $\mathrm{pH}$ & $6-8$ \\
\hline \hline
\end{tabular}




\section{APPENDIX B}

\section{DESIGN CRITERIA OF THE EXISTING WASTEWATER TREATMENT PLANT}

Table B.1. Design criteria of the existing wastewater treatment plant in the textile mill

\begin{tabular}{cc}
\hline \hline Parameters & Design Criteria \\
\hline \hline Flowrate $\left(\mathrm{m}^{3} /\right.$ day $)$ & 3,600 \\
\hline $\mathrm{COD}(\mathrm{mg} / \mathrm{L})$ & 2,800 \\
\hline $\mathrm{BOD}(\mathrm{mg} / \mathrm{L})$ & 1,100 \\
\hline $\mathrm{TSS}(\mathrm{mg} / \mathrm{L})$ & 430 \\
\hline $\mathrm{NH}_{4}-\mathrm{N}(\mathrm{mg} / \mathrm{L})$ & 3.2 \\
\hline Free-Cl $(\mathrm{mg} / \mathrm{L})$ & $<0.3$ \\
\hline Total $\mathrm{Cr}(\mathrm{mg} / \mathrm{L})$ & $<0.5$ \\
\hline Sulphide $(\mathrm{mg} / \mathrm{L})$ & $<2$ \\
\hline Sulphite $(\mathrm{mg} / \mathrm{L})$ & $<1$ \\
\hline Phenol $(\mathrm{mg} / \mathrm{L})$ & $<1$ \\
\hline $\mathrm{pH}$ & $11-12$ \\
\hline \hline
\end{tabular}




\section{APPENDIX C}

\section{SAMPLE WORKING SHEETS}

These working sheets were derived from Microsoft Excel 2007. 


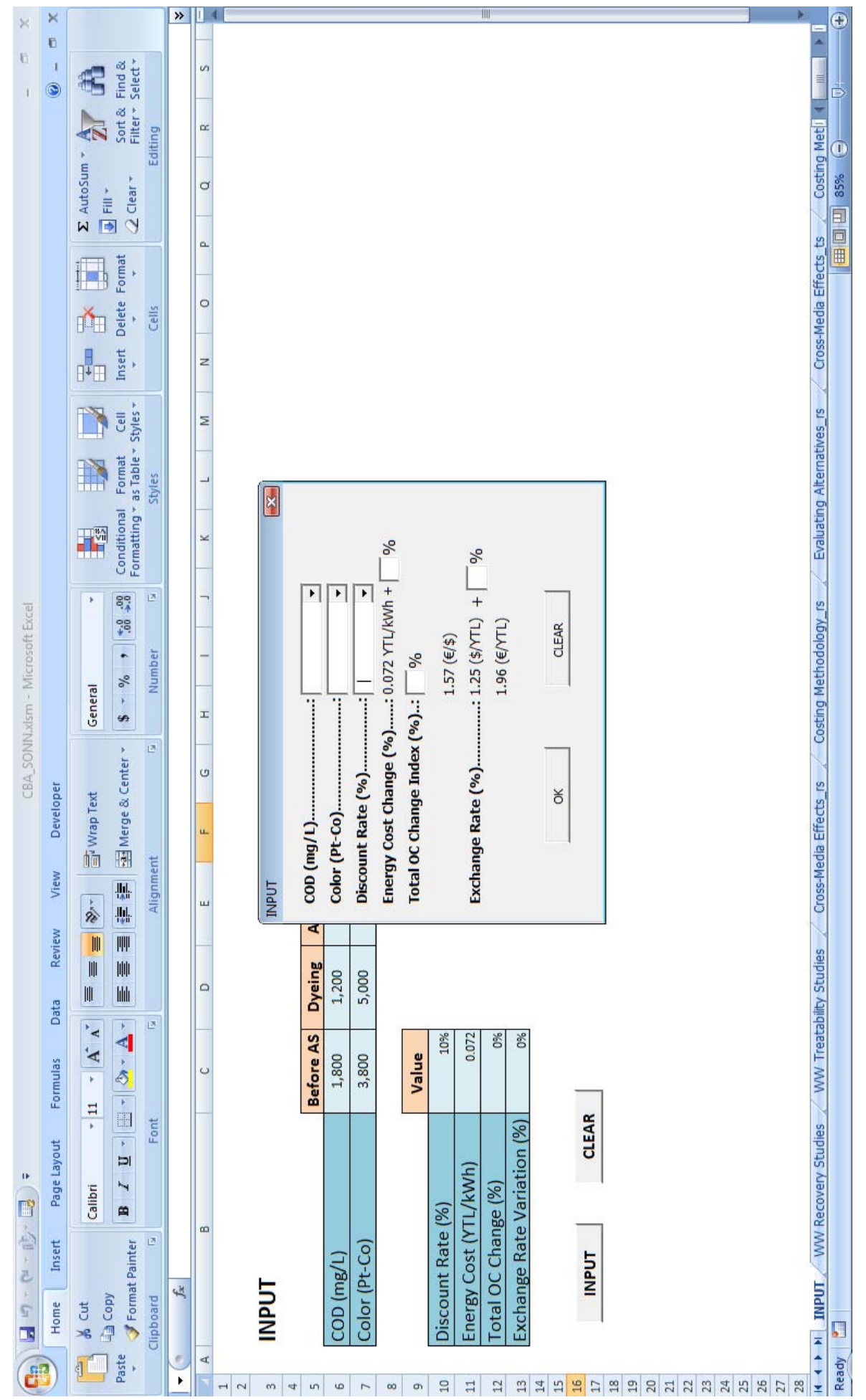

Figure C.1. Input page for sensitivity analysis 


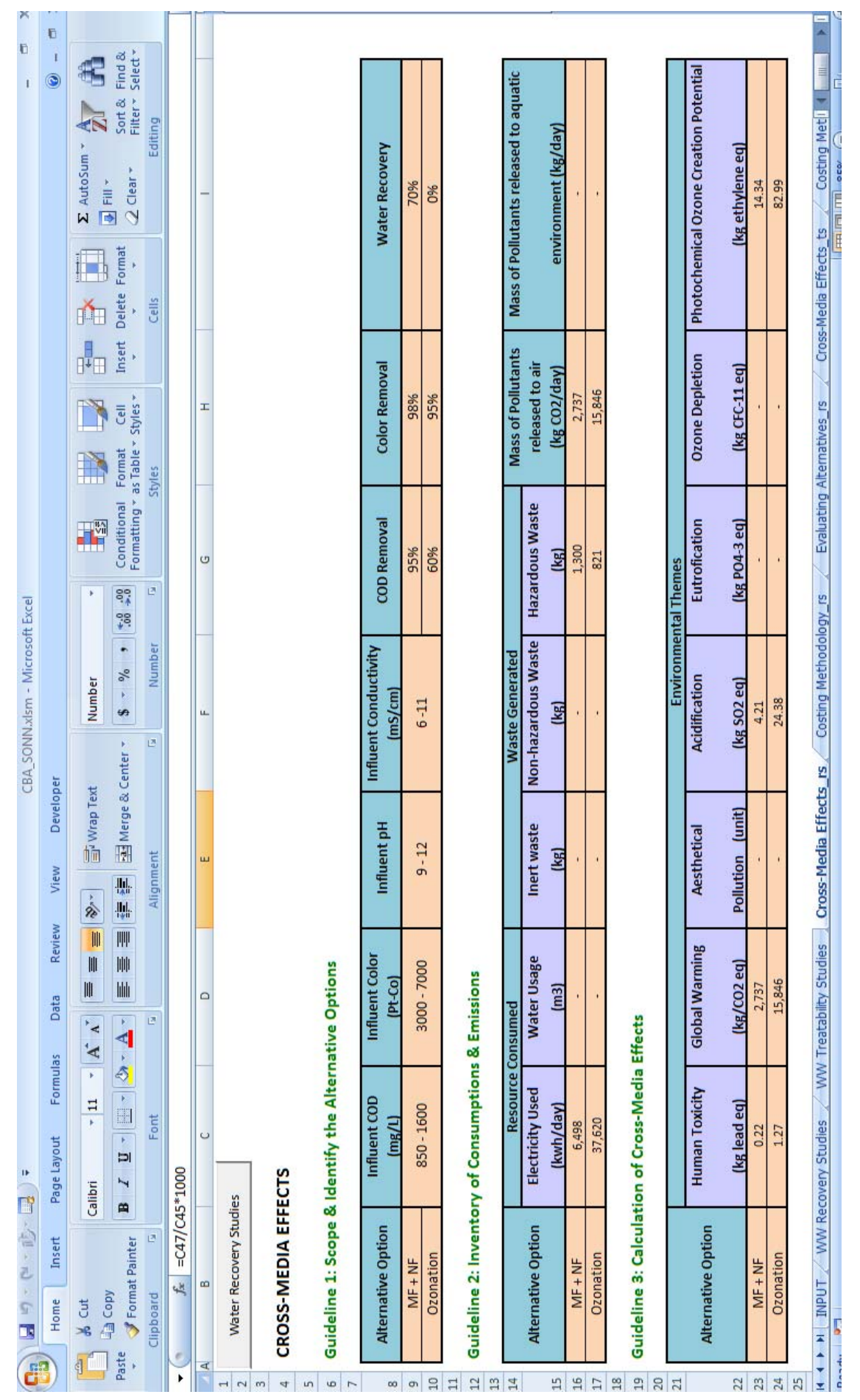

Figure C.2. Working sheet of cross-media effect assessment for water recovery studies 


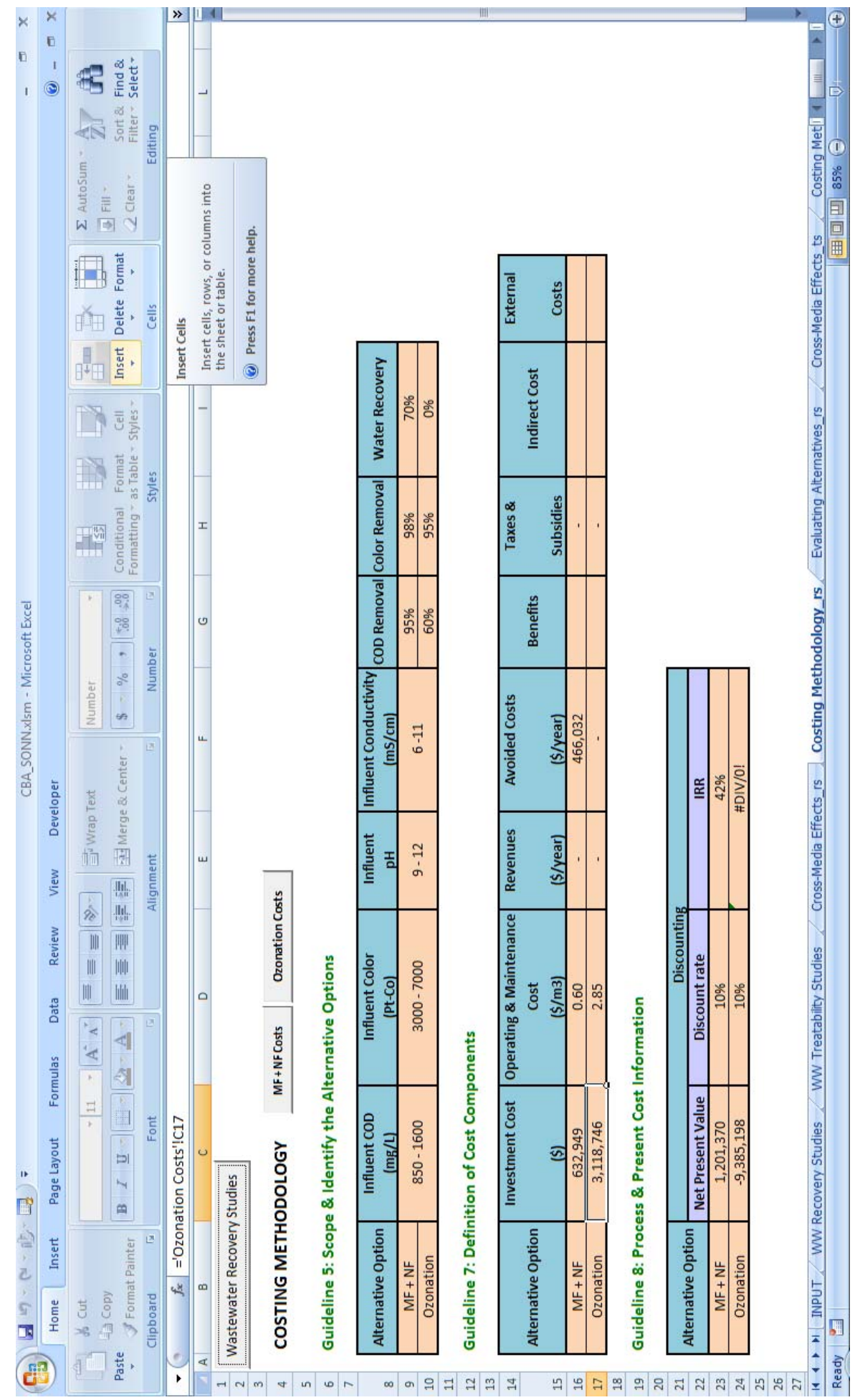

Figure C.3. Working sheet of financial analysis for water recovery studies 


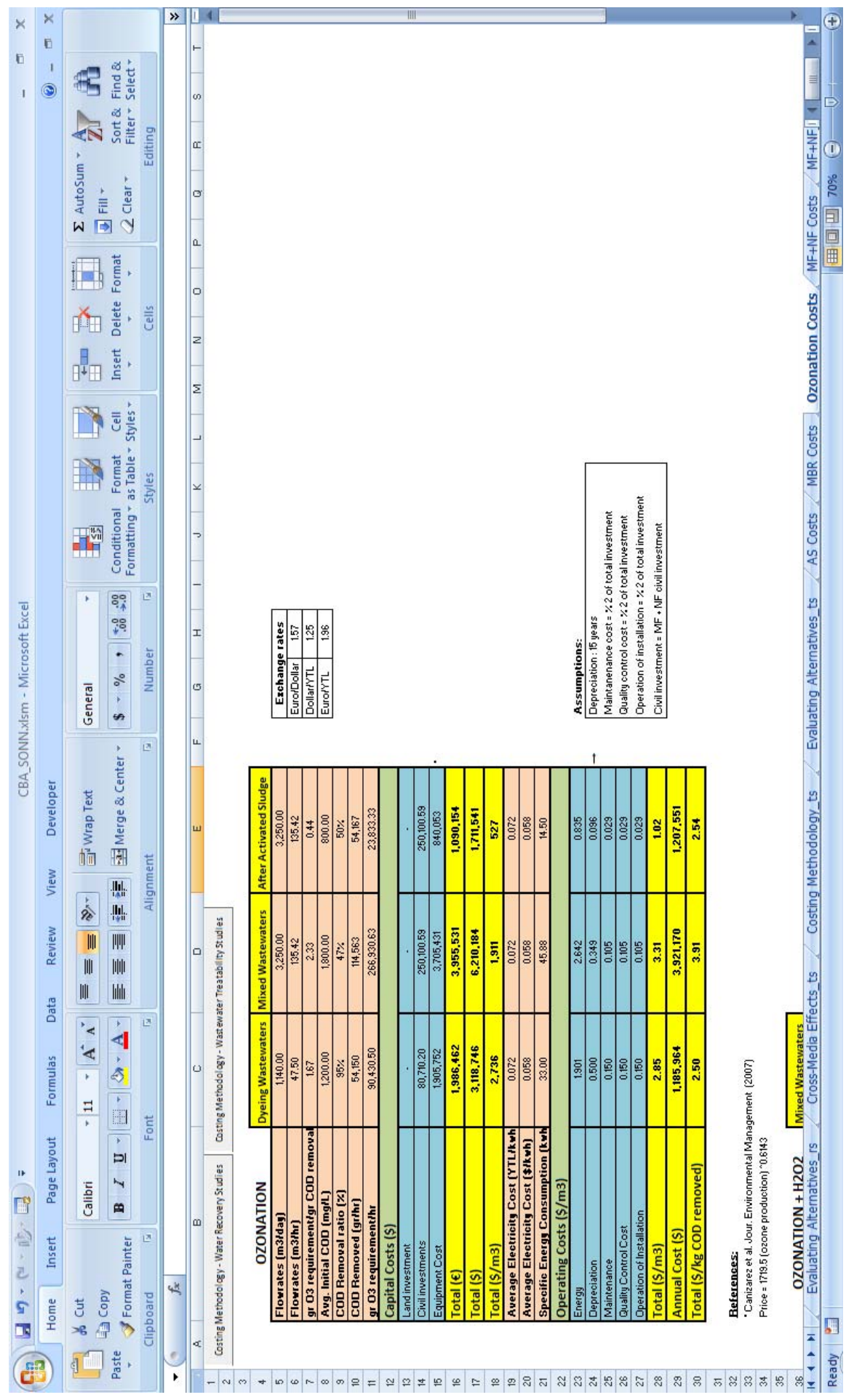

Figure C.4. Working sheet for ozonation cost calculations 


\section{APPENDIX D}

\section{SENSITIVITY DIAGRAMS}

This appendix provides the sensitivity diagrams for each of the water recovery and wastewater treatability alternatives. 

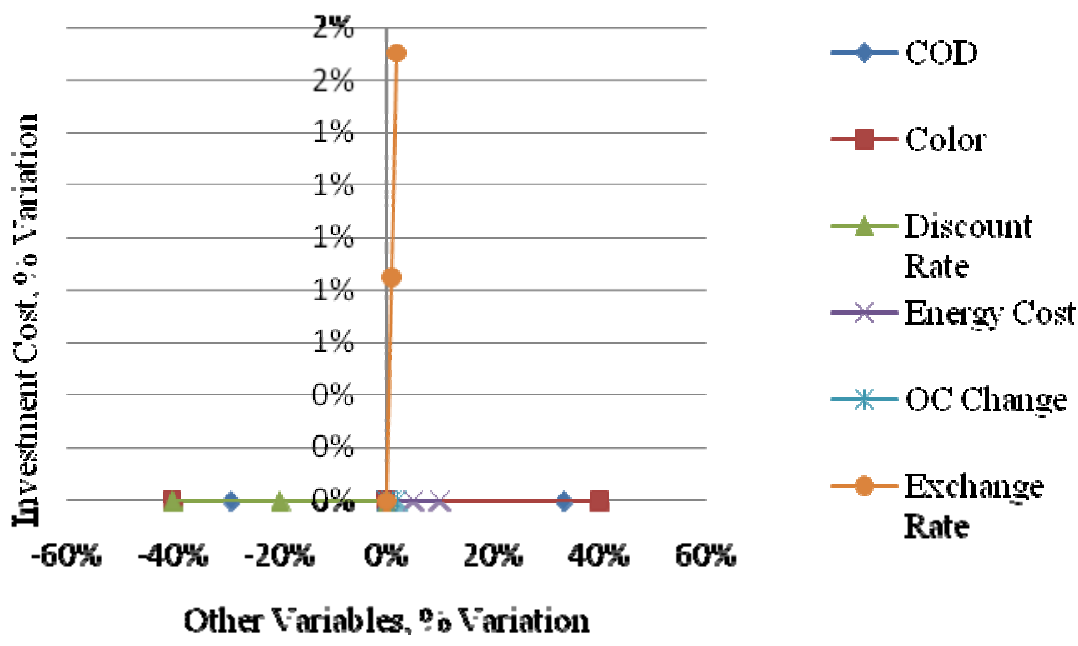

Figure D.1. Investment cost sensitivity diagram for MF + NF alternative applied in water recovery studies
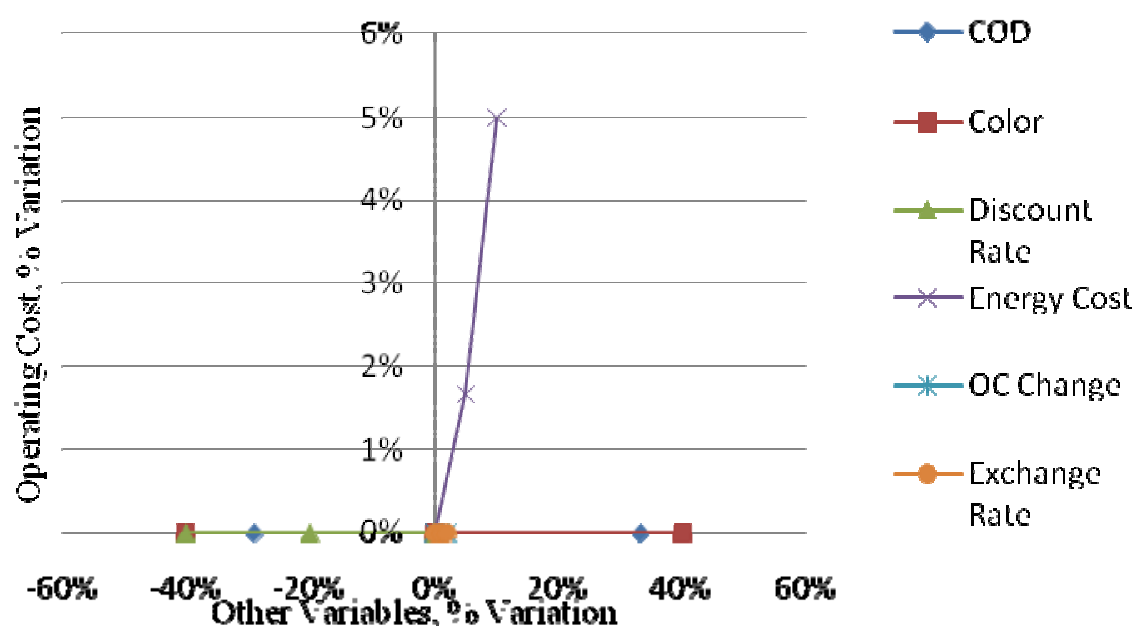

Figure D.2. Operating cost sensitivity diagram for $\mathrm{MF}+\mathrm{NF}$ alternative applied in water recovery studies 

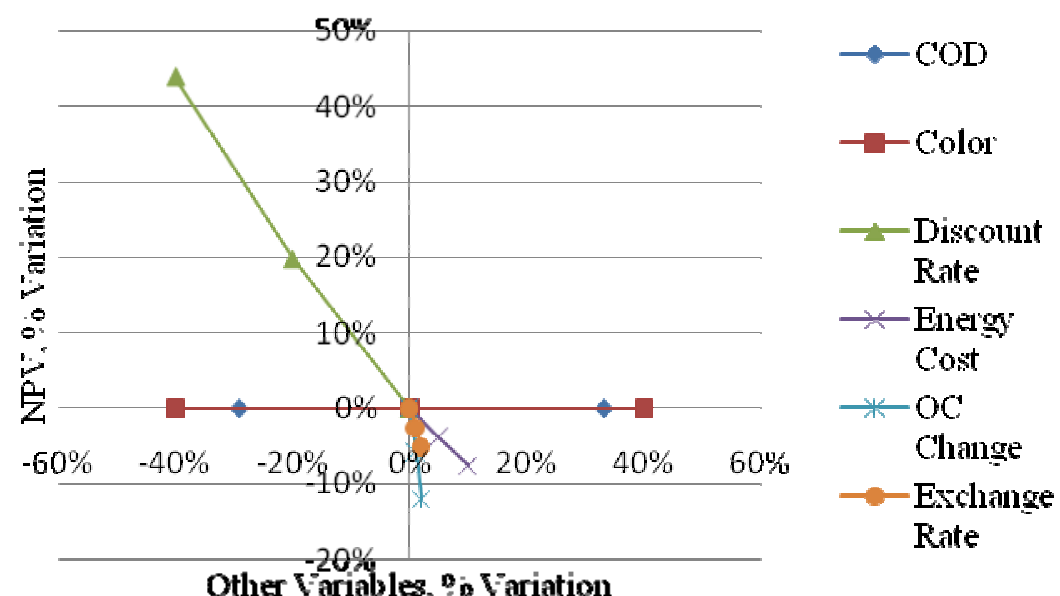

Figure D.3. NPV sensitivity diagram for MF + NF alternative applied in water recovery studies
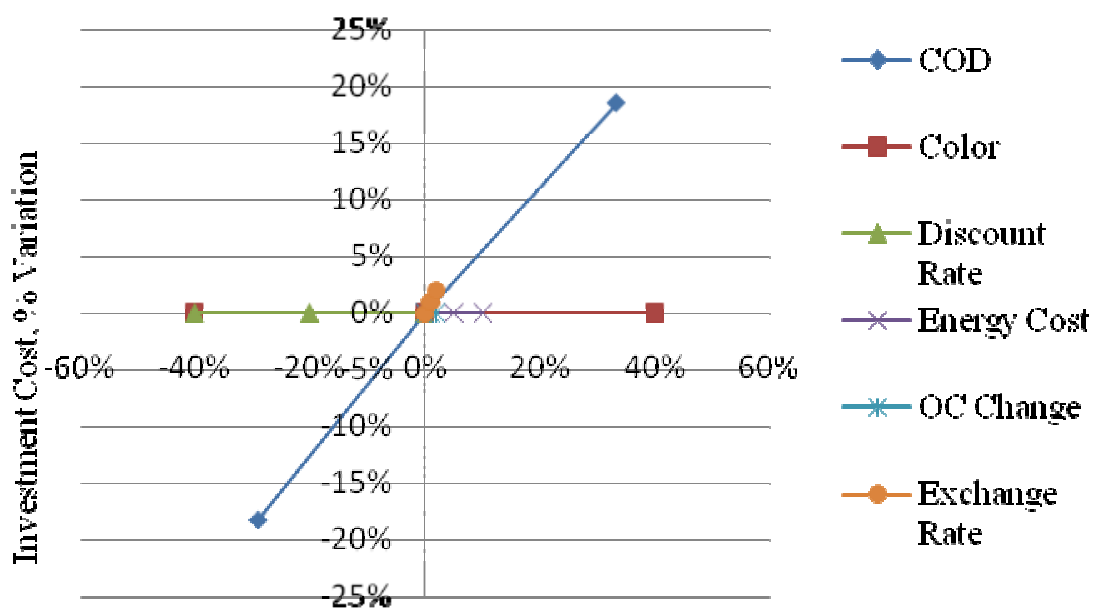

Other Variables, : : Variation

Figure D.4. Investment cost sensitivity diagram for ozonation alternative applied in water recovery studies 


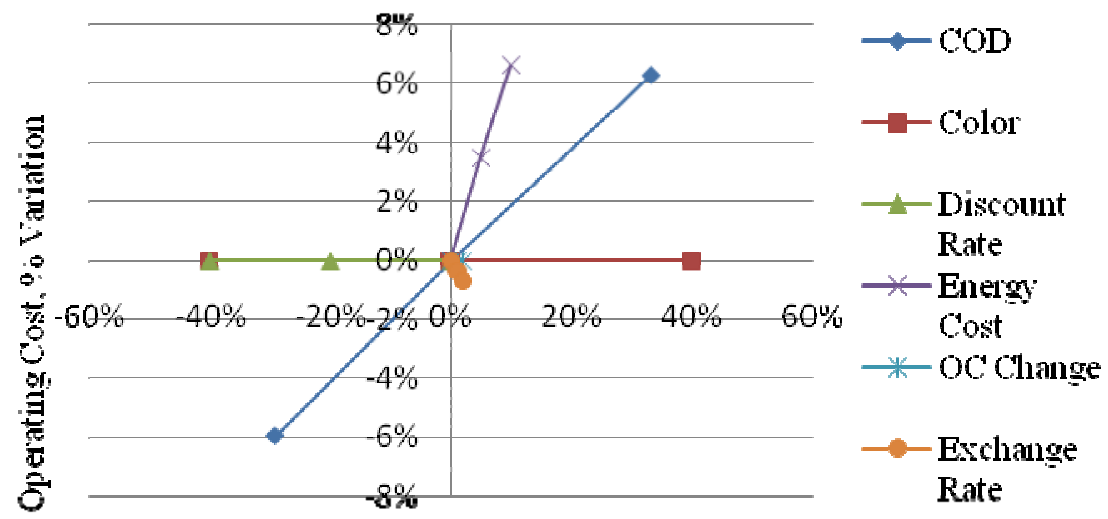

Other Variables, : Variation

Figure D.5. Operating cost sensitivity diagram for ozonation alternative applied in water recovery studies

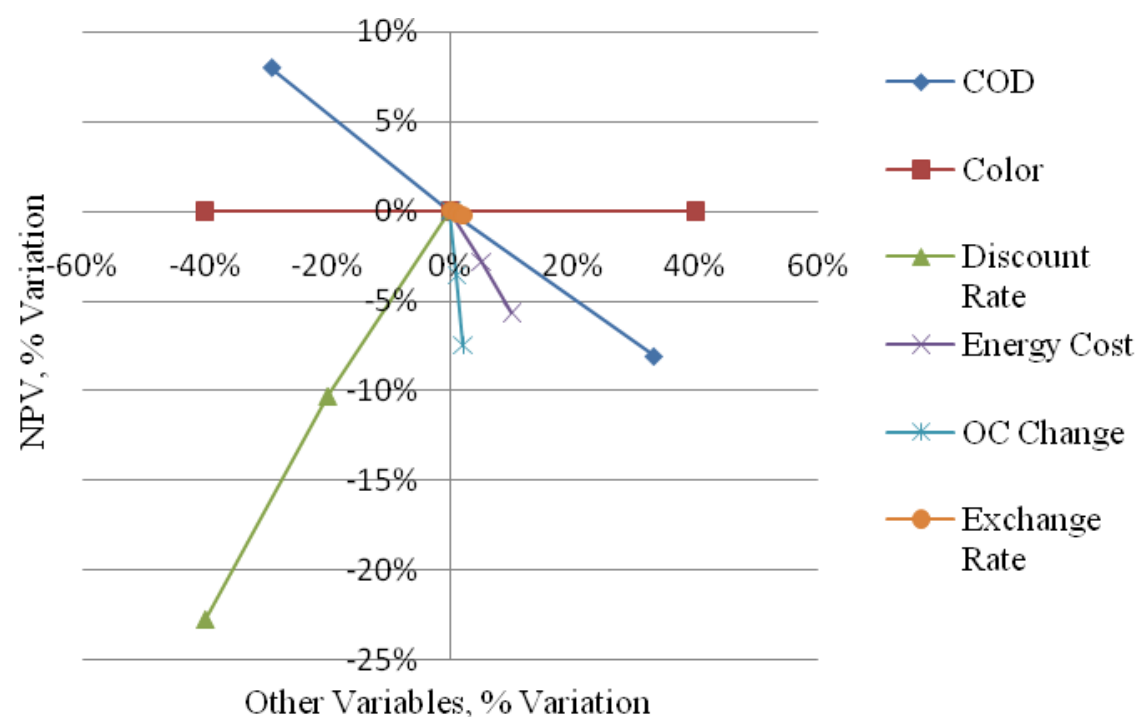

Figure D.6. NPV sensitivity diagram for ozonation alternative applied in water recovery studies 


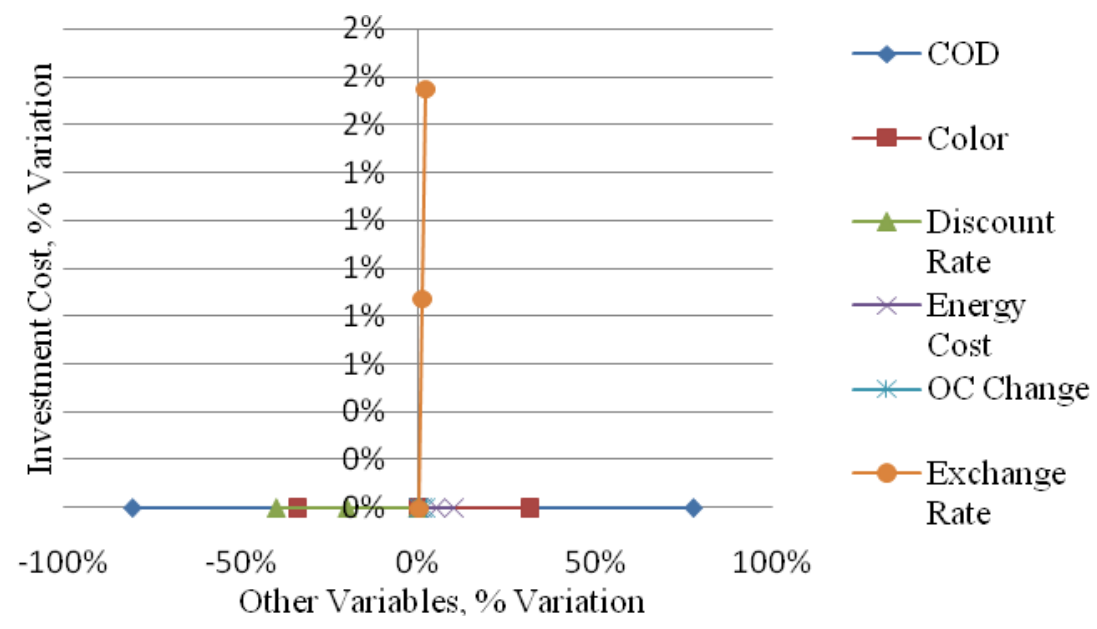

Figure D.7. Investment cost sensitivity diagram for the AS $+\mathrm{MF}+\mathrm{NF}$ alternative applied in wastewater treatability studies

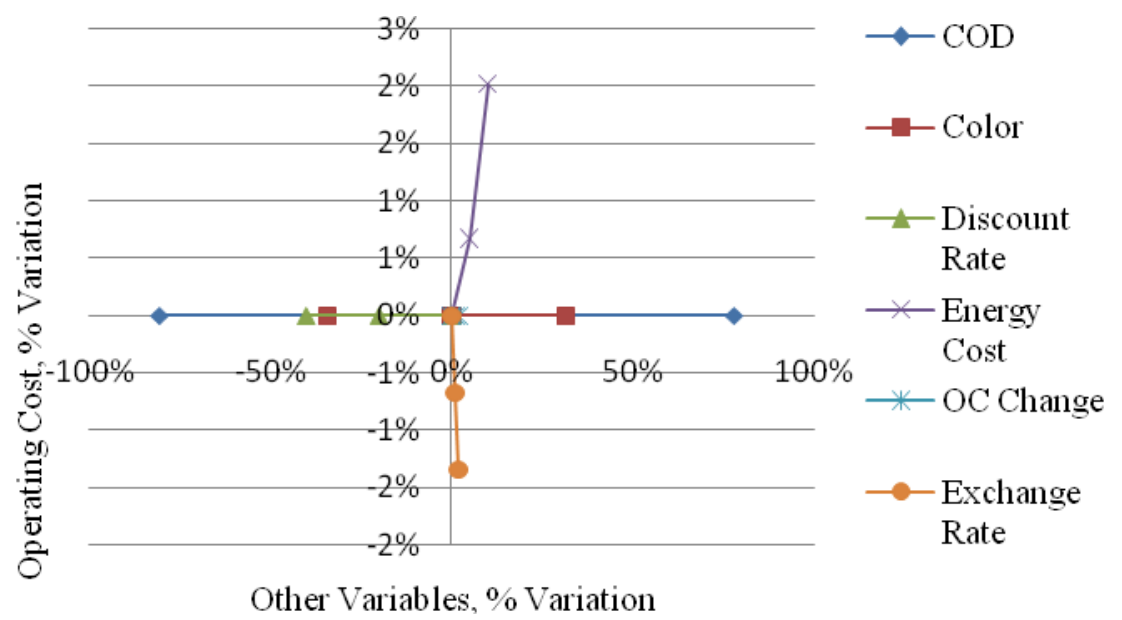

Figure D.8. Operating cost sensitivity diagram for the AS $+\mathrm{MF}+\mathrm{NF}$ alternative applied in wastewater treatability studies 


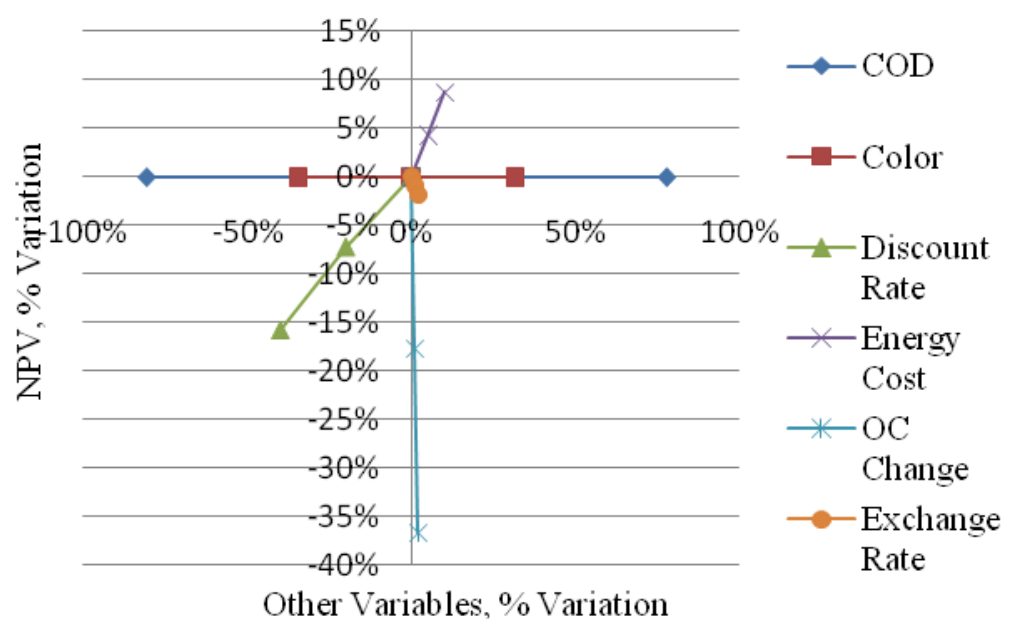

Figure D.9. NPV sensitivity diagram for the AS $+\mathrm{MF}+\mathrm{NF}$ alternative applied in wastewater treatability studies

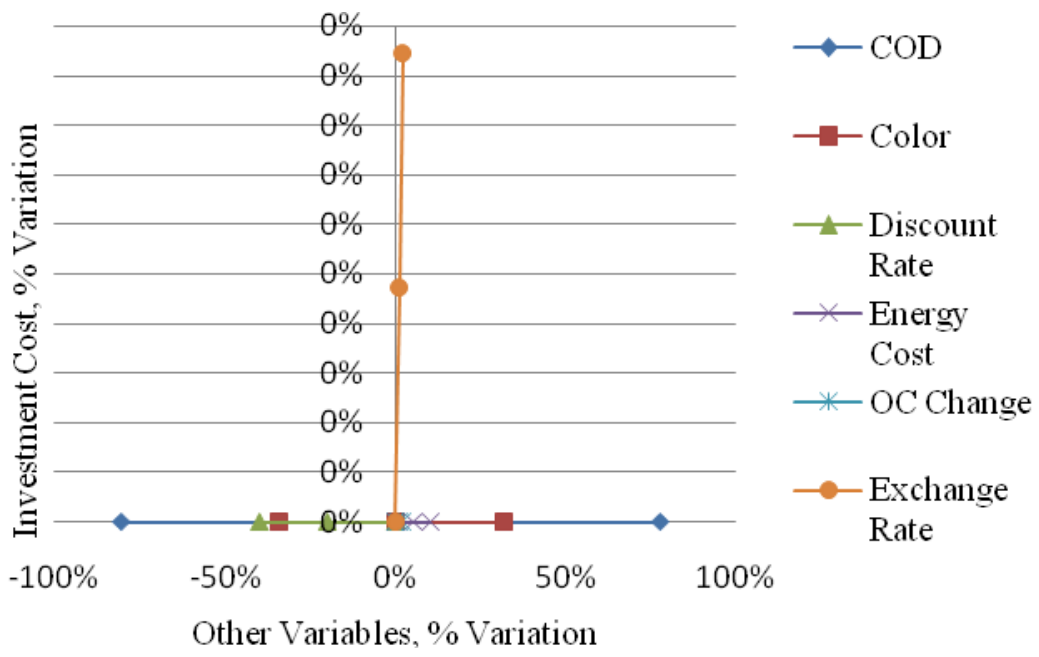

Figure D.10. Investment cost sensitivity diagram for the MBR alternative applied in wastewater treatability studies 


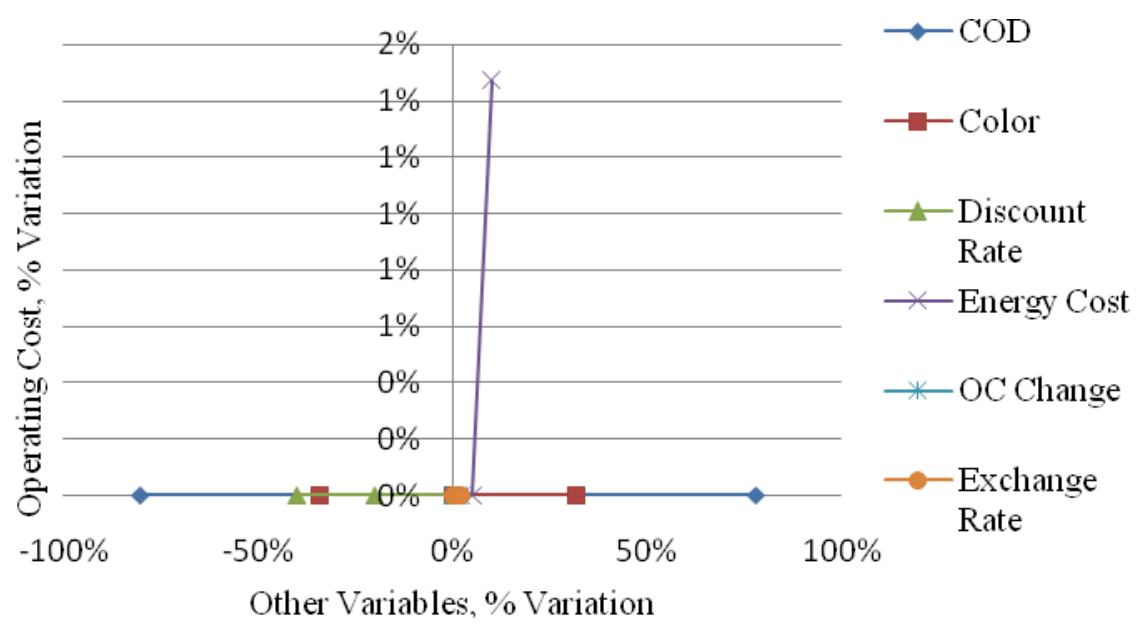

Figure D.11. Operating cost sensitivity diagram for the MBR alternative applied in wastewater treatability studies

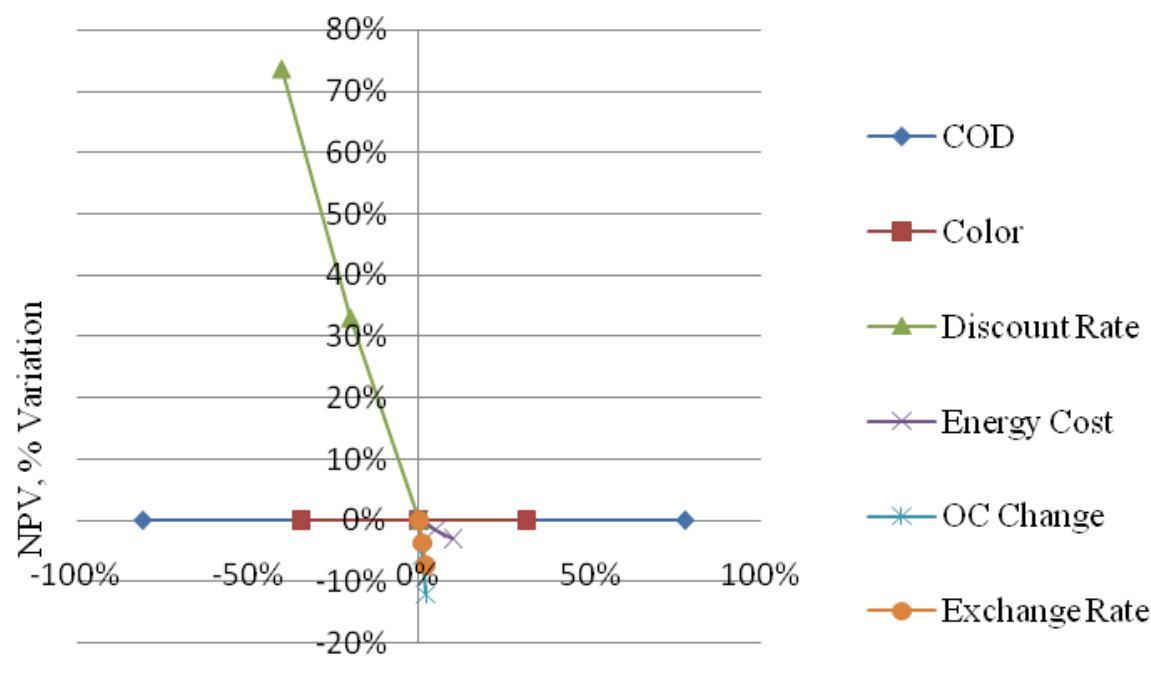

Other Variables, \% Variation

Figure D.12. NPV sensitivity diagram for the MBR alternative applied in wastewater treatability studies 


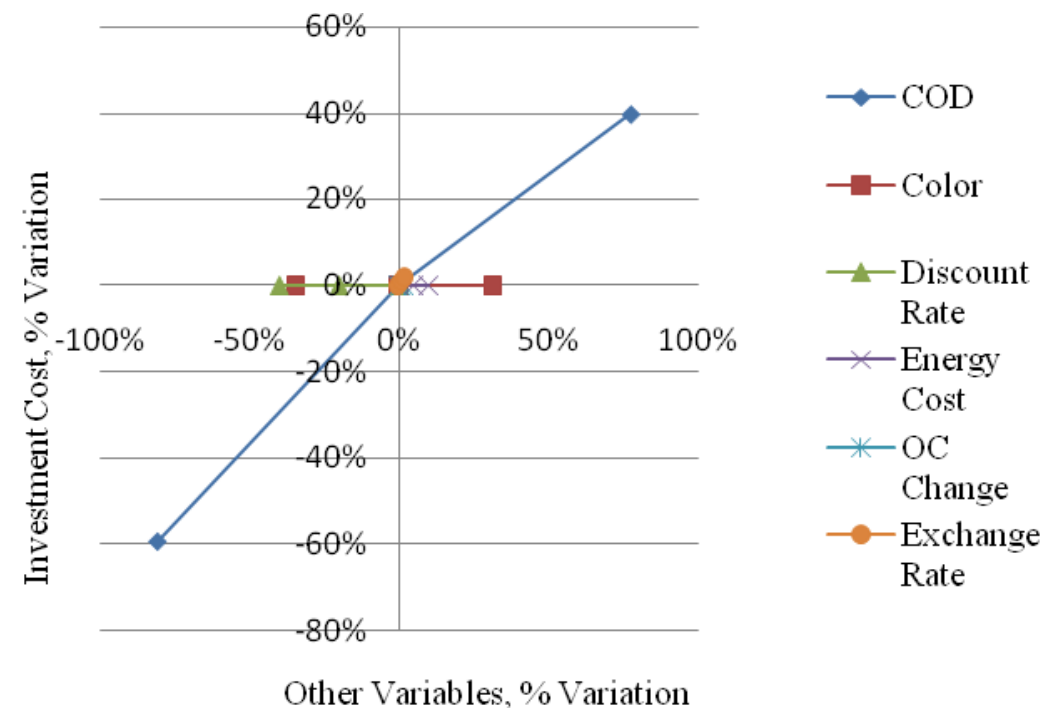

Figure D.13. Investment cost sensitivity diagram for the ozonation + AS alternative applied in wastewater treatability studies

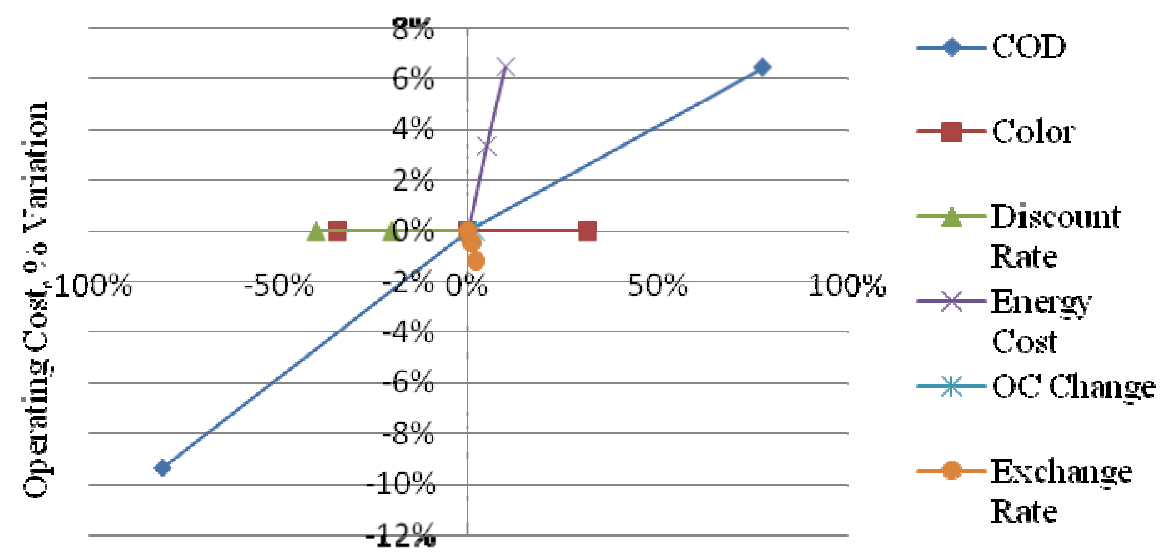

Other Variables, "s Variation

Figure D.14. Operating cost sensitivity diagram for the ozonation + AS alternative applied in wastewater treatability studies 

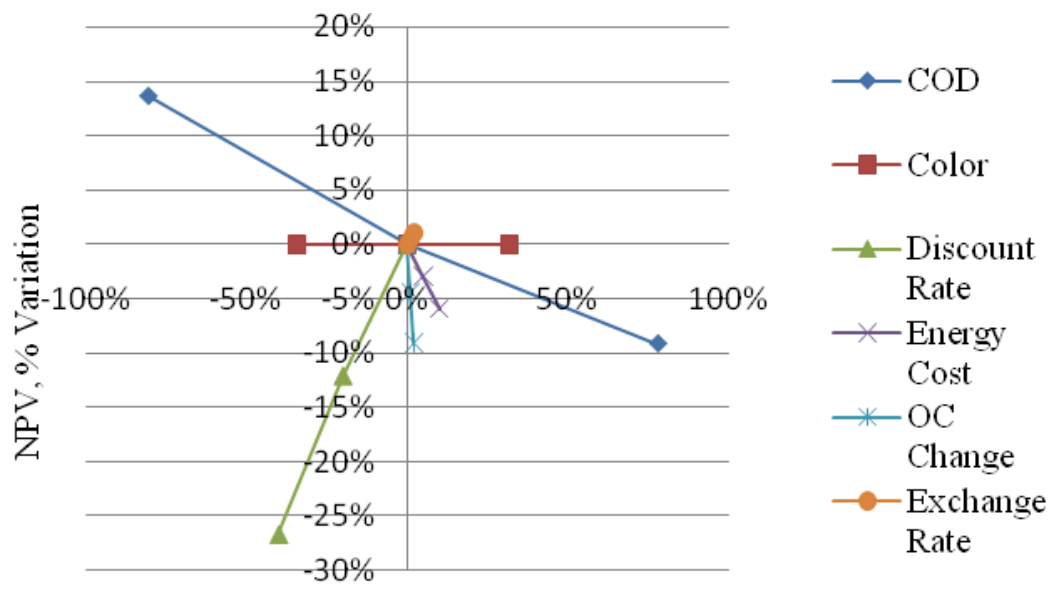

Other Variables, \% Variation

Figure D.15. NPV sensitivity diagram for the ozonation + AS alternative applied in wastewater treatability studies

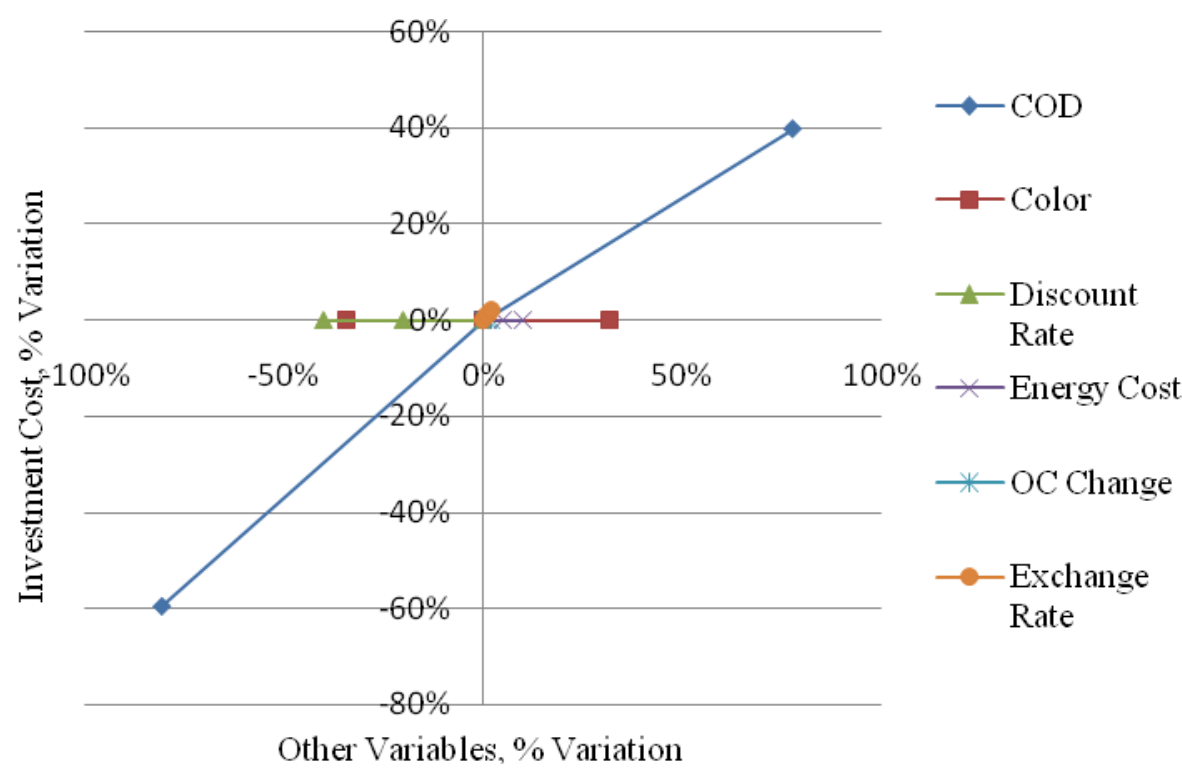

Figure D.16. Investment cost sensitivity diagram for the peroxone + AS alternative applied in wastewater treatability studies 


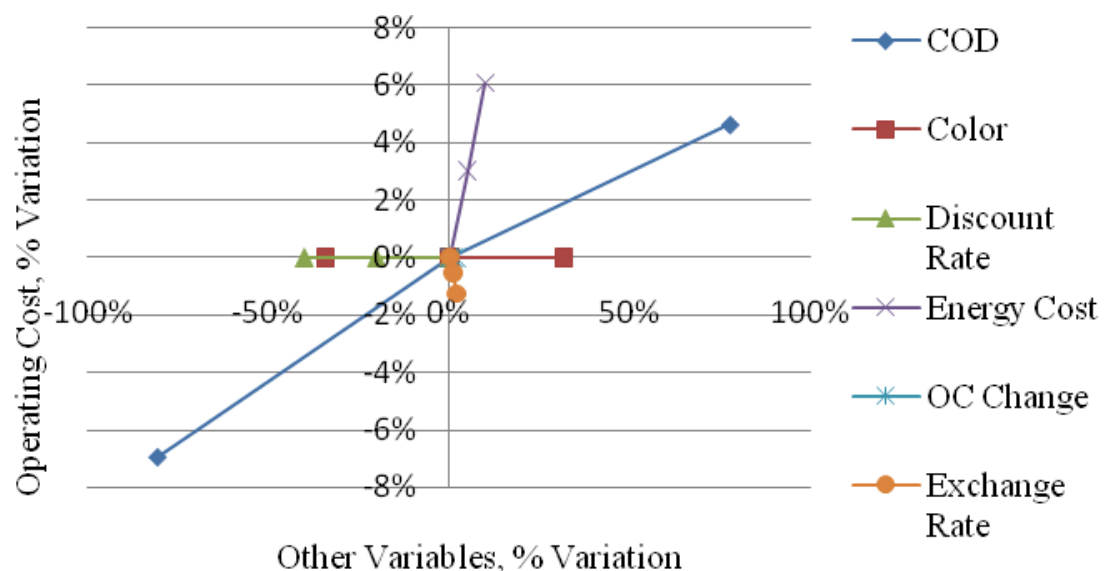

Figure D.17. Operating cost sensitivity diagram for the peroxone + AS alternative applied in wastewater treatability studies
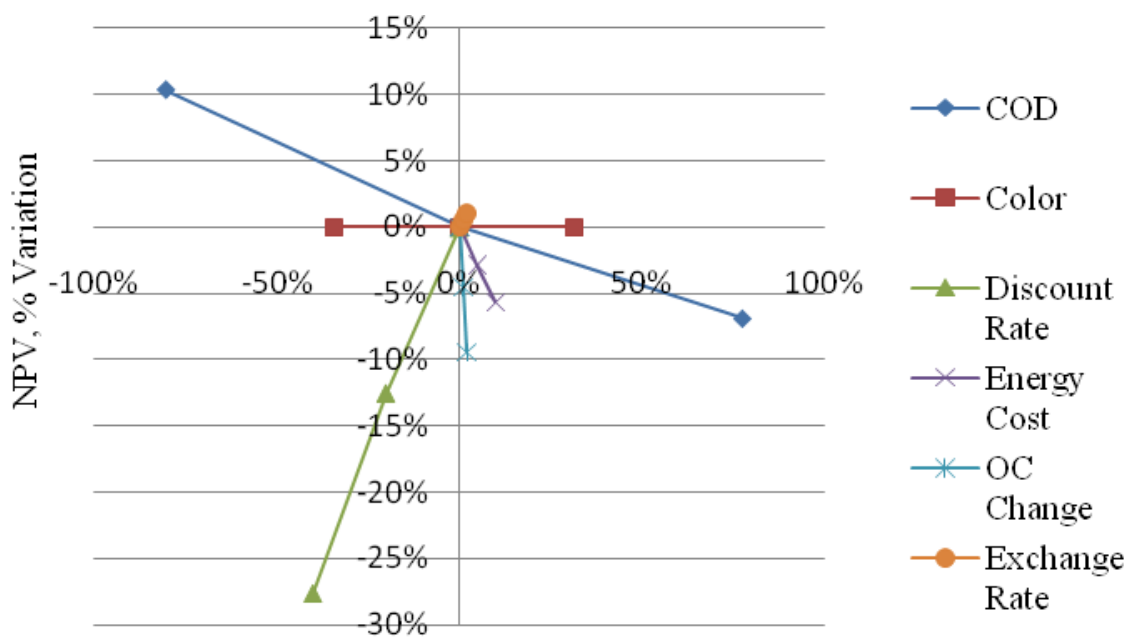

Other Variables, \% Variation

Figure D.18. NPV sensitivity diagram for the peroxone + AS alternative applied in wastewater treatability studies 


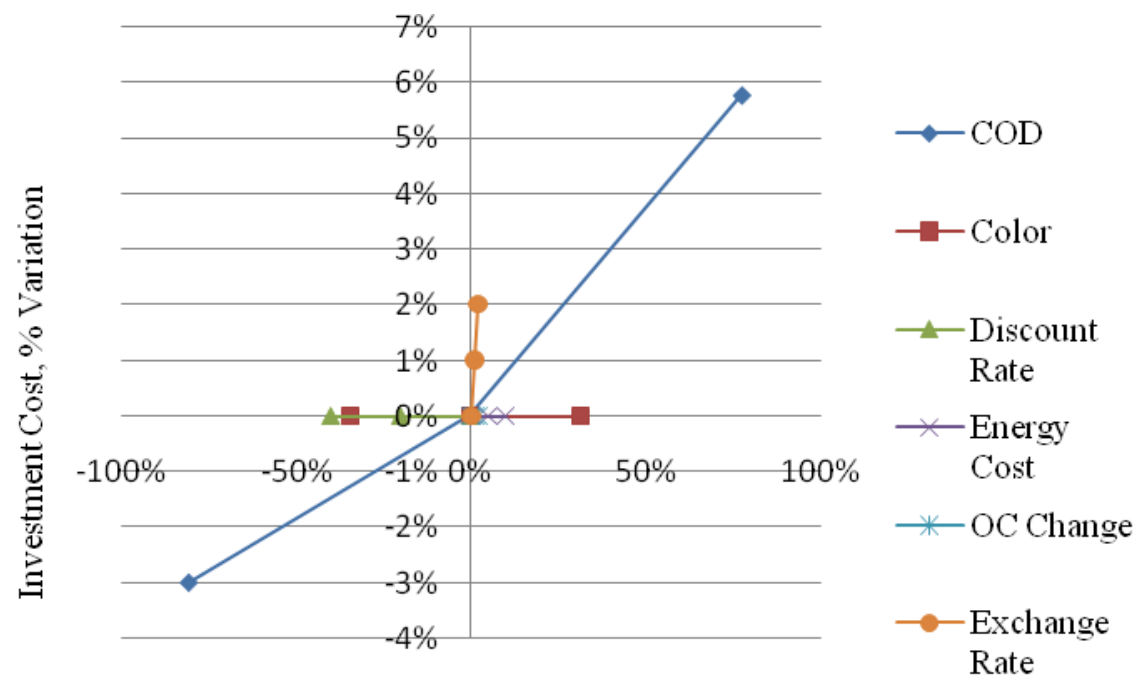

Other Variables, \% Variation

Figure D.19. Investment cost sensitivity diagram for the post ozonation alternative applied in wastewater treatability studies

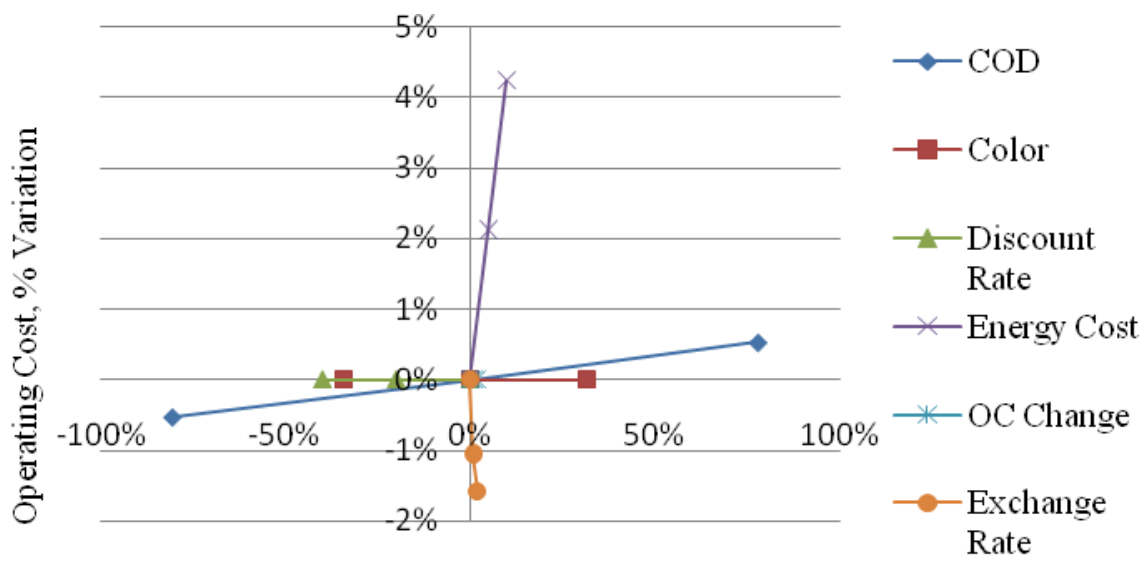

Other Variables, \% Variation

Figure D.20. Operating cost sensitivity diagram for the post ozonation alternative applied in wastewater treatability studies 


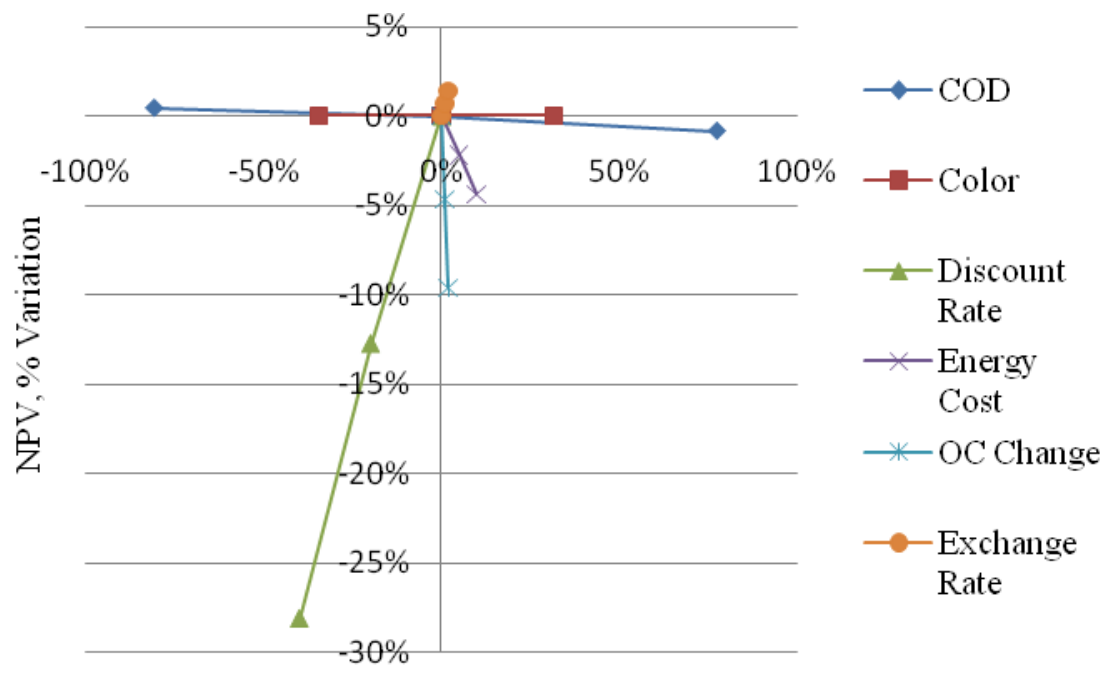

Other Variables, \% Variation

Figure D.21. NPV sensitivity diagram for the post ozonation alternative applied in wastewater treatability studies 


\section{APPENDIX E}

\section{SENSITIVITY ANALYSIS RESULTS}

In the following tables, the variations of the investment costs, operating costs, and NPV values according to the change in the critical variables are given as a result of sensitivity analyses performed both for water recovery studies and wastewater treatability studies. 
Table E.1. Changes in costs when critical variables change for water recovery alternatives

\begin{tabular}{|c|c|c|c|c|c|}
\hline $\begin{array}{l}\text { Alternative } \\
\text { options }\end{array}$ & $\begin{array}{c}\text { Critical } \\
\text { Variable }\end{array}$ & $\begin{array}{c}\text { Change in } \\
\text { variables }\end{array}$ & $\begin{array}{c}\text { Investment } \\
\text { cost } \\
\text { change }\end{array}$ & $\begin{array}{l}\text { Operating } \\
\text { cost change }\end{array}$ & $\begin{array}{c}\text { NPV } \\
\text { Change }\end{array}$ \\
\hline \multirow{18}{*}{$\mathrm{MF}+\mathrm{NF}$} & \multirow{3}{*}{ COD } & $33 \%$ & $0 \%$ & $0 \%$ & $0 \%$ \\
\hline & & $0 \%$ & $0 \%$ & $0 \%$ & $0 \%$ \\
\hline & & $-29 \%$ & $0 \%$ & $0 \%$ & $0 \%$ \\
\hline & \multirow{3}{*}{ Color } & $40 \%$ & $0 \%$ & $0 \%$ & $0 \%$ \\
\hline & & $0 \%$ & $0 \%$ & $0 \%$ & $0 \%$ \\
\hline & & $-40 \%$ & $0 \%$ & $0 \%$ & $0 \%$ \\
\hline & \multirow{3}{*}{$\begin{array}{l}\text { Discount } \\
\text { rate }\end{array}$} & $-40 \%$ & $0 \%$ & $0 \%$ & $44 \%$ \\
\hline & & $-20 \%$ & $0 \%$ & $0 \%$ & $20 \%$ \\
\hline & & $0 \%$ & $0 \%$ & $0 \%$ & $0 \%$ \\
\hline & \multirow{3}{*}{$\begin{array}{l}\text { Energy } \\
\text { cost }\end{array}$} & $0 \%$ & $0 \%$ & $0 \%$ & $0 \%$ \\
\hline & & $5 \%$ & $0 \%$ & $2 \%$ & $-4 \%$ \\
\hline & & $10 \%$ & $0 \%$ & $5 \%$ & $-8 \%$ \\
\hline & \multirow{3}{*}{$\begin{array}{l}\text { Operating } \\
\text { cost index }\end{array}$} & $0 \%$ & $0 \%$ & $0 \%$ & $0 \%$ \\
\hline & & $1 \%$ & $0 \%$ & $0 \%$ & $-6 \%$ \\
\hline & & $2 \%$ & $0 \%$ & $0 \%$ & $-12 \%$ \\
\hline & \multirow{3}{*}{$\begin{array}{l}\text { Exchange } \\
\text { rate } \\
\text { variation }\end{array}$} & $0 \%$ & $0 \%$ & $0 \%$ & $0 \%$ \\
\hline & & $1 \%$ & $1 \%$ & $0 \%$ & $-3 \%$ \\
\hline & & $2 \%$ & $2 \%$ & $0 \%$ & $-5 \%$ \\
\hline \multirow{18}{*}{ Ozonation } & \multirow{3}{*}{ COD } & $33 \%$ & $19 \%$ & $6 \%$ & $\begin{array}{c}-8 \% \\
\end{array}$ \\
\hline & & $0 \%$ & $0 \%$ & $0 \%$ & $0 \%$ \\
\hline & & $-29 \%$ & $-18 \%$ & $-6 \%$ & $8 \%$ \\
\hline & \multirow{3}{*}{ Color } & $40 \%$ & $0 \%$ & $0 \%$ & $0 \%$ \\
\hline & & $0 \%$ & $0 \%$ & $0 \%$ & $0 \%$ \\
\hline & & $-40 \%$ & $0 \%$ & $0 \%$ & $0 \%$ \\
\hline & \multirow{3}{*}{$\begin{array}{l}\text { Discount } \\
\text { rate }\end{array}$} & $-40 \%$ & $0 \%$ & $0 \%$ & $-23 \%$ \\
\hline & & $-20 \%$ & $0 \%$ & $0 \%$ & $-10 \%$ \\
\hline & & $0 \%$ & $0 \%$ & $0 \%$ & $0 \%$ \\
\hline & \multirow{3}{*}{$\begin{array}{c}\text { Energy } \\
\text { cost }\end{array}$} & $10 \%$ & $0 \%$ & $7 \%$ & $-6 \%$ \\
\hline & & $5 \%$ & $0 \%$ & $4 \%$ & $-3 \%$ \\
\hline & & $0 \%$ & $0 \%$ & $0 \%$ & $0 \%$ \\
\hline & \multirow{3}{*}{$\begin{array}{l}\text { Operating } \\
\text { cost index }\end{array}$} & $2 \%$ & $0 \%$ & $0 \%$ & $-7 \%$ \\
\hline & & $1 \%$ & $0 \%$ & $0 \%$ & $-4 \%$ \\
\hline & & $0 \%$ & $0 \%$ & $0 \%$ & $0 \%$ \\
\hline & \multirow{3}{*}{$\begin{array}{l}\text { Exchange } \\
\text { rate } \\
\text { variation }\end{array}$} & $0 \%$ & $0 \%$ & $0 \%$ & $0 \%$ \\
\hline & & $1 \%$ & $1 \%$ & $0 \%$ & $0 \%$ \\
\hline & & $2 \%$ & $2 \%$ & $-1 \%$ & $0 \%$ \\
\hline
\end{tabular}


Table E.2. Changes in costs when critical variables change for wastewater treatability alternatives

\begin{tabular}{|c|c|c|c|c|c|}
\hline $\begin{array}{l}\text { Alternative } \\
\text { options }\end{array}$ & $\begin{array}{l}\text { Critical } \\
\text { Variable }\end{array}$ & $\begin{array}{l}\text { Change in } \\
\text { variables }\end{array}$ & $\begin{array}{c}\text { Investment } \\
\text { cost } \\
\text { change } \\
\end{array}$ & $\begin{array}{l}\text { Operating } \\
\text { cost change }\end{array}$ & $\begin{array}{l}\text { NPV } \\
\text { Change }\end{array}$ \\
\hline \multirow{18}{*}{$\begin{array}{c}\mathrm{AS}+\mathrm{MF}+ \\
\mathrm{NF}\end{array}$} & \multirow{3}{*}{ COD } & $78 \%$ & $0 \%$ & $0 \%$ & $0 \%$ \\
\hline & & $0 \%$ & $0 \%$ & $0 \%$ & $0 \%$ \\
\hline & & $-81 \%$ & $0 \%$ & $0 \%$ & $0 \%$ \\
\hline & \multirow{3}{*}{ Color } & $32 \%$ & $0 \%$ & $0 \%$ & $0 \%$ \\
\hline & & $0 \%$ & $0 \%$ & $0 \%$ & $0 \%$ \\
\hline & & $-34 \%$ & $0 \%$ & $0 \%$ & $0 \%$ \\
\hline & \multirow{3}{*}{$\begin{array}{l}\text { Discount } \\
\text { rate }\end{array}$} & $-40 \%$ & $0 \%$ & $0 \%$ & $-16 \%$ \\
\hline & & $-20 \%$ & $0 \%$ & $0 \%$ & $-7 \%$ \\
\hline & & $0 \%$ & $0 \%$ & $0 \%$ & $0 \%$ \\
\hline & \multirow{3}{*}{$\begin{array}{l}\text { Energy } \\
\text { cost }\end{array}$} & $0 \%$ & $0 \%$ & $2 \%$ & $9 \%$ \\
\hline & & $5 \%$ & $0 \%$ & $1 \%$ & $4 \%$ \\
\hline & & $10 \%$ & $0 \%$ & $0 \%$ & $0 \%$ \\
\hline & \multirow{3}{*}{$\begin{array}{l}\text { Operating } \\
\text { cost index }\end{array}$} & $0 \%$ & $0 \%$ & $0 \%$ & $-37 \%$ \\
\hline & & $1 \%$ & $0 \%$ & $0 \%$ & $-18 \%$ \\
\hline & & $2 \%$ & $0 \%$ & $0 \%$ & $0 \%$ \\
\hline & \multirow{3}{*}{$\begin{array}{l}\text { Exchange } \\
\text { rate } \\
\text { variation }\end{array}$} & $0 \%$ & $0 \%$ & $0 \%$ & $0 \%$ \\
\hline & & $1 \%$ & $1 \%$ & $-1 \%$ & $-1 \%$ \\
\hline & & $2 \%$ & $2 \%$ & $-1 \%$ & $-2 \%$ \\
\hline \multirow{18}{*}{ MBR } & \multirow{3}{*}{ COD } & $78 \%$ & $0 \%$ & $0 \%$ & $0 \%$ \\
\hline & & $0 \%$ & $0 \%$ & $0 \%$ & $0 \%$ \\
\hline & & $-81 \%$ & $0 \%$ & $0 \%$ & $0 \%$ \\
\hline & \multirow{3}{*}{ Color } & $32 \%$ & $0 \%$ & $0 \%$ & $0 \%$ \\
\hline & & $0 \%$ & $0 \%$ & $0 \%$ & $0 \%$ \\
\hline & & $-34 \%$ & $0 \%$ & $0 \%$ & $0 \%$ \\
\hline & \multirow{3}{*}{$\begin{array}{l}\text { Discount } \\
\text { rate }\end{array}$} & $-40 \%$ & $0 \%$ & $0 \%$ & $73 \%$ \\
\hline & & $-20 \%$ & $0 \%$ & $0 \%$ & $33 \%$ \\
\hline & & $0 \%$ & $0 \%$ & $0 \%$ & $0 \%$ \\
\hline & \multirow{3}{*}{$\begin{array}{l}\text { Energy } \\
\text { cost }\end{array}$} & $10 \%$ & $0 \%$ & $1 \%$ & $-3 \%$ \\
\hline & & $5 \%$ & $0 \%$ & $0 \%$ & $-2 \%$ \\
\hline & & $0 \%$ & $0 \%$ & $0 \%$ & $0 \%$ \\
\hline & \multirow{3}{*}{$\begin{array}{l}\text { Operating } \\
\text { cost index }\end{array}$} & $0 \%$ & $0 \%$ & $0 \%$ & $-12 \%$ \\
\hline & & $1 \%$ & $0 \%$ & $0 \%$ & $-6 \%$ \\
\hline & & $2 \%$ & $0 \%$ & $0 \%$ & $0 \%$ \\
\hline & \multirow{3}{*}{$\begin{array}{l}\text { Exchange } \\
\text { rate } \\
\text { variation }\end{array}$} & $\begin{array}{c}0 \% \\
\end{array}$ & $0 \%$ & $0 \%$ & $0 \%$ \\
\hline & & $1 \%$ & $0 \%$ & $0 \%$ & $-4 \%$ \\
\hline & & $2 \%$ & $0 \%$ & $0 \%$ & $-7 \%$ \\
\hline
\end{tabular}


Table E.2. (Continued)

\begin{tabular}{|c|c|c|c|c|c|}
\hline $\begin{array}{l}\text { Alternative } \\
\text { options }\end{array}$ & $\begin{array}{c}\text { Critical } \\
\text { Variable }\end{array}$ & $\begin{array}{l}\text { Change in } \\
\text { variables }\end{array}$ & $\begin{array}{c}\begin{array}{c}\text { Investment } \\
\text { cost } \\
\text { change }\end{array} \\
\end{array}$ & $\begin{array}{c}\text { Operating } \\
\text { cost } \\
\text { change } \\
\end{array}$ & $\begin{array}{c}\text { NPV } \\
\text { Change }\end{array}$ \\
\hline \multirow{18}{*}{$\begin{array}{c}\text { Ozonation }+ \\
\text { AS }\end{array}$} & \multirow{3}{*}{ COD } & $78 \%$ & $40 \%$ & $6 \%$ & $-9 \%$ \\
\hline & & $0 \%$ & $0 \%$ & $0 \%$ & $0 \%$ \\
\hline & & $-81 \%$ & $-59 \%$ & $-9 \%$ & $14 \%$ \\
\hline & \multirow{3}{*}{ Color } & $32 \%$ & $0 \%$ & $0 \%$ & $0 \%$ \\
\hline & & $0 \%$ & $0 \%$ & $0 \%$ & $0 \%$ \\
\hline & & $-34 \%$ & $0 \%$ & $0 \%$ & $0 \%$ \\
\hline & \multirow{3}{*}{$\begin{array}{l}\text { Discount } \\
\text { rate }\end{array}$} & $-40 \%$ & $0 \%$ & $0 \%$ & $\begin{array}{l}-27 \% \\
\end{array}$ \\
\hline & & $-20 \%$ & $0 \%$ & $0 \%$ & $-12 \%$ \\
\hline & & $0 \%$ & $0 \%$ & $0 \%$ & $0 \%$ \\
\hline & \multirow{3}{*}{$\begin{array}{c}\text { Energy } \\
\text { cost }\end{array}$} & $0 \%$ & $0 \%$ & $6 \%$ & $-6 \%$ \\
\hline & & $5 \%$ & $0 \%$ & $3 \%$ & $-3 \%$ \\
\hline & & $10 \%$ & $0 \%$ & $0 \%$ & $0 \%$ \\
\hline & \multirow{3}{*}{$\begin{array}{l}\text { Operating } \\
\text { cost index }\end{array}$} & $0 \%$ & $0 \%$ & $0 \%$ & $-9 \%$ \\
\hline & & $1 \%$ & $0 \%$ & $0 \%$ & $-4 \%$ \\
\hline & & $2 \%$ & $0 \%$ & $0 \%$ & $0 \%$ \\
\hline & \multirow{3}{*}{$\begin{array}{l}\text { Exchange } \\
\text { rate } \\
\text { variation }\end{array}$} & $0 \%$ & $0 \%$ & $0 \%$ & $0 \%$ \\
\hline & & $1 \%$ & $1 \%$ & $0 \%$ & $1 \%$ \\
\hline & & $2 \%$ & $2 \%$ & $-1 \%$ & $1 \%$ \\
\hline \multirow{18}{*}{$\begin{array}{l}\text { Ozonation }+ \\
\mathrm{H}_{2} \mathrm{O}_{2}+\mathrm{AS}\end{array}$} & \multirow{3}{*}{ COD } & $78 \%$ & $40 \%$ & $5 \%$ & $-7 \%$ \\
\hline & & $0 \%$ & $0 \%$ & $0 \%$ & $0 \%$ \\
\hline & & $-81 \%$ & $-59 \%$ & $-7 \%$ & $10 \%$ \\
\hline & \multirow{3}{*}{ Color } & $32 \%$ & $0 \%$ & $0 \%$ & $0 \%$ \\
\hline & & $0 \%$ & $0 \%$ & $0 \%$ & $0 \%$ \\
\hline & & $-34 \%$ & $0 \%$ & $0 \%$ & $0 \%$ \\
\hline & \multirow{3}{*}{$\begin{array}{l}\text { Discount } \\
\text { rate }\end{array}$} & $-40 \%$ & $0 \%$ & $0 \%$ & $-28 \%$ \\
\hline & & $-20 \%$ & $0 \%$ & $0 \%$ & $-13 \%$ \\
\hline & & $0 \%$ & $0 \%$ & $0 \%$ & $0 \%$ \\
\hline & \multirow{3}{*}{$\begin{array}{l}\text { Energy } \\
\text { cost }\end{array}$} & $10 \%$ & $0 \%$ & $6 \%$ & $-6 \%$ \\
\hline & & $5 \%$ & $0 \%$ & $3 \%$ & $-3 \%$ \\
\hline & & $0 \%$ & $0 \%$ & $0 \%$ & $0 \%$ \\
\hline & \multirow{3}{*}{$\begin{array}{l}\text { Operating } \\
\text { cost index }\end{array}$} & $0 \%$ & $0 \%$ & $0 \%$ & $-9 \%$ \\
\hline & & $1 \%$ & $0 \%$ & $0 \%$ & $-5 \%$ \\
\hline & & $2 \%$ & $0 \%$ & $0 \%$ & $0 \%$ \\
\hline & \multirow{3}{*}{$\begin{array}{c}\text { Exchange } \\
\text { rate } \\
\text { variation }\end{array}$} & $0 \%$ & $0 \%$ & $0 \%$ & $0 \%$ \\
\hline & & $1 \%$ & $1 \%$ & $-1 \%$ & $1 \%$ \\
\hline & & $2 \%$ & $2 \%$ & $-1 \%$ & $1 \%$ \\
\hline
\end{tabular}


Table E.2. (Continued)

\begin{tabular}{|c|c|c|c|c|c|}
\hline $\begin{array}{l}\text { Alternative } \\
\text { options }\end{array}$ & $\begin{array}{c}\text { Critical } \\
\text { Variable }\end{array}$ & $\begin{array}{c}\text { Change } \\
\text { in } \\
\text { variables }\end{array}$ & $\begin{array}{c}\text { Investment } \\
\text { cost } \\
\text { change }\end{array}$ & $\begin{array}{c}\text { Operating } \\
\text { cost } \\
\text { change }\end{array}$ & $\begin{array}{l}\text { NPV } \\
\text { Change }\end{array}$ \\
\hline \multirow{18}{*}{$\begin{array}{c}\mathrm{AS}+ \\
\text { Ozonation }\end{array}$} & \multirow{3}{*}{ COD } & $78 \%$ & $6 \%$ & $1 \%$ & $-1 \%$ \\
\hline & & $0 \%$ & $0 \%$ & $0 \%$ & $0 \%$ \\
\hline & & $-81 \%$ & $-3 \%$ & $-1 \%$ & $0 \%$ \\
\hline & \multirow{3}{*}{ Color } & $32 \%$ & $0 \%$ & $0 \%$ & $0 \%$ \\
\hline & & $0 \%$ & $0 \%$ & $0 \%$ & $0 \%$ \\
\hline & & $-34 \%$ & $0 \%$ & $0 \%$ & $0 \%$ \\
\hline & \multirow{3}{*}{$\begin{array}{l}\text { Discount } \\
\text { rate }\end{array}$} & $-40 \%$ & $0 \%$ & $0 \%$ & $-28 \%$ \\
\hline & & $-20 \%$ & $0 \%$ & $0 \%$ & $-13 \%$ \\
\hline & & $0 \%$ & $0 \%$ & $0 \%$ & $0 \%$ \\
\hline & \multirow{3}{*}{$\begin{array}{c}\text { Energy } \\
\text { cost }\end{array}$} & $0 \%$ & $0 \%$ & $4 \%$ & $-4 \%$ \\
\hline & & $5 \%$ & $0 \%$ & $2 \%$ & $-2 \%$ \\
\hline & & $10 \%$ & $0 \%$ & $0 \%$ & $0 \%$ \\
\hline & \multirow{3}{*}{$\begin{array}{l}\text { Operating } \\
\text { cost index }\end{array}$} & $0 \%$ & $0 \%$ & $0 \%$ & $-10 \%$ \\
\hline & & $1 \%$ & $0 \%$ & $0 \%$ & $-5 \%$ \\
\hline & & $2 \%$ & $0 \%$ & $0 \%$ & $0 \%$ \\
\hline & \multirow{3}{*}{$\begin{array}{l}\text { Exchange } \\
\text { rate } \\
\text { variation }\end{array}$} & $0 \%$ & $0 \%$ & $0 \%$ & $0 \%$ \\
\hline & & $1 \%$ & $1 \%$ & $-1 \%$ & $1 \%$ \\
\hline & & $2 \%$ & $2 \%$ & $-2 \%$ & $1 \%$ \\
\hline
\end{tabular}




\section{APPENDIX F}

\section{CALCULATIONS FOR SUMMARY TABLES}

Total flowrate $\quad=3,250 \mathrm{~m}^{3} /$ day

Dyeing wastewater flowrate $=1,140 \mathrm{~m}^{3} /$ day

By applying membrane filtration to the textile mill for water recovery, the whole system would be;

Dyeing wastewater flowrate $=1,140 \mathrm{~m}^{3} /$ day $(70 \%$ water recovery achieved $)$

Rejected stream sent to AS $=342 \mathrm{~m}^{3} /$ day

Flowrate treated by AS $\quad=(3,250-1,140)+342=2,452 \mathrm{~m}^{3} /$ day

Operating cost for;

Membrane filtration $=0.60 \mathrm{USD} / \mathrm{m}^{3}$

Activated sludge $\quad=0.87 \mathrm{USD} / \mathrm{m}^{3}$

Operating cost $=\frac{(1,140 \times 0.60)+(2,452 \times 0.87)}{(1,140+2,452)}=0.78 \mathrm{USD} / \mathrm{m}^{2}$

The calculated cross-media effects of the existing activated sludge system in the mill are given in Figure F.1 below. 


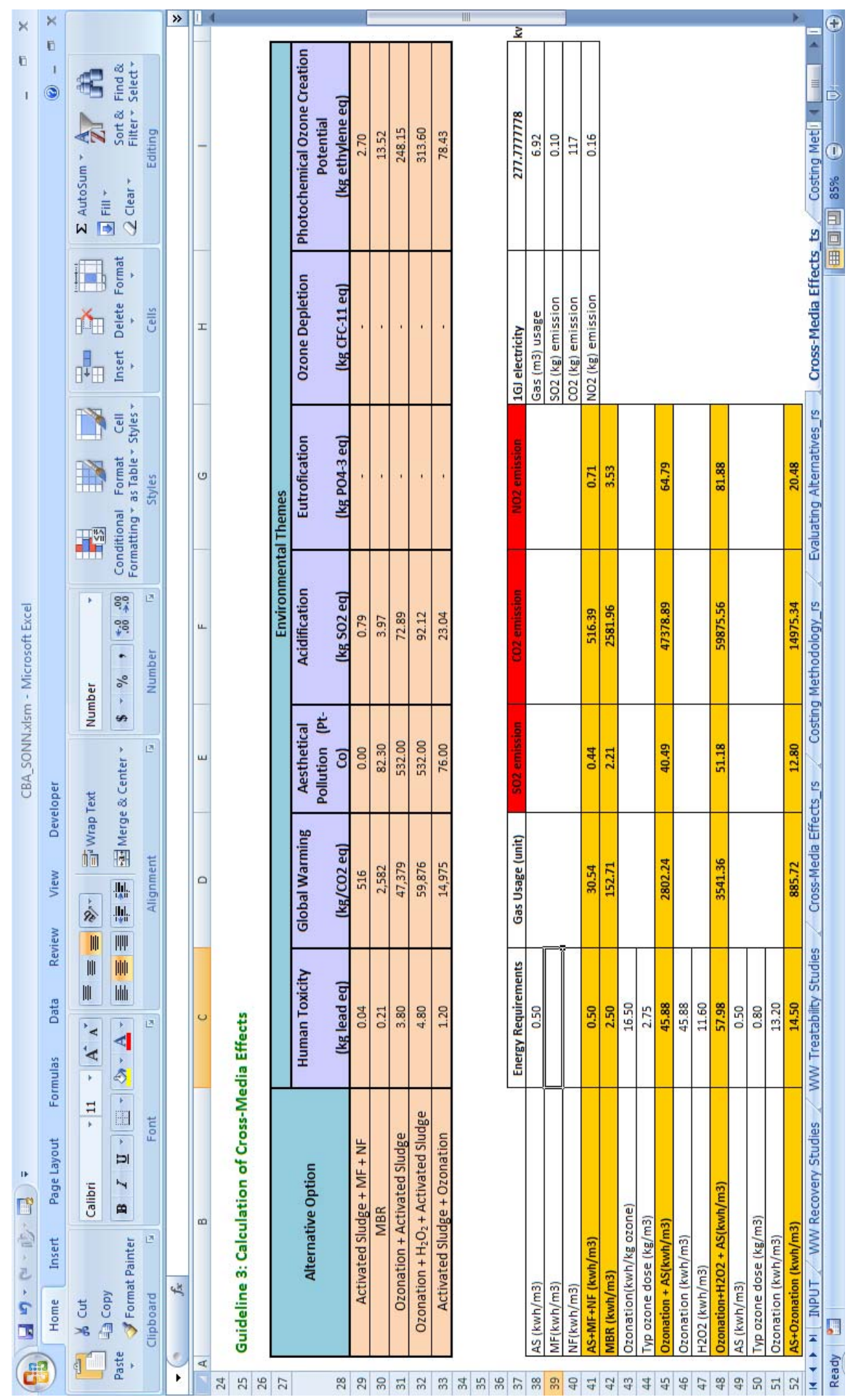

Figure F.1. Cross-media effects of the existing activated sludge system in the mill 